THE HOUSE CROSS OP THE MAYO INDIANS OP SONORA, MEXICO

A SMBOL IN ETHNIC IDENTITY

by

A. Rose Cruarine

A Thes is Subaitted to the Faculty of the DEPARTYET OR ANTHROPOLOCY

In Pertal Fulfiliment of the Requirements

For the Degree of

MUSTER OF ARTS

In the Graduete Collage

TUE UNIVERSITY OF ARIZONA 
Th1s thesis bas been submitted in partinl fulfillmat of requirements for en edvenced dezren at The University of Arlzon and 18 deposited in The Univerefty Libren to be ande evellable to borrowers under the rules of the Librery.

Brief quotations from thls thesls are allomble without spacial partesion, provided that accurate ecknowledgersat of cource

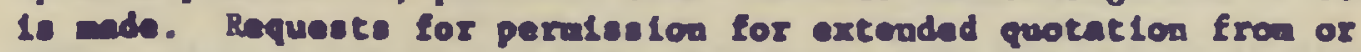

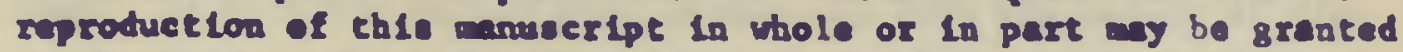
by the heed of the anjor dopartinet or the Dean of the Graduate Collere when in thelr judgewent the proposed use of the naterial 1s in the Interects of seholerahlp. In 11 other Instences, homver, pernision mat be obteined from the author.

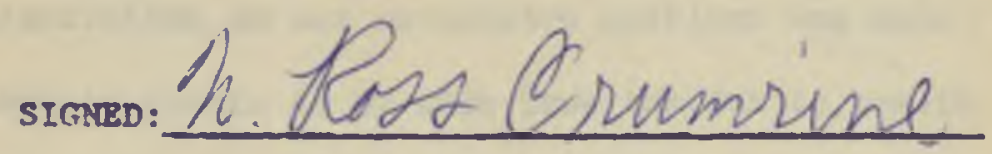

Th1s chesis hes been epproved on the dete shown below:
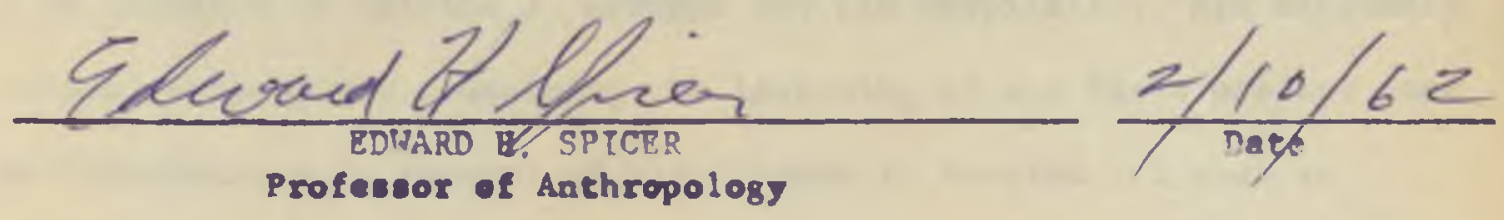
PREFACE

Thlo study developed frow fleld research done by gyeelf and wy wife In Sonore, Maxlee, anong the Mayo Indlane of the loner Maye RIver Valley. We worted as a teen, which was eopeclally helpful because much of Maro cerwonial partielpation is eex based. Often she would asecclate with the wom's group whlle I assoclated with the wa's group. In thle way we enw may cerenonles from two polate of view. Wlehout her constant enceuragemant and Intelleetual companionship thle otudy alght never have been ecopleted.

Full tim concentration on our respective probleme we ande peesible through fellewehlp grente to wy wife from the Public Health Service Instleutes of Hental Health and the Soctal Selonce Research Counc1l. I wioh to express ay epprecietion and gratitude to these two Institutions for whing thls study poselble.

For his advice and ald I an eopeclally greteful to the chalrmen of w thesle comltece, Bdwerd H. Splcer. And for thelr careful roedlas of the sanuserlpt and helpful suggertions I also grateful to the other nabers of the comittee, Bdward P. Dosler and Clara Lee Tanner. I an Indebted to Charles J. Eraowe for bie hoopltallty, his extrumly belpful suggestlone ccacerning the launching of our fleld profect, and an Introduction to several of his friends in Nerojoe. I wieh to exprese tbenke to Murlel T. Painter for the avallablilty of her unpubliohed eterialo on Arlzona Yaquis and for the etluilating effecto 
of chate with her.

Moet of all I wish to express our thanke to the people of the

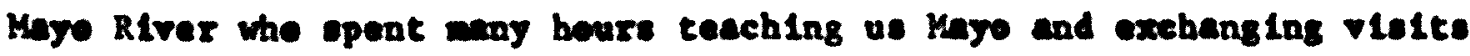
with ue.

This study by $1 t 8$ very nature could not hepe to consider all of Mayo 11fe. If the reader deslres a wore complete sudy of other anpecte of the culture, Ralph l. Neals' ploneerlng ethnography, The Conteceray Culture of the Chite Indlens (1945), daserthes much of Mayo ilfe in detal1. The works of Edward H. Splcer, espectally Potan, A YequL V1llage in Sonora (1954) and Pascue. A Yequi Vlllage In Arizoma (1940), analyze the major Yaqul cultural form and manings and thelr Integrations, in the context of the political, economic, and religlous organlzations. Inasmuch as the bulk of Beals' materlal came from the Navojoa area, and Spleer's material is Yaqui rather than Mayo, some differences w11.1 he apparent hetween my account of the Huatabaspo area Mayos and the Mayo and Yaqul materials of Beals and Splcer. Howrver, In speaking of the overall pattern of 11 fe Mayo and Yaqui cultures and socletles have an enormoun resemblance to one enother from the anthropologist's polnt of vlew. 
TABLE OF CONTENTS

Page

PREFACE......................................111

LIST or TABLES $\ldots \ldots \ldots \ldots \ldots \ldots \ldots \ldots \ldots \ldots \ldots \ldots \ldots \ldots \ldots \ldots \ldots$

LISt of rLLustratrons $\ldots \ldots \ldots \ldots \ldots \ldots \ldots \ldots \ldots \ldots \ldots \ldots \ldots \ldots$

I. Introduction, ..................................

Fleld Procedure.............................2

Maye Vorde...................................

II. THE SEARCH FOR CRITERIA OF ETHNIC IDENTIFICATION. . . . . . . .

The Problem...............................6

Two Other Pepers Concerned with Ethule Identity..........7

The Specif1c Probles of Kayo Ethnie Idontiflcation........11

Phystenl Type...........................12

Som Spectfle Item of Material Culture:

Howne Trpe and Drese.....................13

Language. . . . . . . . . . . . . . . . . . . . . . . 17

The Croes as a symbol of Mayo Ethnic Identity......20

III. KURUSIM AND TEBATPO KURUSIM.....................22

Types of Ruruet. ..........................22

The Small Palm Crose.......................22

The Roadulda Crose to Mark Plece of Sudden Death....22

The Church Crose.........................24

The Pastrela Renade Crose...................25

Pueble Crose and DIviston LIne Crese............26

Cemtery Crose............................26

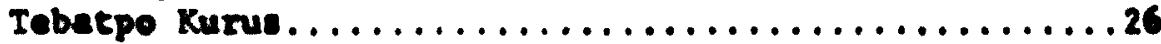

Hypotheste................................. 31

Areas of Concentration of Tebatpo Xurus in............32

Alwos and Upriver Areas................... 36

Nevojea Aree............................ 38

Cohulrimpo, San Pedro, Bechojea Arese...........40

Huatabempo Area. ........................42 
IV. SOCIETAL AND WEALTR CORRBLATES OF THE TEBATPO RURUS.......46

Matertal Wenlth and Inotances of Tebatpe Kurualn. . . . . . 46

stgalfleance of Leentien of Houses.................. so

Socletel Correlates of the Tebetpo Rerus.............53

Soclal Partielpation.....................57

Haye Behoviorsi Patterne...................60

Mayes' Ident1flention of Others...............62

v. THE CULTURAL CORRELATES of THE tKRATPO kURUS...........64

The Tebatpe Kurue LInled to Cerenonlel Reallt1ee........67

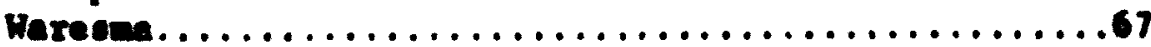

Sante Karue Cerveny at Nevounate..............7s

Bapiritu Santu and Santiden TIniren Cerensales.....77

Sen Jean Ceremendes.........................78

San Igacale Cerenealee.....................80

Todos sentee Ceremontes......................80

The Cross as 'Iter 'Alal. ...................81

The Tebatpe Kurus as in Inportent Aopect

In Several krye Ortentatlone.................83

The old People.........................83

Cermonlal Laber.......................84

The Paskole Arte and Pakko-Giviag .............84

Supernaturel Power.......................

The Lend and the Cult of the Dead...............

vi. concuusion. ...............................88

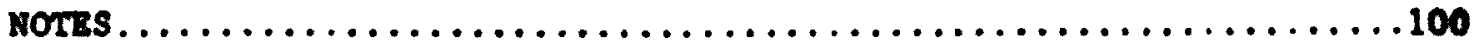

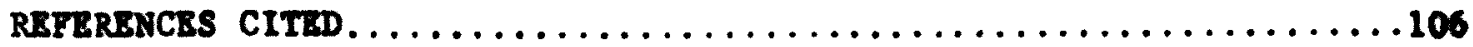




\section{LIST OF TABLBS}

Table

1. A Cemparteen of Phowente Differences Between Som Mayo and Yequl Worde...............................4 


\section{LIST OF ILLUSTRATIONS}

Plgare Page

1. Censtruetion Datalls of Tro Types of Mrye House Crose.......28

2. Typteal Lajouts of Church Crose (a), Peolopla Ranade

Cress (b), and House Crosese (c and $d) \ldots \ldots \ldots \ldots \ldots \ldots \ldots$

3. Hays River Valley Peoblos Mentloned in Taxt..............33

4. The Sacred Ways of Wareana: Jupar1 Pubb10, 1961...........70 


\section{ABSTRACT}

How cen a Knyo be recognized? What does belng Hoye man to a

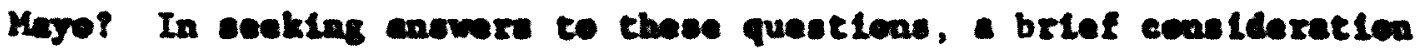

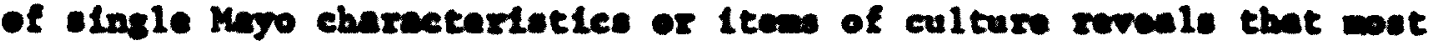

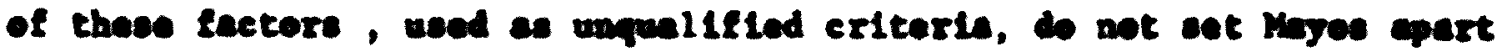

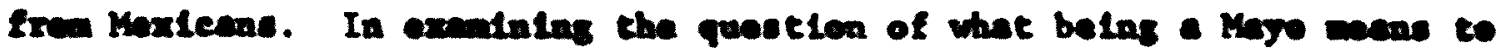
a Maje, It becane obvicus that even though the Kayes obare a

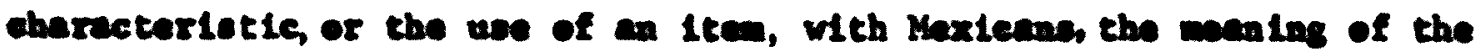
Item or ebaractertetic and Ite integratien a a eybel in the Maso

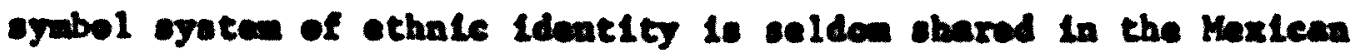
maning and integratica.

Thle realiactea et111 does not provide eny elple wethed for the catolder te Identify Hayes, but it does abow that any alngle Iten or exoup of ltem, in orcer to be useful in a etudy of ethnic Lentiflection, anct be moningful in term of the Hys oystem of ethnie Ldentity. Since mary fors of the crose secued frought with waning for Mayos, Inotances of It in the lives of the people of the Maye RIver Valley wre carafully obeerved and catalegued inte eleseas. Through

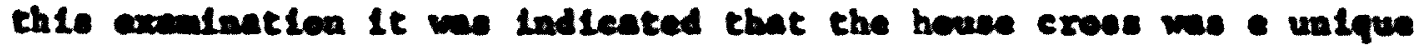

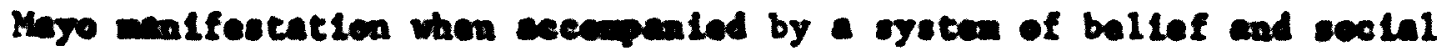
partielpation.

The date frem a general survey of the river valley are canlyzed to ohw that dence areas of boues crosece do in fect cerrolate vith the 
presence of Mayo cerouonial centers. Then date on several fandliee are enalyzed, dewonetrating that the materlal wealth of the foully hes 1ittle corraletion with the exletence of a house erose, and conversely that Mayo soclal participation and cultural behavlor correlate wth the exlotence of a bouse cress. Finally the cerwoulal contexte, functions, and 1 Inkages of the house ereas are exenined in order to describe the Maye maning of the house cross and its Integration in Maye life. Through this deseription the general character of the Maye ethnie ldentity oysten manges. In the conclusion I suggest that kayo

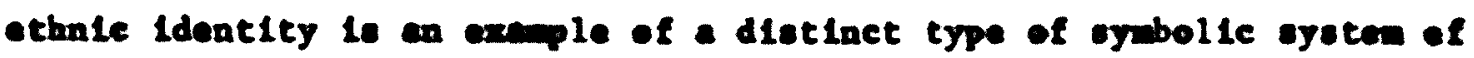
ethnic Ident1ty. And the ethnie ldentity oystem of several sroups, Tobe Batak, Mennovite, and Maspokte, are excilnod, comparad, and contrested with the koye ogeteo, reoulting in the tentative proposel of several typec of ethnle 1dentity eyotema. 


\section{INTRODUCTION}

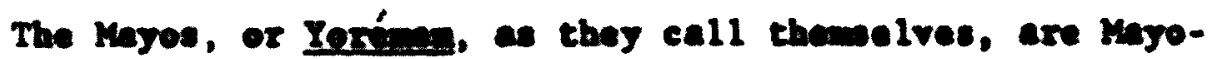

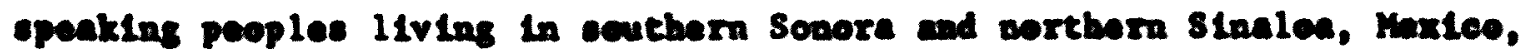
aloas the lower vallege of the Haye and Fuarte Rivere. The climate in the lemer Hore Valley, ware the fleld work ea wheb this poper is

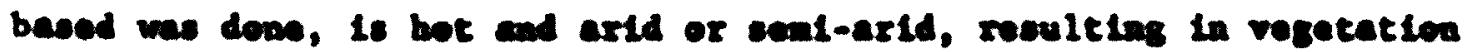
of the thorn forest type (Gentry 1942: 27) and farther domatrun, of the littoral type (Reyes 1957: 32-36). Kayos grow crope the year around with the ald of Irrigation by river weter, or sensonally with weer from the sumer or winter rains, auch leas certain weter expply. Sem Nayos are mabers of elldee (Spenlobiagrarlan greupe whlch hold and farn lands). Maxy of these as wall a not otber Mayos work also we Larm laborers. Flahing in the Culf of Callfornte is another source of food for any Mayoe. Thelr standard of 1 iving is $10 \mathrm{w}$ compared with that of farm laborers of the United states. But it 10 high whon compared with that of Indian comanitiea farther south in Mexlce, as Mayos themeelves polnt out. Mayou live in sdobe or lecal (Span1eh: type of wattle-and-daub) bouces, and wear sorts of elothos sinilar to those worn by farmers and farm laber in the Seuthwestern Untted states. Som om bicyeles and redios and bre electrielty in

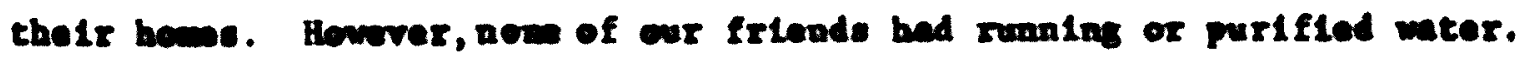

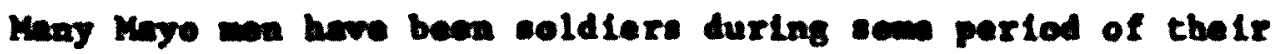
lives and here platted a great deal of Maxice in this way. Mast of cur 
male Mayo friende conld read and wite som in both wayo and Spaniob, oren chough thay bad not gowe to achool looger then eaverel monthe or at the wet severel yeare.

Early in the 1600'. the Mayos were aleslonlsod by nombere of

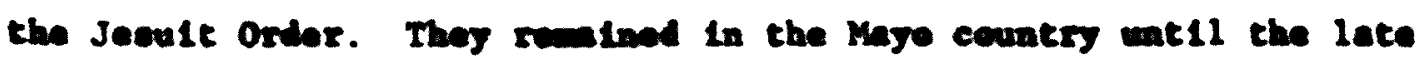
1700's, when they wre ropleced by the Franciseans. At the present tim

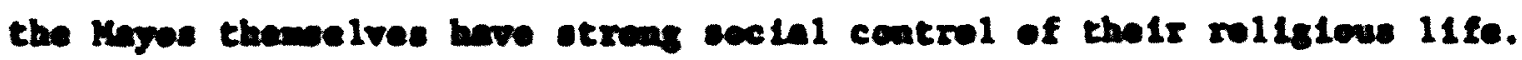
A grow of Mayo ley alalotere generally hadles the rellglows eorvices,

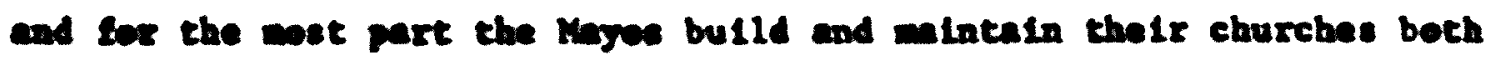
physically and opleitually.

\section{Field Procodure}

In Hovember, 1960 wife and I took up resilence in Nevejoe, Sesorra, Maxico, where w I1ved unt1l March, 1961, when we woved to

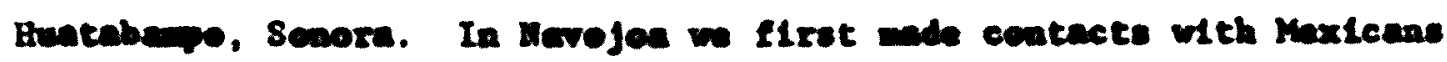

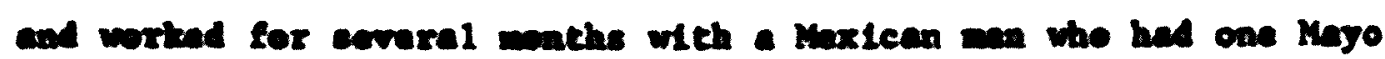
parant. He was aploged by us as a gulde to the rage valley end on ecreral cecastona to the ruerta valloy.

Aftar survoying the area we elocted to work farthar down the riv-

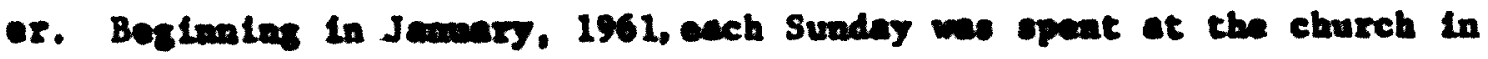
Juparf. Fortuantely ane of the church officlalo wes will lng to apend

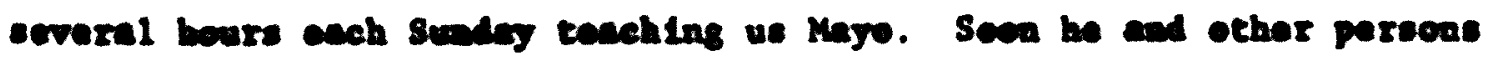

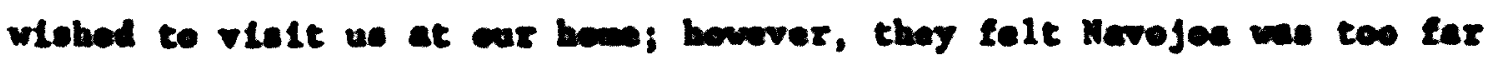

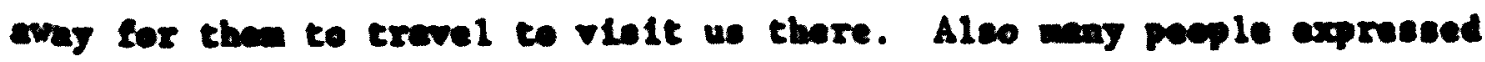
the opinion that we obould elther attend church in the Marojea area elece wo I1ved there or nove to the Huatabampo exea. So In March, 1961, 
westablishad residence In Huttabepo there w 1 ived unt11 the aldd of December, 1961, then we returnad to Theson. The fleld pertod we broten with four tripe to Twesen for 1 bbrary recearch and discuselea with our edviere.

Oar procedure we to learn and we the Kaye leaguege and threugh the lesralng of the language to learn the culture. We also attonded all the Juparl church cerementes that wre open to us, and wro eften lurited to cerwmalee at otbar puobles nar Juparl, some of whteh were able to attend.

In order to erente wore doptb in our date we becen close frionde with a fow featiles. A sabodule we eet up and esch wek wo pletted

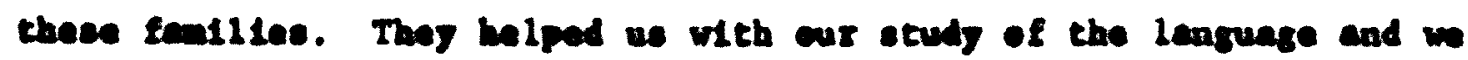
ehntted. Nowe of our friende wro peld. Hourver, sceording to local

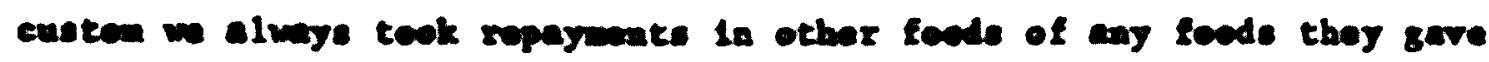
us. We ales leat onll oum of mongy and gave rides in car truck. In the latter wothe of cer fleld work may of ent friende were vieltias our bew regularly to learn English and to chat. In termo of our particuler studies we felt this procedure produced eatlefactory reoulte.

\section{Mase Worde}

Several Mage worde hure been Incorperated lato the body of chis paper. The orthosraphy used for these worde rery clocely epproxtantee that aplalme for Yayul in The Phowelor of Arlzone Yeaul (Cruarine 1961 ).

The Kayo and Yequl leaguages are quite ofinilar; however, phonate and worphemle differvees do exiet. Sem phonemic differences are shewr in the following exomples: 
TABLE 1

A COAPARISON OF PHONEMIC DIFTBRENCES

BETWEEN SOAE MYO AND YAQUI WORDS

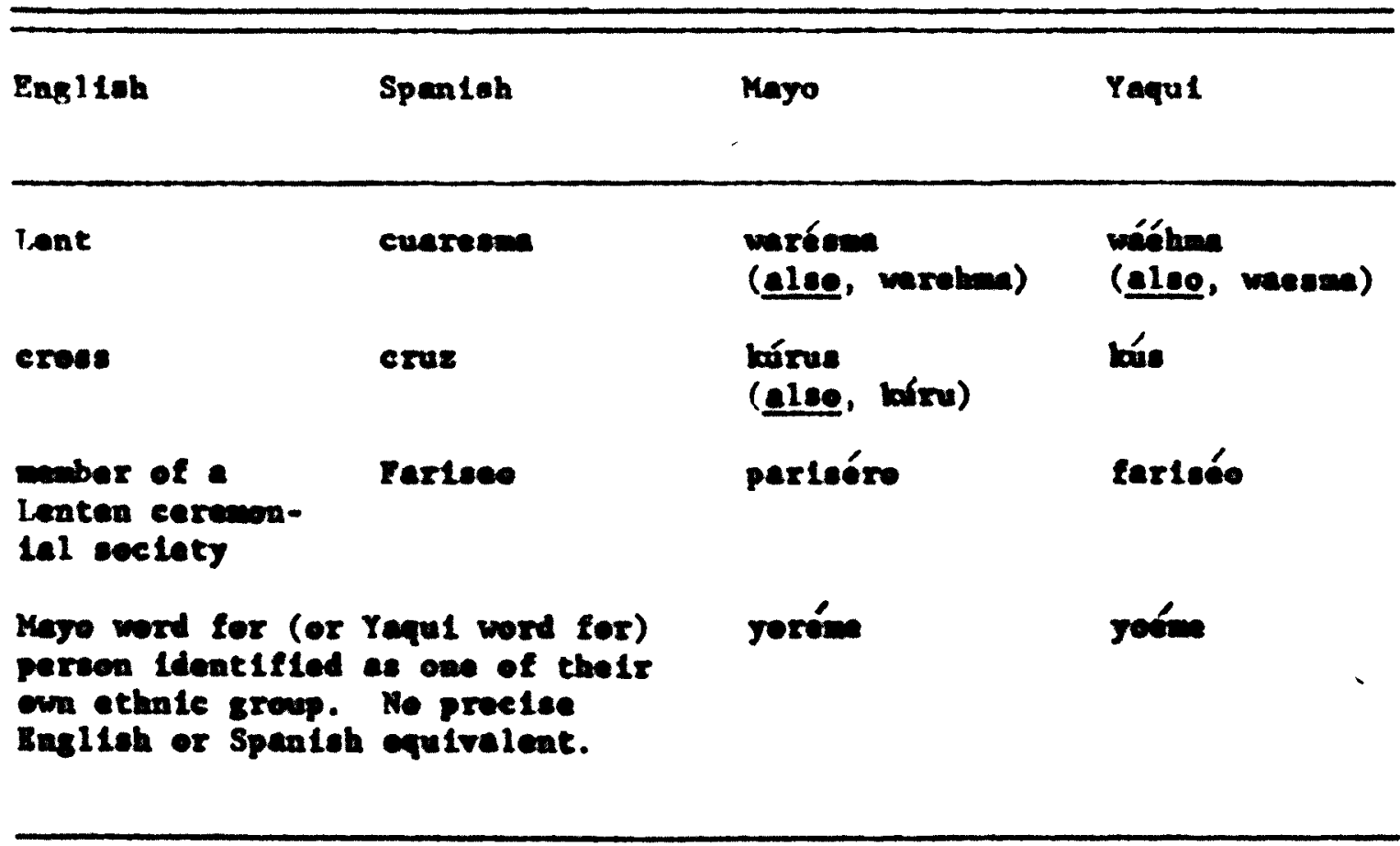

There are occastenal differences in strese and tone in cognate hayo and Yequl words, and in worls which each lenguage bes berromed from Spenish.

In thie paper a Kaye or Spanish word 10 martad bor etrese and undarlined only the flrot time it eccurs in the text. Mayo worde are pluralised by adding -e to words onding in a romel and - in to words

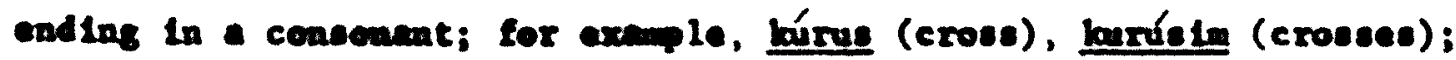

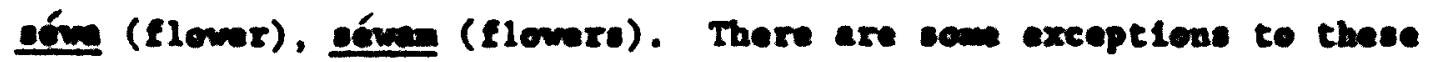
gonaral rules, for exaple, 'alowíst (lowet ranking ceromonlal beat),

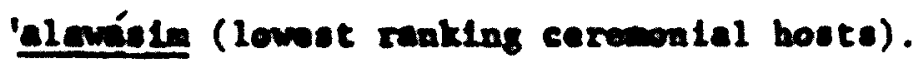

Also I should 12 te te note that the opelling of the now of the pueble of Havomaxla (phosentealiy opelled it muld be naboníkela) 10 as 
1t eccurs on the Sante Kurue flag of that pubblo's church. I a epelling patóle (Maye cermemial dancer) with a I rather than the E of the Hidpanic epelling, olnce I en endeaverlag to epell all Kayo wrde I woe here phonouteelly exeopt for plece nome. 
II. THE SEARCH FOR CRITERIA OF ETTNIC IDENTIPICATION

The Problem

Since anthropologlats have generel'y been interested either In preilterete pooples or in emil commonities as woles very little has been written concerning processes of ethnic identiflention with the ethnic sxoup or othera' Ldeatificetion of the group. The firat problem facing any athropologist working in a eubculture of the natleas of today to the identification of nubere of the society he plane to otudy and of Individusls who share cultural maseninge and aymbolic form. Many copuetutances wainglese in term of the field project and wech lost fleld tim could be oreiled if some inple method were et hand to delinente the fleld of ebearvetion. Our experience bes been, boverer, that ethnic Identificatien as en enthropological problem is wore maningfully thought of as a procese of beconing avre of another culture and another eymbol eysecen. By ethnic identification is want the mechentom by which individuals recognize members of their oun or of another soclal group, and by which they recognize persone sharing or not aharing a culture and eymbel oyetem. In other words, In our epecifle case, how does a Maye, or an enthropologist Interested in otudying Maye society or culture, recognize a parson as Mayo or Mexicen? Or does any real baels for identification exiot? Is it parhepe only a contimuu Iltw thet frow ricb to poor, for exemple, or from country to townopeople? One espect of this problem is the overlapplng or sharing between socteties of some soclal orgenteations and cultural bellefe and values. 


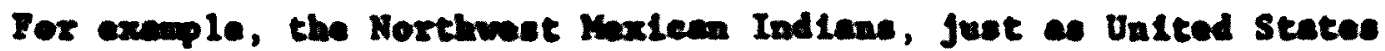

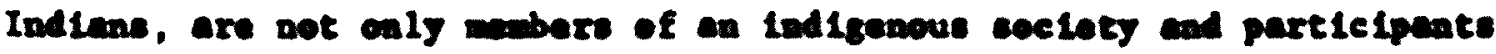
In Ito culture, but thay are alco eltizens of thelr reppetive countries. They often past Spentoh or Bnglioh es wil es thetr

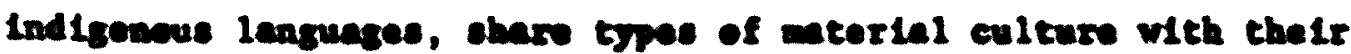

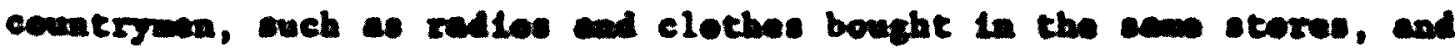

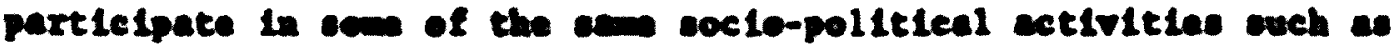

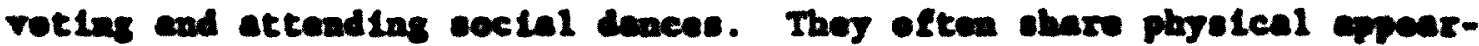
ences a well.

Two Othar Pepara Cencorned with Ethoie Idontity

To Dorothy Libby in bor article "Three thendred Yearo of Chebeht

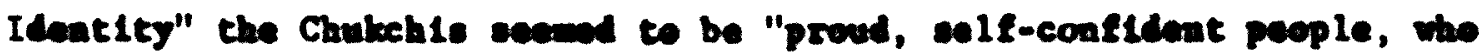
felt themelves and thelx wy of 11 iving to be differont from thoes of ether peoples" (1960: 298). This seoned to we to be true of rajoe alco.

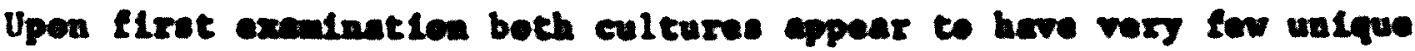
Item, we of which in asch eage 10 a dietinetive though constently

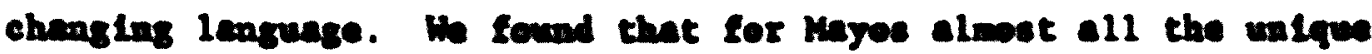

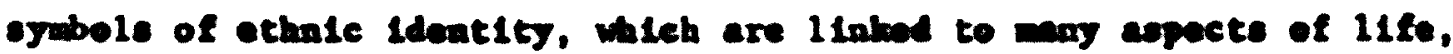

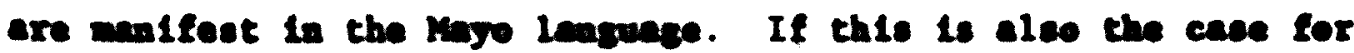

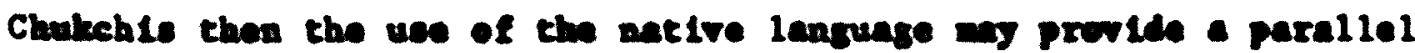
between the two esees, in the etructure of ethnie 1dentity.

Llbby antloas that Chakch1s ot111 feel a eparatenese of

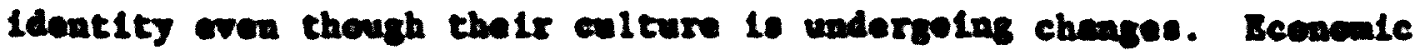
chenges eppeer to be the noet repld and "In the realn of Idaes, ett1tudes, and bellefe there is leas obvicus ehenge" (LLbby 1960: 299).

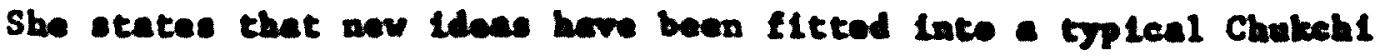


wrid view. For example the sun, to whleb secriflese used to be made, Is now likened to Lenln or Stalin.

Mayo culture has undergone and 18 st1l undergoing changes, espectally in the econonic reale at the present $t$ lwe. Many of the now ldeas are edapted to flt Mrye world vlew, At some the after the niestea perlod the sun, wheb wa probably a pre-Spenish delty, becene Identifled with a Catholle Christ. This procese of cultural fusion has parallels, then, In both Mayo and Chukchl cultures. Also relatively old culture patterns et111 reanin in both cultures, for example the curlng of diesese by native curers, shamens for the Chakchls and hltol Loe (Mayo: ahomballke curers) for the Mayos, alde by side with newar practices.

Libby concludes her arelele with the Idea that "this feeling of ethnic ldentity was not depeadent on ung particular manifeatation of Chukehl culture, but that in pert it we depandent on their om bellef Ln 1t" (1960: 301).

The bellef of a group in the abselute unlqueness of their am sybols representing themselves is definitely en important appect of a people' thinking bout themelves. A study of the Implieatiens of Libby's statewent in apecifle cultural context shed 11ght on the foundations and structure of such a bellef. Only after a minlmum of Ix months of Intensive participation In Mayo society and culture were we slowly becoming fully aware of apects of Mayo culture which had becom sacred and ends In themelves, such as using the Mayo language, wearing andals, belng poor, and having a house crosa. In many way the Mroe are not different culturally or socielly from their Mexican 
nelghbors, but in the creation of sacred symbols from selected anpects of 11fe and in the unifylng of these aymols in a bellef In thalx oun ethnic identity they insist they are truly unique and very different, especlally from Mexicans. The intent of this peper 1o to denonutrate that the Mayo bouse erwee (tebltpo kírue; tebltope, on the pat1o, and kírus, eross) Is not oaly one of the wost cestly observable symbols of Maypo ethale Identity bet also coe that 18 Integrated with way other aymbols. Thus en underatanding of the tebatpo burue leade one doep Inte the Mayo oyoten of ethnle tdeatity.

w1111. Sibley In the article "The Malntanance of Ualty and Dlotinetiveness by a Phllippine Poasant Vlllage" coneldere the soctal aspects in Fillage Llontity (31bley 1960: 505-512). Many of the

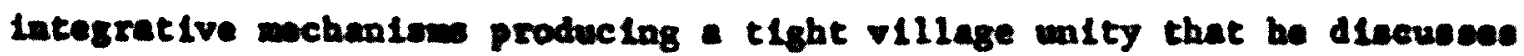
appear aleo te be operating in the Maso v1llage of Jupari. The

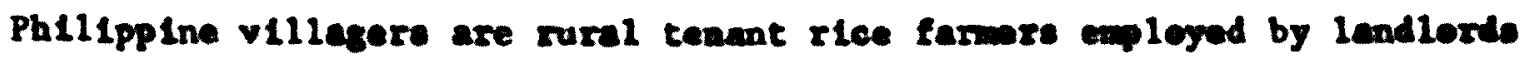
who live in the citles. The Magee ueually elther tarm ejldo land or work te farn laborers for landlords living in Heatabepo, the large com nearby in the lown river valley. As the Philippinos leave the village flrat to plant and then to harvest, some Mayos also leave seasenally to fish on the shring boats or to plek cotten, chiles, or frult, scometess golng as far as the United states. However, nelther peoples appar to be any $10 n g$ enough to deotroy the1r 1deas of ethnic and pillage 1dent1ty. At least thle is true of the Mayos in know. In years past a great deal of Mayo village unity way have been lost through way goers of wax and service in the orndes, deportation of wany of the mo, and infiltretion of Maxicans, but todey the feelling of ethale unity lo increantas 
arag Mayos.

Sibley also discusees the yearly patron salat flesta whleb he conslders another unlfying factor, at it also Le for Mayod. Howner, It functlons, In aditlea, on a mech wider seale for Mayos. The complex religlous observenees during Lent and the firot of November cerve as pueblo or aree-unlfying factors. Dering these thes each pueblo wth lts camtery, chureb, and surrounding countrytele, are unifled In thelx rolation to thetr an dead and to the death of Christ. During the patron salnt cerwmonlee may Majos are unlted, es for exmple, In the ceremony for Eaplritu Slntu (Mayo: Holy Splrit) of Etchojoa. In

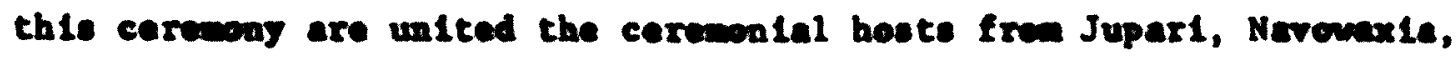

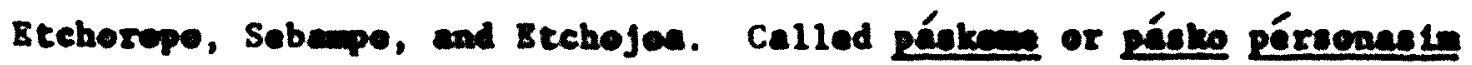
In Mejo, these hoste denste geods and serv1ces, orgenize the cercmony,

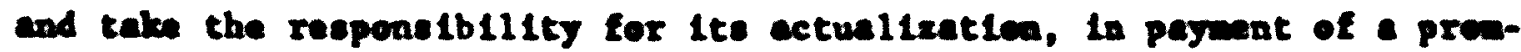
1.e mode to the oupernetural whese cercuody they are giving. 1 The ehureh ergenizetions and congregatleas are also unlted through these ceremonles. The ceremeny for Sentíle Tíntren (Maye: The Hoot Holy Trinity) unites not enly the peskene groupe from Etchojon with these of Jupari and Nerowarla, but alee bringe kayes fren the kyye and Fuerte Rivere who have promlece to attend this cerveny. Speciel ceremonlal exchenges of bresd and certmonial equipunt betwen pastom from different pueblos mphes 1se unity and essure goed heart on the part of the unlted percons. Thusly the cervmonles and religlous observences unify not only the pueblo and countryelde nearby but alse unlfy. Yoremen from both river valleye.

$$
\text { Since the roligleas life functione alse to link Maye villages }
$$

with one enother, as wil as the Inhabltants of the village with one 
another, I bave conollared kayo ethole Identity on the oupre-rillage lovel primarily, and have elected to discuse one of the eymbols in Mayso ethaic ldentifieation overywhere, the tabatpo borus, which will be shown to fruction at one of lts pervasive symbols.

The Specifle Problea of Mayo Ethnic Identifleatiea Upon arrival In Mavojan the first and nost preselag problem was one of defining a field of obearvation. Who mere Hayos, how could a etranger Idantify thea, and just bou could a unlveree be deflend In terw of the Mayo population were the questione that imadlately bocan inpertant. Since one of eur ebjectives we te galn an understanding of the Mayo leaguage it wa necessary to be able to 1deatify not only a Mayo but a Mayo who opoke the language woll.

The firat and wost obviove method was to ask people, "Who exe Kayoe?" ox, "Aro you Mayo?" We proceeded to alk cur Maxican acqualatances about Mayos and recelved enowere such an, "We bere are ell Iodles Kares," or, "There ts no diffarence between Maxicans and Mayee; we are 11 one people," or, "Host people In Navejos bave ecen Maye blood and many spoak seme of the language." It was apparont then that tom Maxicane held an Ideal pattera coneloting in a refusel to edalt of any ethnic difference. Howner, we 2100 heard unguarded

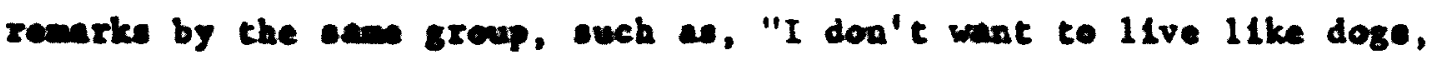
ilke Indiens," so tt was cleax that confileting petterne existed. Statements such as the precediag assume som feelinge about ethrife Identity for Mexicent as ageinst Indiens. Also, it was later discovered

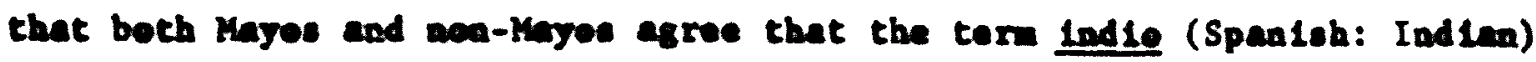
10. Alotaeteful word, and that Mayoe occesloandly use thelr own 


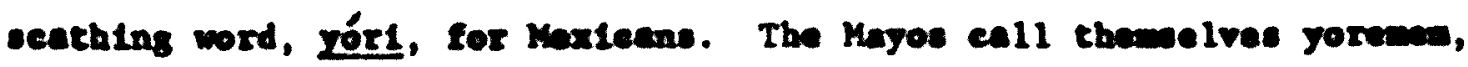

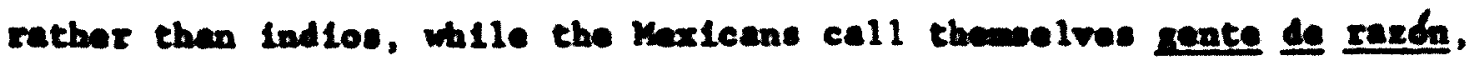
(Spentob: people of resoon). This ladicated thet in roelity an ethale

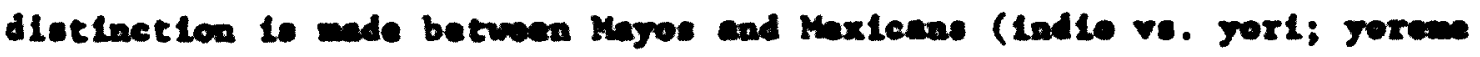
ve. gente de razen) by both grenpe.

It we apparent that Mago ethnie Identity could not be found in

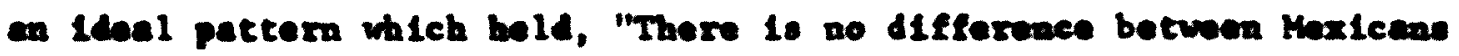
and Nisjoe; we are all on poeple," thus retuelas to chate oponly an

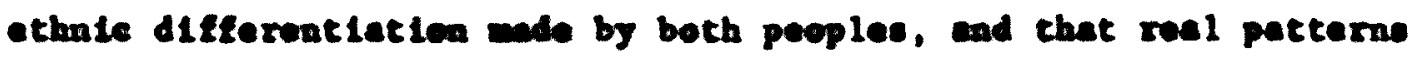

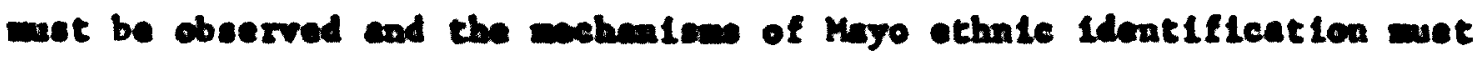
be abetracted from obeervable roelities.

\section{Physeal Type}

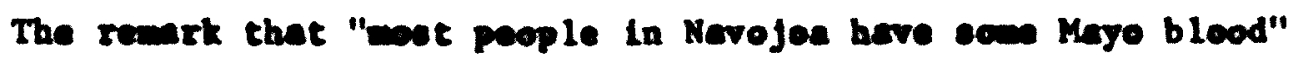

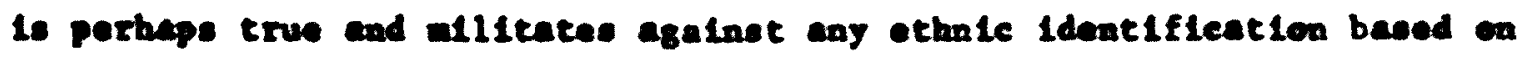

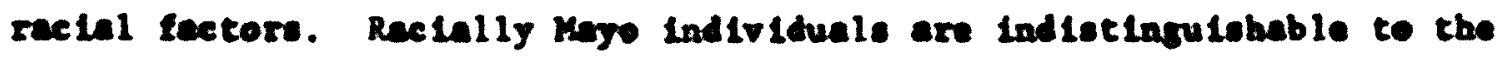
ore frem tbals Maxicen nolghbors or from Indiano orlelnating farther ecath and now working in the erea. Taken as populatieas some opecifie phyelenl tralts aight be found to detinguish, In etetiotieal ters, a Maso from a Maxicen gene poel, but working with a culturel and

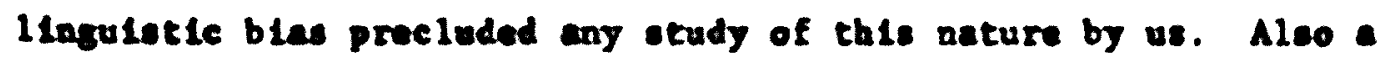
population of North Amrtesne estied In the 1870'. In the Fuerte RIver Valley (G111 1957) baee socLallatic ldealo led them to reapect and, In may cases, to becone close friende, with Fwarte River Mayos, thus making possible the addition of Nortb Amertcan genes to the Puerte Mages' gene poel. In the past there has been a great doal of inter- 
chenge of personnel between rivers so that many of our Mayo frienda were born on the Fuerte River but now live on the Mayo River. And others who live on the Fuerte come to the Mayo for a gear or so in order to work off religlous promises to santos (Spanleh: saints) In the Mayo River villages. In fact some people, when asked where they were born, w111 spec1fy, "Here on the Mayo RIver. I am truly Mayo River Mayo." Thue it is apparent that Mayos physically consist of genes from not ouly Iberlan, Fuert RIver, and Mayo River ancestors, but also from Northern European onas. Physical appearance is varted, for we knev persons, all deep In Mayo culture and soclety, som of thom could easily pass for Northern Europeans rackally, and others tho looked very dark. With spectal measuring Instruments and statistcal techniques some significant differences might be found. More important for this study is the fact that wo correlation between any obvlous character such as skin color and ethnic Identifleation was found. Often Mayos mould call us Yoremem because we could speak som of the language and participated in religlous ceremontes regularly. Or often atranger would ingulre whether or not we were Yoremen. Therefore criterion of athnic tdent1flcation besed upon observable physical characteristics was mentagless for this study.

\section{Sose Speeifie Itam of Material gulture: House Type and nress}

As we becene fenlllar with the puebles up and down the Maje River it was proposed that some aspect of house type or furnishing might be useful In Mayo Identiffeation. However, undar closer oxulnation It wae found that both Maxicens ad Mayos ifve In eltber jecal 
hesses, or adobes, hrve radlos, sinfler types of bede and cots and ether materlal objecte, than the use of ouch ltem as an Indax of ethale Ldentiflestion baced upon observable phyoleal characteriatice of thle cort was guestenable procedure. When wa intensified our centecte with several eelected fentlles a list of ltem of anterial

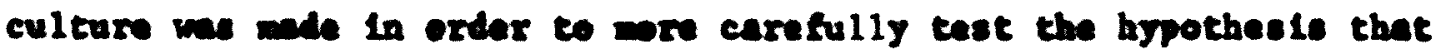
material walth wa correlated with hoving or pot having a bouse eroes.

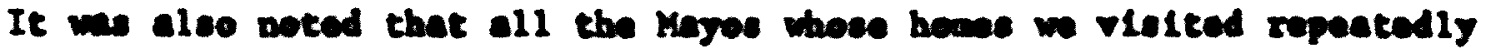
had houses, wather of alobe or jacel, thet were supported with

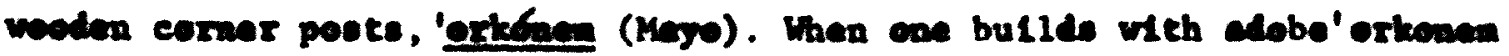
we not esecatid, w with jeenl; howrver thay are copareatly ielt

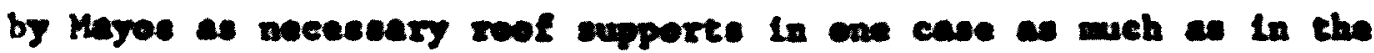

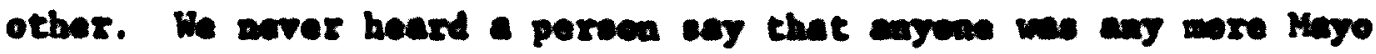

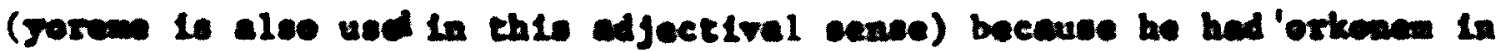
his houee. Alse fow ether 1 inkages to other Yerwe oymbolion of ethnit Ifentity could be found to beuse type and furnishinge mere given up

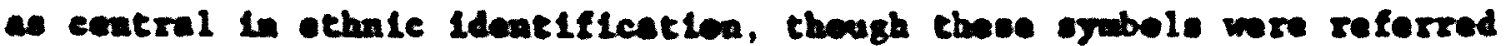
to In ettempte to ettef sen ides of people's craluntiene of the malth of opectelc funtlies.

The propestelon that elothes were a elve to ethnie lentity we exentined. The ouly ltews of kyso drese that seemed to hold any

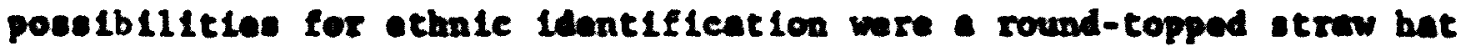

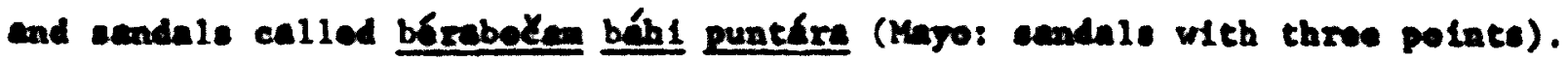
Sean of the old wn, a rers cencervative younger peolo persene, and the Jupar1 Image of Sen Juen (Spanleh: Salnt John) woer a round-topped etran bat. Howrever, as the Sen Juen Insges frow Nevojoe and Mocúsari, and 
the people who dance for San Juan In Nevojoa war the flat-topped etraw hat, typical headdrese of nearly all the Mayo and Maxican wen of the whole river valley, the ituation wa complicated by these factors. Piret, the round-topped hat is no longer in widaspread use, and secondly, it does not eppear to integrate widely with a great number of other aspects of the culture. So nothing wore was done with the round-toppad bet in termo of deseribing ethalc Identification of Mayos.

The eandals present en Interesting problen. lipon firot exriving In Navojoe we notlced a man who was identifled as a Mayo by others and who opoke oum Maye, working at one of the notele in toma and weering eandals. Thls then suggested the hypothesle that Mayos ceald be Identifled by the expectation of warlng sandels. Howner, a fow daye lecer thlo sam an wa seen wearlng a now patr of shoes. Later in the fleld perlod we were to ake frlendehtpo with both Mexicano who wore sandale and Mayes who wore sboes when golng to town or on ether cecaslone, though net kajos wore sandale on cecastons of cermanLal labor. So It was cencluded thet Mayos tand to wear eandals, but any Ladividual with shee on alght well be elther Mayo or Maxicen.

One efternoon in the warkt a conservative Mayo frlend happened to cee a man wearing shoee. Since be had been giving us Mayo worde and expreselons for cur language study our friend pointed out to us in a rather unkind anner that the other wan was waring yórtboten (Maye: yór1, deregetery ter for non-Maye; béxen, shoes or footwer). The conservative en wont on to explain that the sandals which he himelf wes weering were called berabexa bahl punters and thet they were the proper ones for Mayes to wear. These sandels conslet of a leather sole, or a rubber 
one cut frum on old car tir and are factened to the foot with otripe of leather with are Eactened to the sole at three polnte--hence the Ming now bohl pantars, or throe polnted. It is on the pattern of a thoag-type candal wth a heal otrlp. Other types of berabexa besldes the bahl puneare are worn by Kayos.

The marting of sendale and caking pride in it then, is ow of

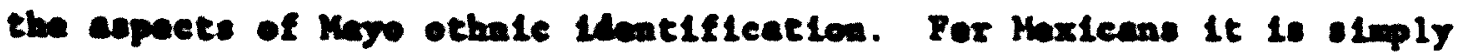
- chesp footwar wen cae exwot afferd wore expenstve shoes. But for

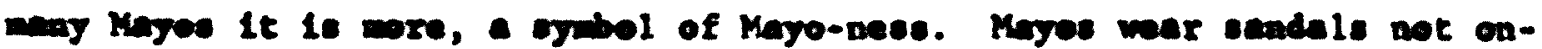

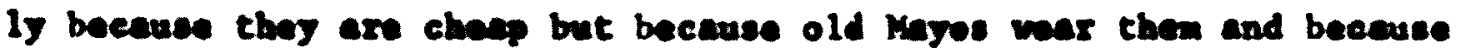

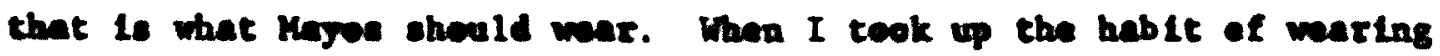
endale ceversl of our friends reoponded, "Now yea w11 walk hepplly oo the earth," polnting at of feet. An cequalutence whe hed changed, she sald, frum a wre Haxican to a more Moro wy of $11 f 0$ told us that bafore ohe begen to war candals abe had been unhappy and slck all the tim, and now, waring esndels, she is well and happs. These seadals then,

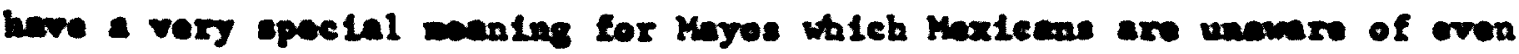
thergh they aleo war endale. Beraboten behl puters are pert of the

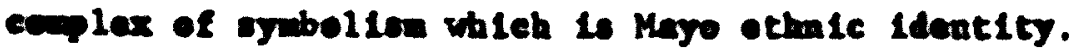

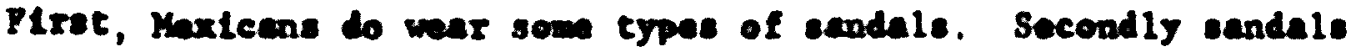
bwe little or so linkage with many other eybols iportant in Mayo ethnic 1dentity, though they are loosely integrated with 1deals of a meterinily atple life filled wth poverty and sefferine and with a health orientation. But the sandal sybol camot be consldered on of the most provocetive in Mgyo ethnic Identity. 


\section{Language}

slace ose of the firut atm of the gemeral field work of Which this study was a part was to obtain an uadoratonding of the Mage 1anguage, the bypothen 1s that the abl11ty to opeak Meyo was an eopect of Maye Identifleation was suggested.

$$
\text { Upea cur exrival in Marejoa we we a man working in a gas }
$$

otatica who eald be had opent eoveral yeare in Callfornta. He aleo elalwed to spoak Mage, though, "Kow," he eald, "I bave forgetten much Mage, but I spoke well as a recose men." Hare then wae en Individual who

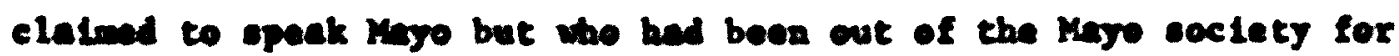
mony reare and as fax as covid be judged had sot earod to rejoln that

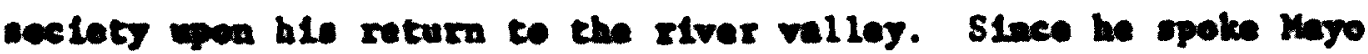
obould be be coastlered a kaye?

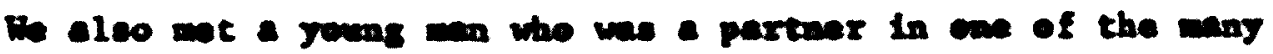
busings enterprises created by the seeds of the Horth Amrican tourlot.

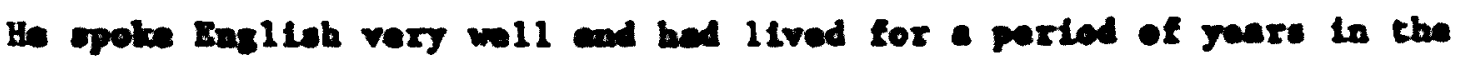
United States. Thon one doy be mentioned to wa that be could apeak

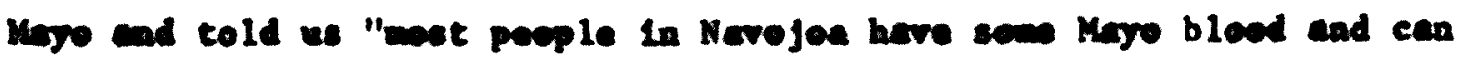

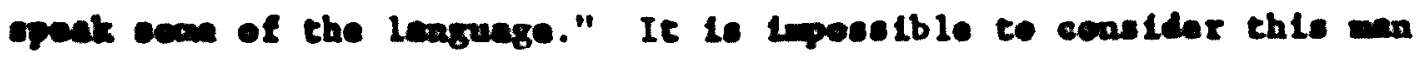

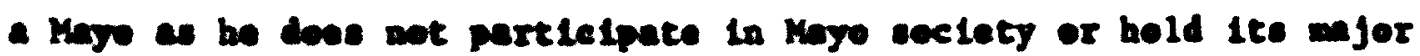
culturel values, bonver, be speake seme of the lenguage. Our next

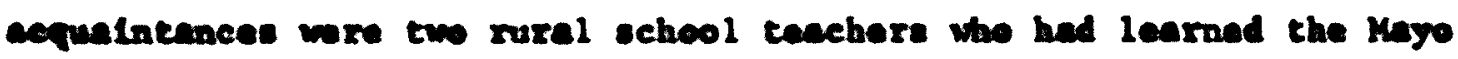
language la orlar to tecech thalr Mayo puplle spanish. Obe afternoon one of thase geve us a loag liot of mago worde. She provely polnted out

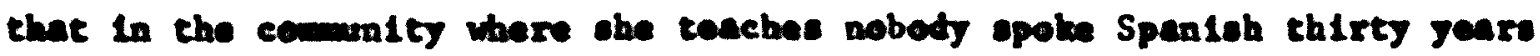
age and now very fow poople opank Mago at all and caly several elder 
people speak it wil. These teachers opoke come Kayo, but were definitely not Mayo, for thetr value oyetern and aptratteas were etrongly Moxtcen, a sor conple they ware charecterlead by a great

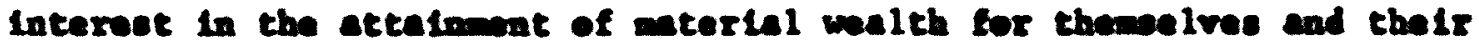

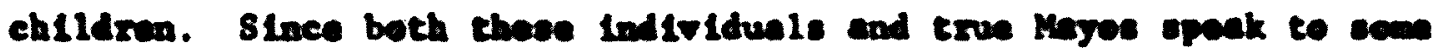
Aogree the can languape where doe the differwee 110 or does a

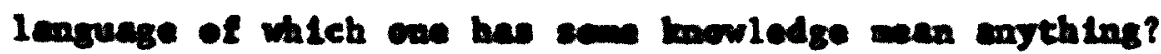

As we learned were usp it becen epporont that these

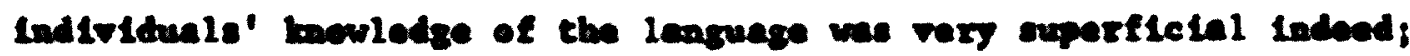

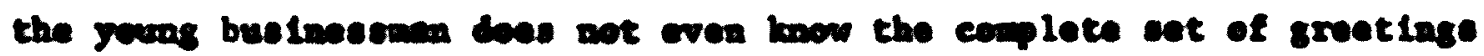

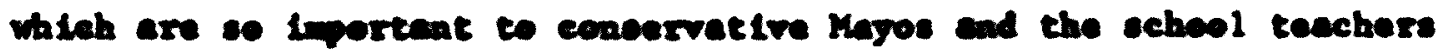

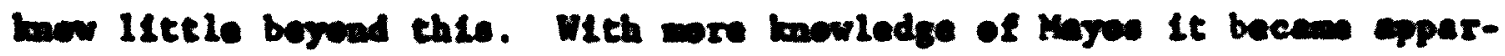
ont that the cegres of profleiency in the Moso learuage to inded related to the dopth of the Individual In Mage eviture and coelety.

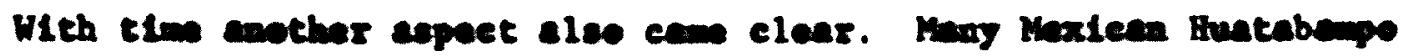

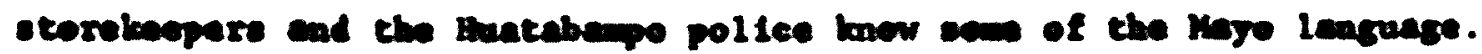

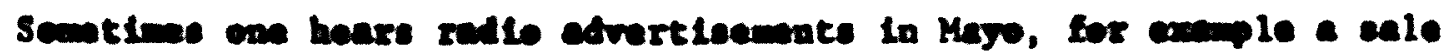
of clothes for son Juen's Des, Or can wate a Maxiem who has jeinod

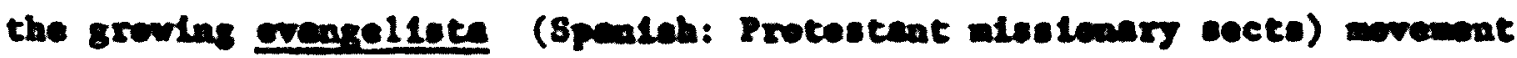

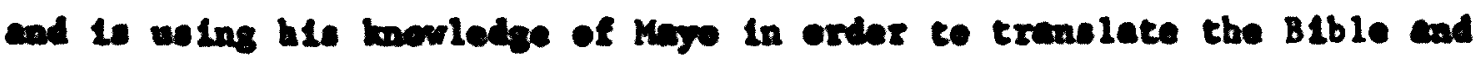

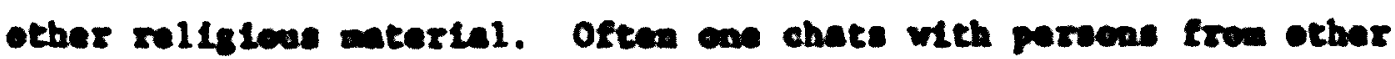
perte of Haxleo living in the river valley ad learning or epenias

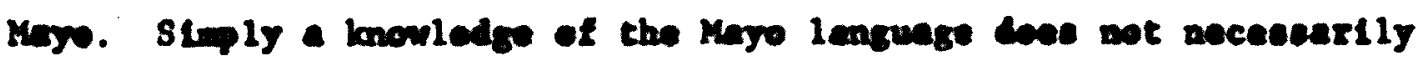

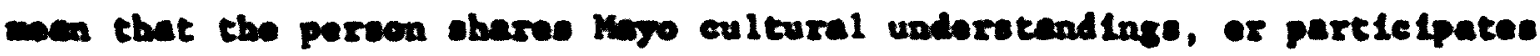
In the ecclety in senarel; boverex, a proference for opeaking Mayo over

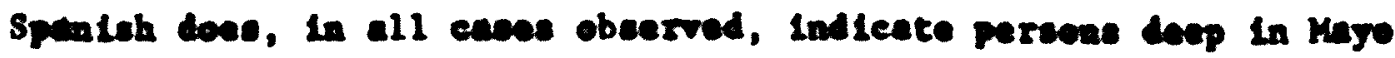


eulture and eoclets.

The ipportent appect for ethnic Lentiflestion is whet the

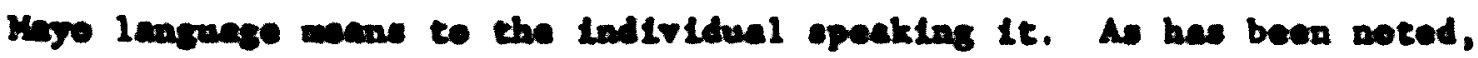

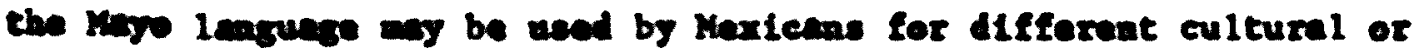

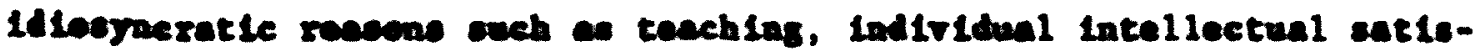
Lectleas, or for bustaces ectritles, but when a kyo woes the leagenge

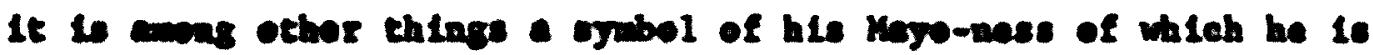

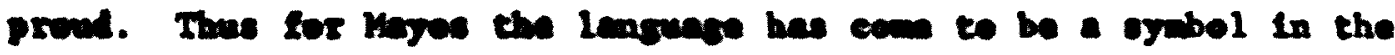

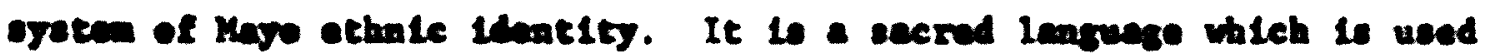

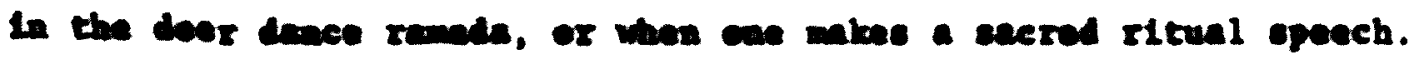

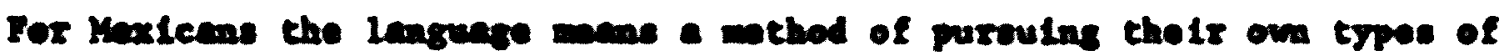

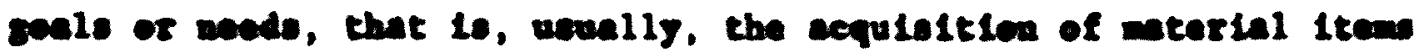

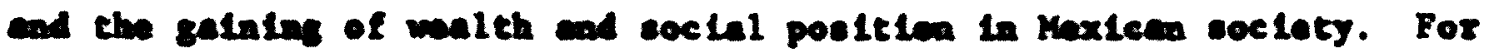

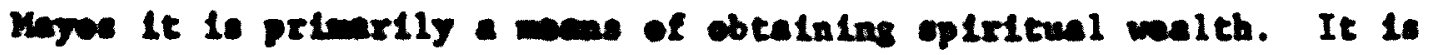

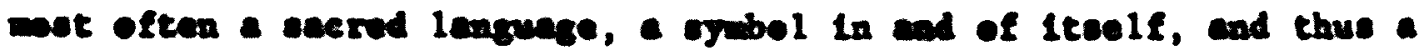

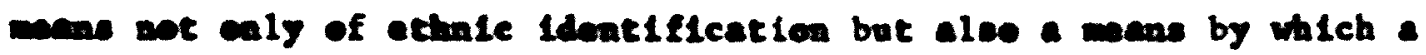

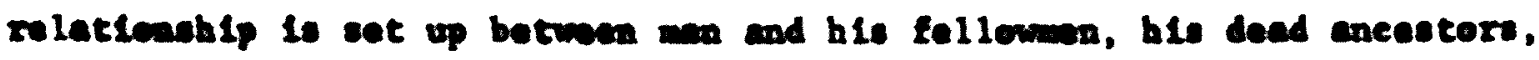
his Gode, and a mans of enjegles the benofite of the leer and pastola axte. ${ }^{2}$

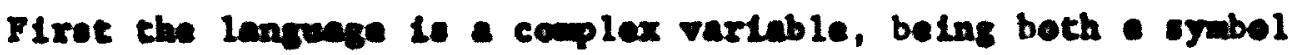
In ad of ltealf and a carrier for nearly all lf not all Mayo oymbols. Secondly, the mentag of the lenguage to the indivitual opeaker, wh1ch

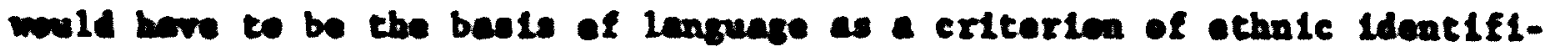
catlon, wald be a rast an procedurally complen thing to observe. Thus turther hypethese eaneerning ethole Idontifleatlon wre sought. Whech the and eort of process is taking plece in the use of 
the oymbel of language an in the case of the sybal of andels. In both cases on appect of everyley life has been rumbl late a eacrod oymbl of ethnic Identity and has been linked inte a wole, a Maso "eryotellization, from the usphous realn of feeling, of forme that are elgniflcant or aybolle" (Read 1955: 18). The Kayo-nees, the Maye ethnic 1dentity, then, It this unigue Mege "cryetalliration" which takes oharad eopecte of both Mexicen and Mojo $11 f$ but creates a deflnite and unique kyo oymol and oybol ogotem from then rather than a Kaxican oybol and aybel oyetco.

The Crose as a Sybel of Mayo Ethnic Idantity In trylng to formalate the oybollc basto of Maye ethnic ident1ty the search for a ueble central concept resulte in these findinge.

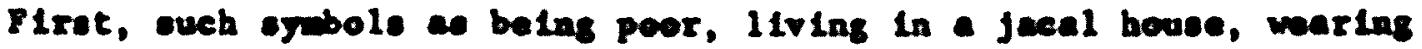
sandals, and spacklng Maye, are obared to som extent by both Mayoe and Maxicens, but they are related to the rest of life in a differeat maningful wy. A Mxicen is peor because he lo soving for the future or because he cannot help himeelf, not because he dealres to be. But a Haye io poor, he saye, because good people are poor, thus be 10 a

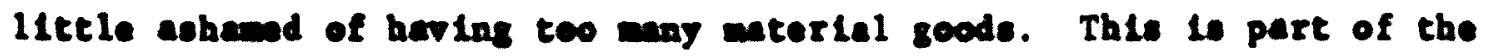
Heje concept of the world as a place of ouffering and poverty, which 1s expresesd In way cenmonies, particularly those of the cold, dry, dusty seseson of Leat, In which the euffering and crucletulon of Christ are reanacted.

Secendly, the crose appeared to be just the form and eybol for

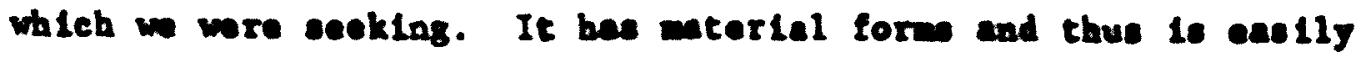


obearvable. Cresses exlat in both Mayo and Kaxican eulture, whleb my tend te creste som cenfulen due te obared form and perhepe

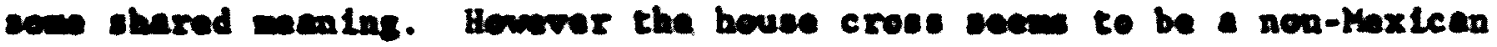
tralt and thue provides phyeleal evidence of Hajo ethale lentification.

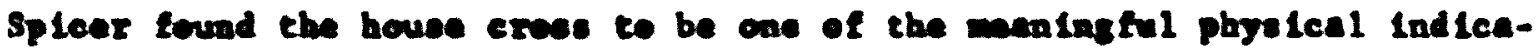
tleas in ethnic Identiflentica of Pascua, Tuesen, Yequis. "Oaly a ben observer alght note that the buses bere are different fru those closer to the center of the elty in that they are more constetently ourrounded

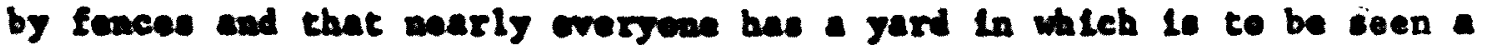
rough wodea crose a few peced from the house" (1940: 1).

Thls particular type of cross, anong Mayos, as aneng YaquLle, 3 bas deop maninge and wide Lntegration with other Maje symbole, and thus on importent position In Maje ethnic Identity. 
III. KURUSIM AM TEBATPO KURUSIM

Treec of Turue in

As wo aplored the kaje River Valley we found that the burue, a a phyoteal reality, bas indead a vide diatributloa. Hoat of the erveses seon wre mbere of the followlng types: above beth Mexleca

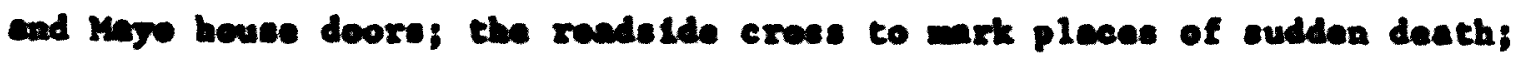

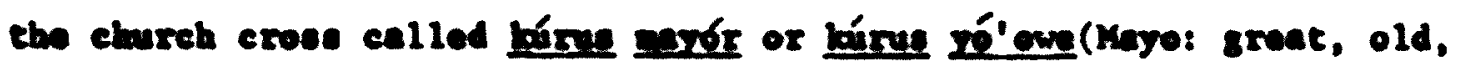

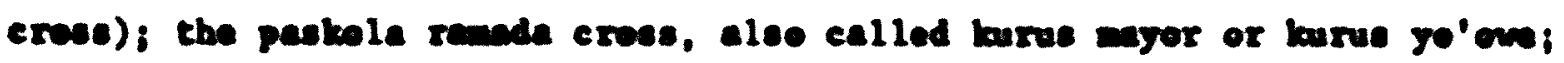
and the bouse eroes, celled tebetpo burus.

The Bell Pal Crese. An exaple of Lormal 1 Inkage between seme

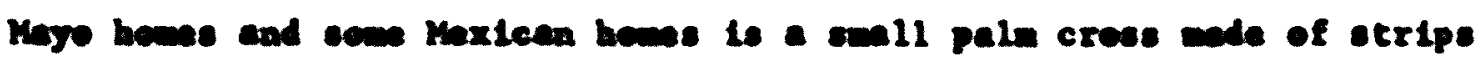
of pall leaf and pleced above the door of the boase. If the heuse bas

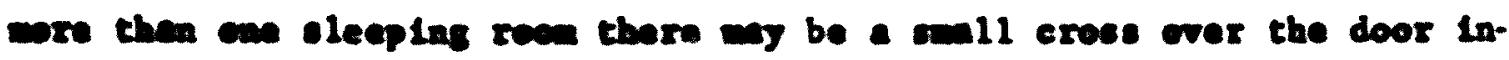
to each roca. Also this exwes whe obeerved thed to the roof supporting poets in som kaye bouses. The erose is about feux Inches tall and 10 tled tegetber with a etrip of paln leaf. Ne other Infornetion was obtalmed

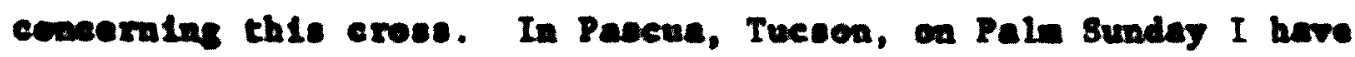
obearved Yapuls miking eroeses frem palm leaves. It is possible that the

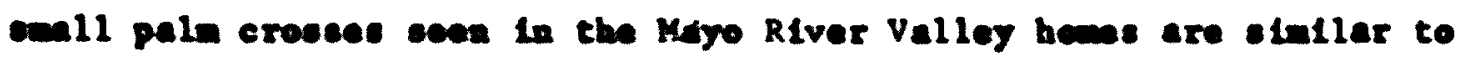
chese Tuceon, Yequl pole erosece In waning and function.

The Roedelde Crose to Mrtk Plece of Sulden Dach. Mas crosese are seen siply aloog the highway or in the toums aloag roads. These

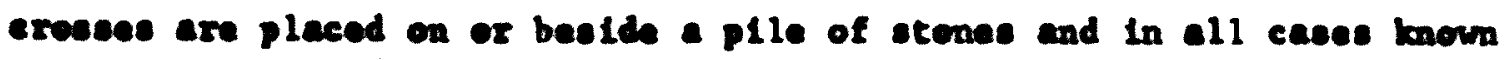


enth the locatien of a violent death. They 11 luetrate the sharing of form and som wanting between Mayos and Maxicens. Also som of the state highway departants of the United Stetes plece a wite cross at the slde of the highwey where person has been k111ed. The menting of thoce erosese, to drive cerefully, is probebly quite different, howrer, to kyos.

In a vecant lot in the city of Novojec there sterde a sall erves. One of our Hextcen frtends explated lt wa placed there becues a men wo shot and killed on that spot. Another croes along a canal we pleced there beceuse a gixl twolve yeare old hed fallen Into the cancl and drewned, expletend wother Maxicen friend. On the den at Hocuserf there 10 a erose of this type nariking the point where semone wes killed. Th1s type of erese also carries som of the sem waning for Mayoe. A few daye after a onall Mayo chlld wa killed on the highway - erese wa pleced to natk the opot. One afternoen a kayo friend of ours explateed to his wife in cur presence thet twe exwees placed together beslle the road on which we were troveling asibed the opot where two Yoremen bad killed each other with wachetes. Also the spot where

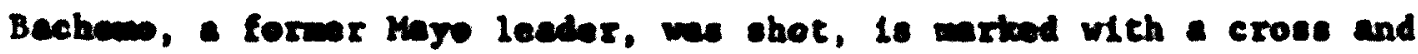
Have gelng thrwagh the elty of Kechls certy recke which they plece by the ereat (G111 1957: 128, phocosraph on 129).

Sinllar to the rweke on Bechemo's greve the other secred areas are often decorated utth flowers and ono often sees onll cans In front of the cresses. These cans were used to bold flowers which have dleapecers. In sem Inotances people have been observed decorating the erweses. These crosece provide a formal 1 intage, and som obered 
maning, betwen Mayo and Mexican culturea.

The Chureh Crose. Alnost every Catholic ehurch in the vallay has a large wooden cross, called the burus mayor or burus yo' owe by Yoremean, pleced about one buolred feet in front of the win church door, With the exceptiens of the eburabes in the follewing puoblos: Huatebape,

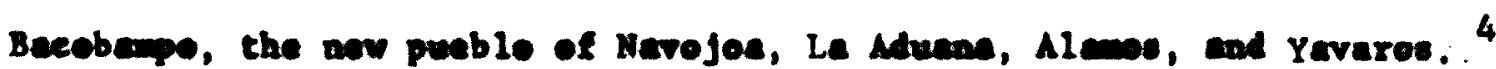

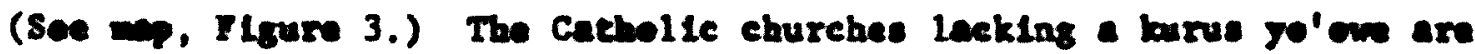

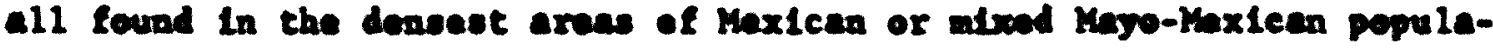
tion. Becoberpo it the eanter of a rapldly gronilas egricultural area and the church, we we told by both Hexicans and Masps, is a Maxicen rether than a Mas an. In Mbane wa settled in the coloalal peried

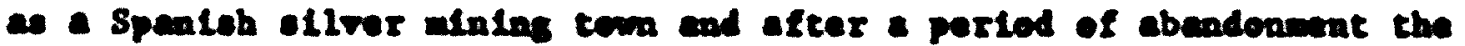

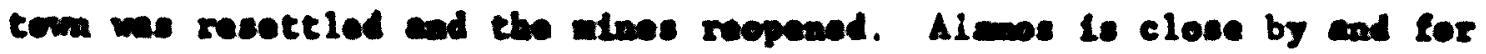

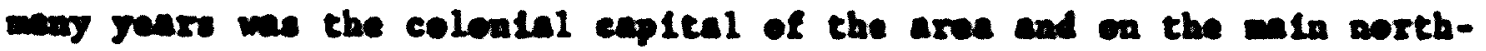

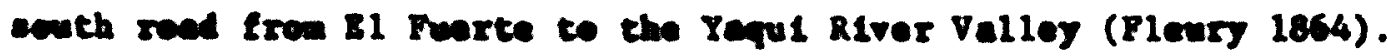

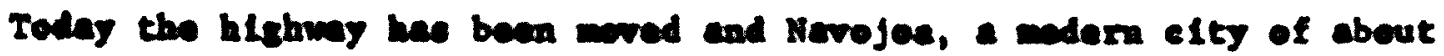

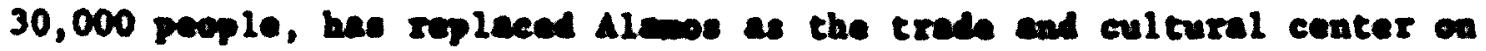

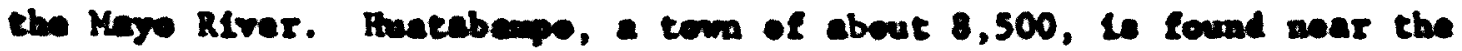

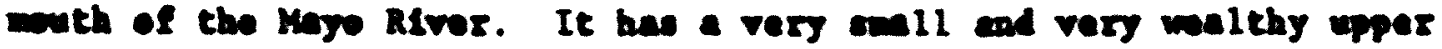

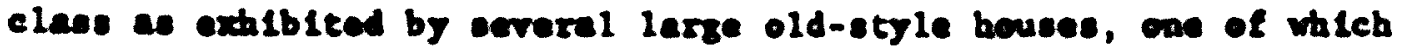
beleaged te Alvare Obrogen, 1910 revoluticang leader and past presldeat of Moxico. There are alse ecveral very wedera large bons. Then the veet rominder of housing in the tama is a cellection af very onall adobe or jacal etructures. The church, which is quite now, has a restdIng prlest, as does the church in the new tom ef Nevejes. These churcbes de not have a burus jo'ore of the Hrye type. Later in this 
anelyels It w11 be shown that the kurus yo'ene to a functional and nemingful part of wany if not all Mase church cerenonles. Thus the charches lecking then are wetcher Moyo nor are they foumd, for the wet part, in donse Moge populatiea arese.

The burus ge'ons is an cutetending festure of may more churches in the Mro River Valley than not; for exaple, those at Tepabul, Canoe,

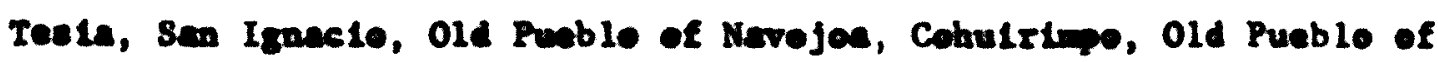
Sen Padro, Btchejea, Guajelecebe, Navowaxla, Jupar1, Etchoropo, and

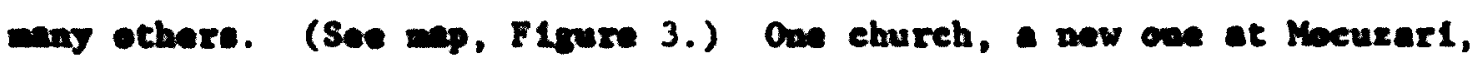

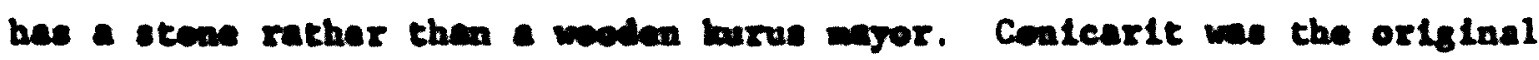

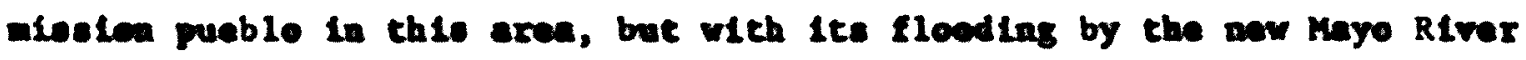
1.n the ealnte and rallgieus center were noved to Hocuzart.

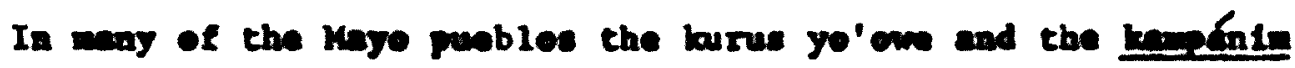
(Kayo: bells), Which usually stand directly behlnd tho crose, are

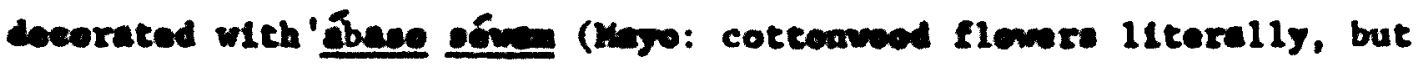

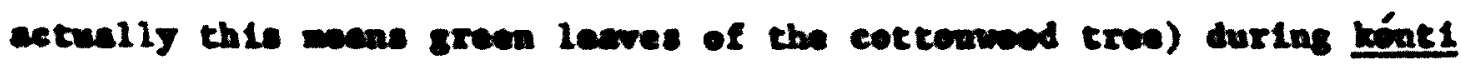
(Majet a regulax Sumby cerweny, In the ecase used bere). This is one

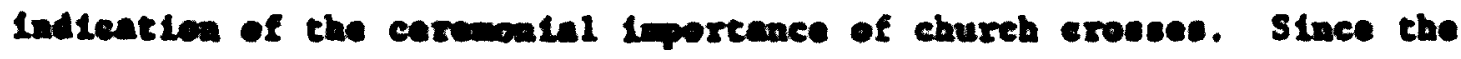
calnte Inside the church are also docorated with'abeso serwa soce 1 inkage between the burus jo'on and bell. complex and the eatete wate extet in Mayo thought. So the pattern of the eroes in Maye culture begins to reveel iteelf.

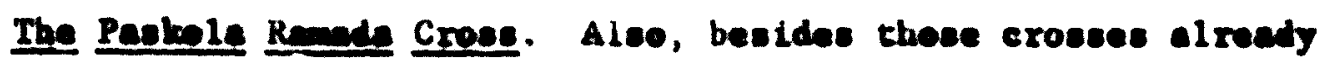

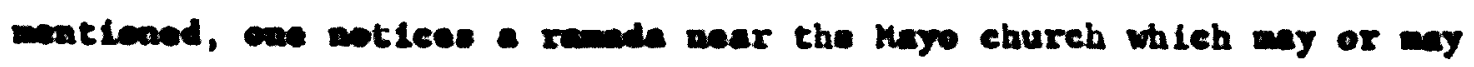

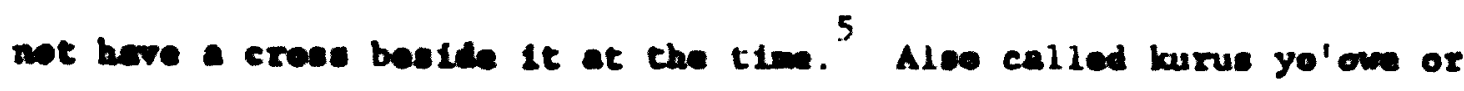

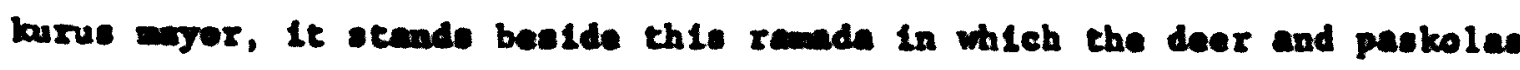


dence. Many remades have the crose only when a ceresoug is in progrese and st the end of the ceremony the pasko persenasim rewove $1 t$. During the cerrenony for a patron salnt the flag of the salnt is tled to the ranada crose when a service is not golng on which demand the presence of the pasko peroenas in in the church or In a processiea.

Pueblo Crose and Divlelon Llne Crose. The pueblos of Jupar1 and Etchojea here pueblo erosces where processions frem other puebloe ere officially wet and bid farewe11.6 The division line between the two areas of Navojos and Cohutrimpo is artad by a large wooden crose deted 1728. This date apparantly had been changed from 1778. Also, - eomplex of three crosece werke the diviston were the freah water of the Mayo RIver mete the ealt water of the Gulf of Californit. These erveses are only a for exaples of a clase of crosies, boundary crosses. Centery Crosee. The Capo Santo (Spantsh: cemtery) is also full of l 1ttle colored wooden greve crosece and has one large central kúrue del perd6n (Maye: erees of pardon). The omall individual erosaes my be replaced or repainted each November and the old ones burned. The croeces are palnted blue, gray, green, whtte, or black. Som are even orange, but cur friends secued to feel thls was a bed celor for a cemetery cross, the same as red.

Tebatpo Kurus. As one becoms better sequalnted with the river valley he begins to notice one or wore wooden crosese located In the petio In froat of sem of the houses. This erose or complex of croseses ls called by Mayos, háapo bárue (Mayo: crose at the house) or tebetpe burue (crose in the pat1o).

In the Mayo River Valley noet tebatpo burus in are of about 


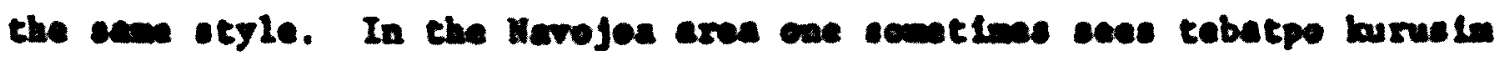

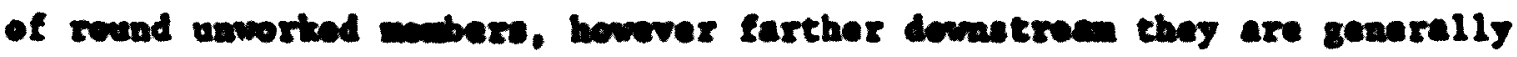

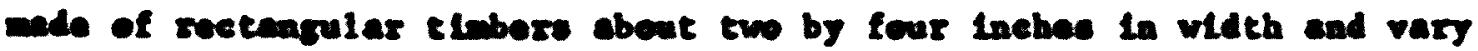

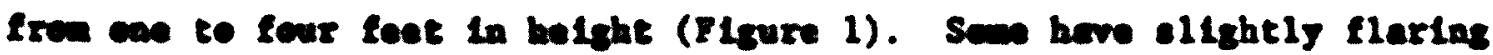

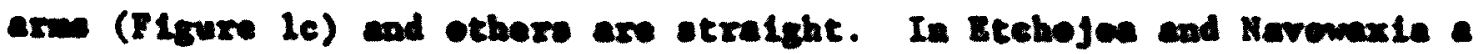
secend type of house erves (Figure 1e) whe obeerved. These interecting cresses, of elngle ploce contruction, wre obearved, in both locetleas. pleced bester a erees of the flrot type. 711 are upalnted.

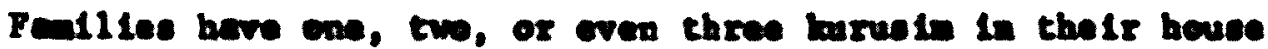
pat10s, the extre erosees depending upon the se of the first and second, eccording to sem of wr frlonde. For cae nover throws a tebatpo barus arey uten it gete old, but ofply pleces a new eno bebled 1t. Also a second or a third crous wy be set up to protect the old pecple of the heusehold fren falling, w wre told. 8

Apparontly com area opeclalieation exists is the form of tebatpo lurrule. For exuple, on the Lower Fuerte River, in the puble

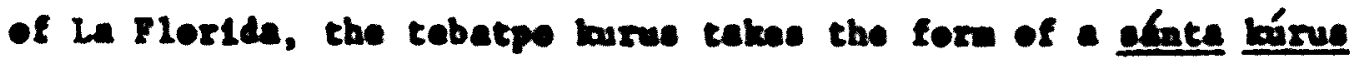
(Maye: holy ereas, ande of wod, with an areh frow are to arm). A bit farther up the river black tobatpe larus in are observed and Just south

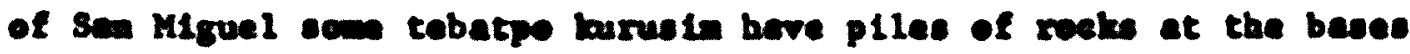

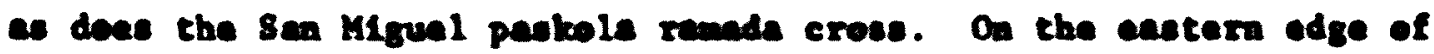
thle pueble sem erosece wth lethed arw ere towad. 8lnce, bowner, no Intenelve work we done in this erea, wo Mege explenation for these differences in form we ilecovered.

After som observation it wes noted that a burus has a froat and a beck elde or oae ste that lo alwaye the flewered alde and uoually 
FIGUR 1

Construction detaIls of Two TIPES

OF MAY hOUSE CROSS

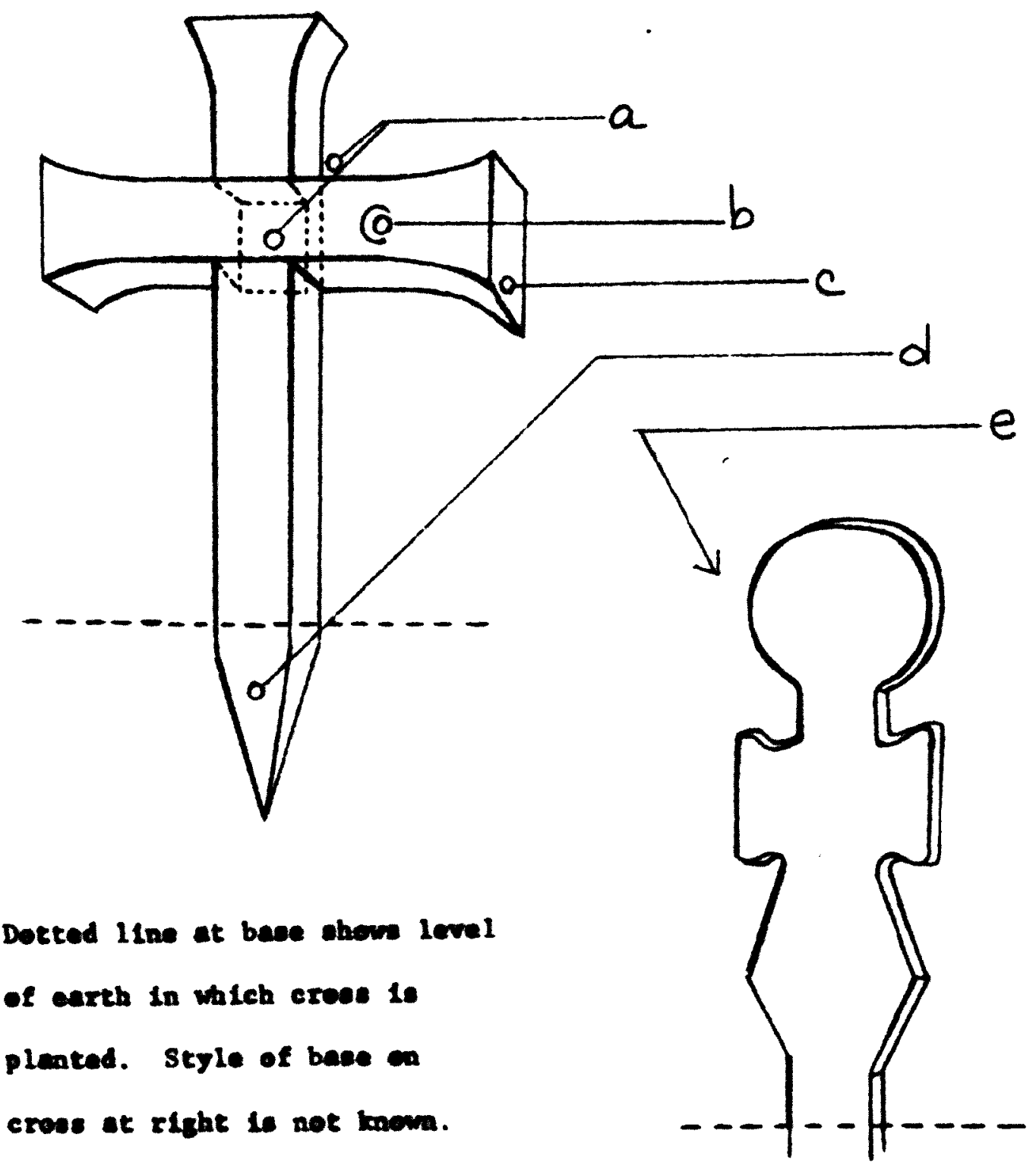


It Is this side that faces all setlon centered about or upon the eroes. $A$ soteh to cut from the inner fece of eweh maber for fitting the mabero together. The flurered side, or face, is the slde that presente the unbrolen crose nuber (Flgure 1b). The croes nuber is sometines fentened Inte the notch elther with a wooden pin or netel bolt, or ay even be tled In place. A metel nall is never used nor ere nalls used In furniture, partaps bectuse Chrlst was natled to the croes, as one of cur friends suggested. The polnted better of the eress is pleced in a sall hole in the ground (P1gare 1d).

Spatially the house cross is wost froquently located to the south or the enat of the house door and faces the door and the altar, which is co the wet will of the house (Flgure 2c,d). Among Yapula, Spicer has noted, "Every Yaqui bousehold has one such erose, usuelly to the east and sem thirty peces from the house; It any be from three or four to Ix or seven feet hlgh" (1958:435). All our Mye frlende had omall altare with pletures of several sentos on the west wall inside their bedrocen. Thlo posttioning places the back of the house cross facting the riving sun and the santos on the altar fecing the cross and the riolng oun.

It is Interesting to note that the tebatpo burus is found in the approulme directional relation to the bouse and house altar as the buras yo'ove is to the church and church altar. Also the sam relationship is found for the paskola rameda and the pooltiening of the perforning deer singers, who fece the rising sun, like the santos on the alter (Figure 2). Meny of the Maye churches face east, with the burus yo'on placed on the eastern elde, facing the church and its altar. The altax is In the wet and of the church oo that the santer face the 
BICURE 2

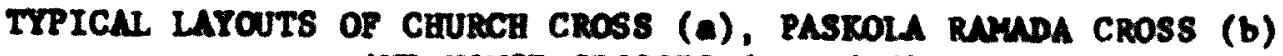
AND HOUSB CROSsEs (c and d)
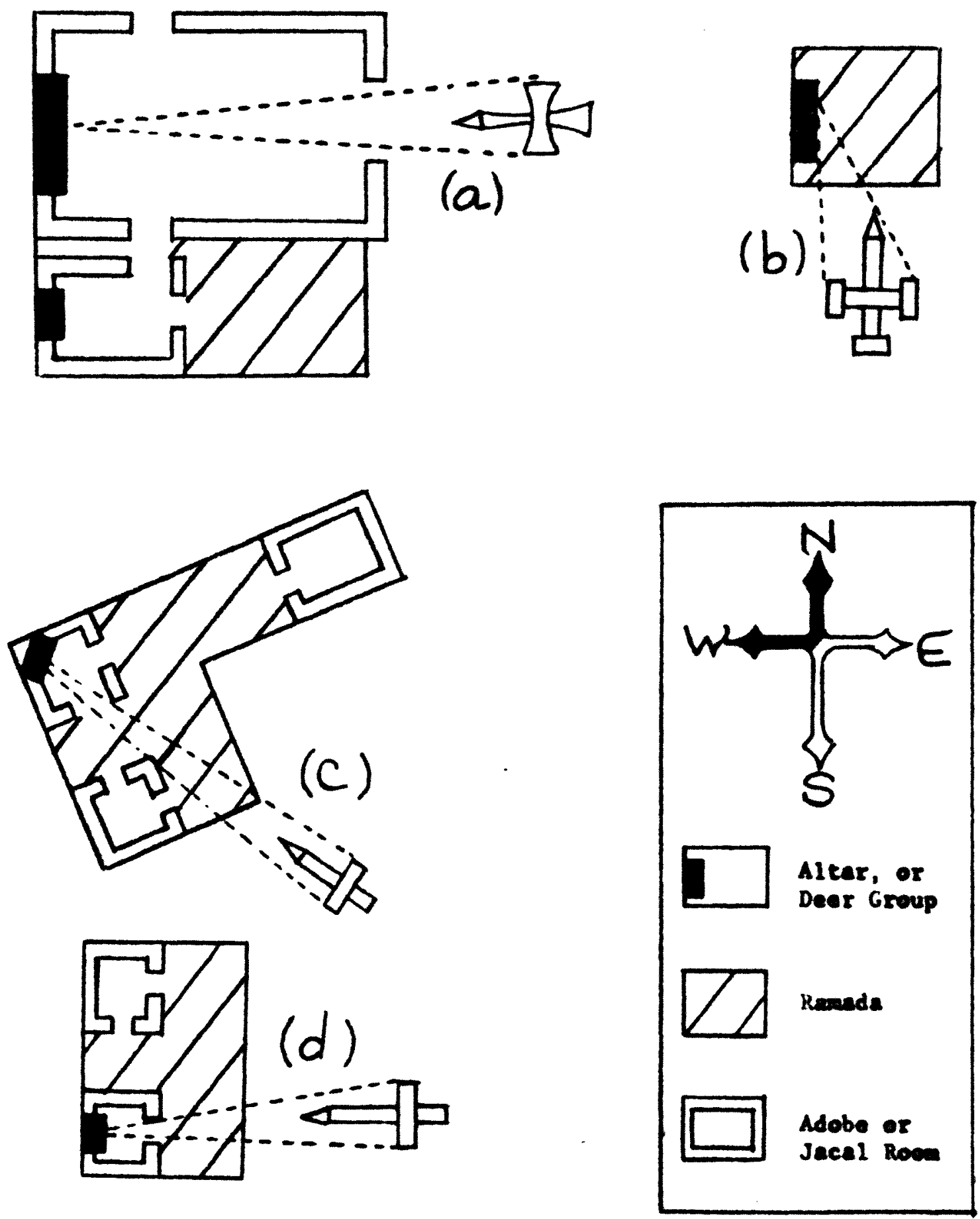
burus and the rieing oun, as do the santes of the house altars (F1gure 2e). Th1s is not the case for the Juparl church wh1ch was bul1t in 1937; however, the old church that it ropleced seos to here had the eastern orlentetion. Flgure 2 represente an Ideal type which 1. exemplified in the Navomante chureh and peokola rande directional setup. In all the pabkola randas we observed the deer alngers were seated In the wetern end of the remade so they sing to the directien

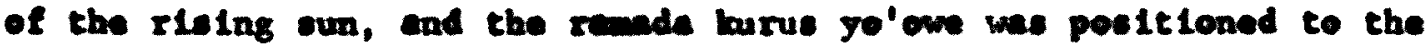
coutheast of whore they eat.

Thue we see that the hease erose, the chureh crose, and the packela randa erose obre form, and perbaps elemente of maning, in terns of directioanl relationohip to santos or deer elagers. Later we w11 shew that these types of buruste obare function and weaning.

\section{Hypothesis}

The preceding feete form the becksround for the presentetion of a bypothesls. My research was directed to gathering facts to 11lualnate or adify the hypothes le that the presence and use of a tebatpo burus together ferm a oyabol in the syston of Mayo ethnic Identity. As date wa gathered concerning the house crose and crosees In general, cereral lines of cantgele cane to aind:

1) A discuecion of arens where tebatpo burusin ateod all year, or ware eraeted caly et lont or fer a funeral, compared whth aren where fow or no house crosses were observed at an twe, to show how the distribution of tebatpo burus in alght correlate with other factora; 
2) A thorough examination of the material item of ecveral fanilies

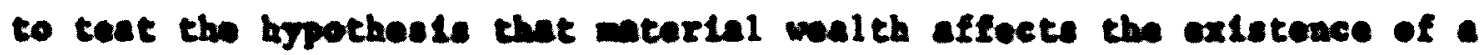

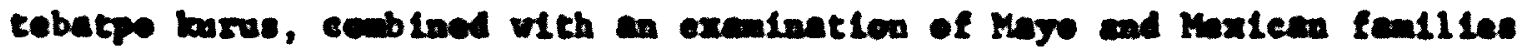

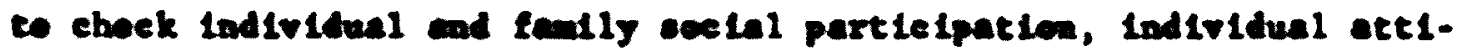

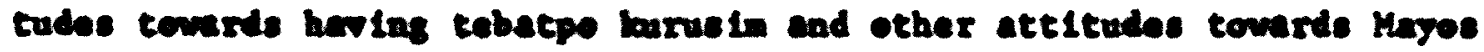
and aea-Hayes, all of whleh is to demonotrate that ea the fenily level

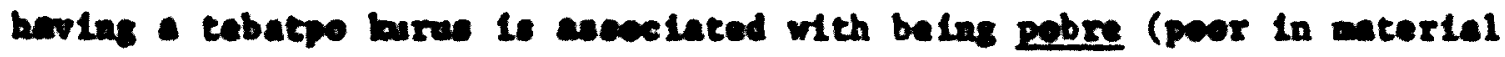

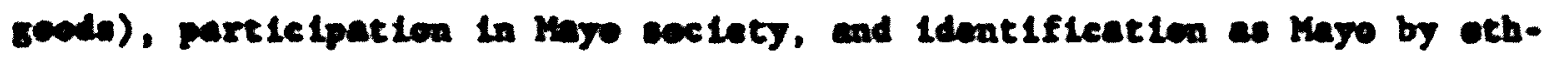
ex Mres:

3) A stwily of the I Intage of the tebatpo barus with Maye cerewonial centexte in order te dlecever the full waning for Hayos of this croes.

\section{Arens of Concentration of Tobato Kurusin}

In the early part of the fleld work a broed ourver loowledge of the river valley we exaght (Flgure 3). Many pobles wre rielted, and after trips the position of eseh erose seen, especially tabatpo burusin, we noted in the 108. Slace many puebles were pletted only cace or at wot several thes end nany croses are not pleced in plaln viow, there wust be nany wore hease crosees In exictence than were obeorved. With the exception of car visits in the Huatabmpo area, which were wre therough, these survey visits were conducted in a wore or lese uniform manner, elther alene or with one and the same informant. No attempt we ade to "flnd" croses; however, when one wes seen a mentel pote wes ande of its location, and lt was entered in the 108 that evening. Through the informality of this survey it was hoped that olatiar chances to see and note crosece would exlst for wost arees of 


\section{FIGURE 3}

\section{MAYO RIVER VALLEY PUEBLOS MENTIONED IN TEXT}

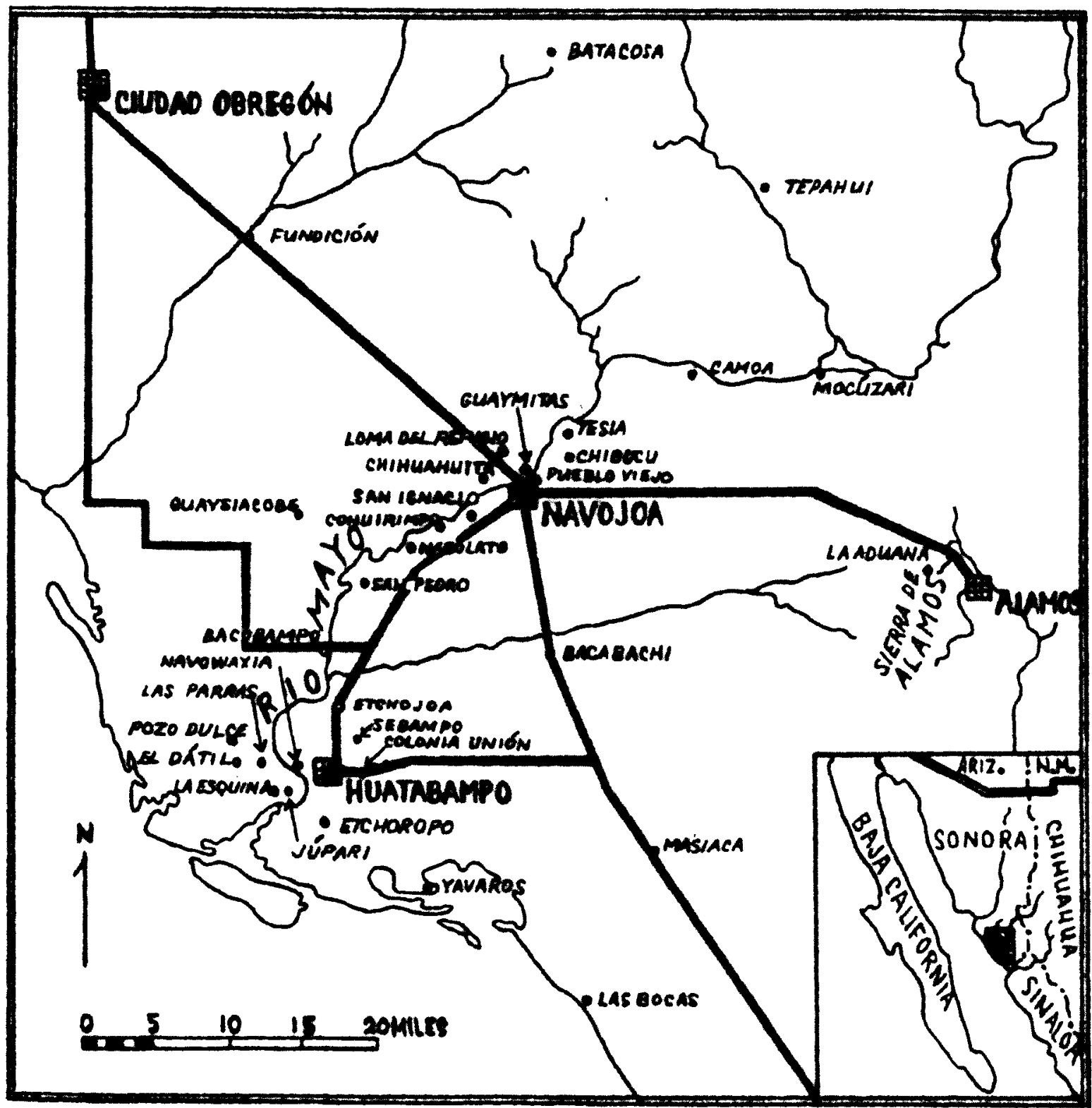


Three positionings of house crosses vere noted: flrst, a wooden burus from one to three feet In height on the overage, pleced In the grwand in the house tébet (Meyo: pat 10); secend, a weoden barrs from wa to three teet in helght pleced in the ground in the tabet only durlog the ceacen of Ient and chen ettber cempletely ronoved or ecaceslod In a buob latar; and chlrd, a moden kurus abeut three foet high coacealed in a bush or hung agelant a post in a ramad the jear

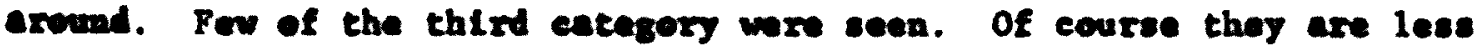
easy to cesually opot than the others. Owe woden crose, about threo fout loug lay hlgh in a tree in fruat of the bouse of wa of our triende. Apother we poted in a randa of a sequalntence. Helther of thase erveses were pleced in the ground during lont or ot ang tim

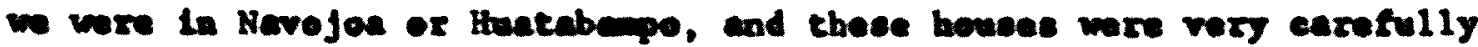

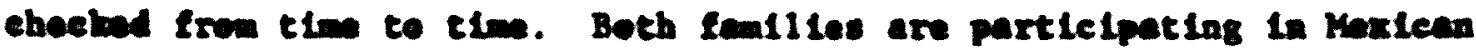

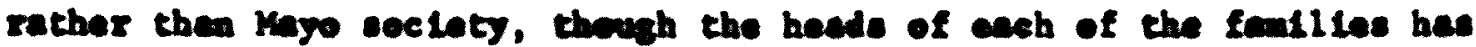
coe Mro parent, and in both eases thlo parent is otill 1 iring and vistead by this child.

The following churebes have kurse jo'owe and one or wore bells monted ca moden poles or a cement arch in the ground in front of or bealde the church: Topahu1, Canon, Teola, San Igaselo, Cohulringe, Sen Padro, Etchojea, Etcherspo and Jupar1. Thore ny be ethere of

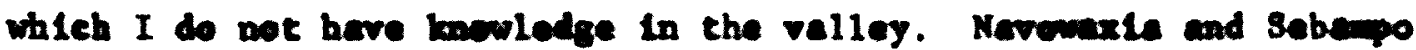
have burusin but ne bells, and the bells at Puoblo vieje, Navejoa, wro pleced In a tower on the roof of the church, ince, as one of

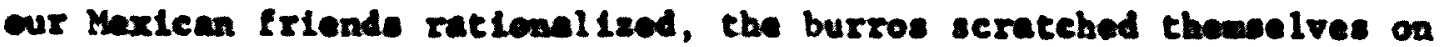
1t, ringlag the belle. The ronoval of the bells from thelr treditiean 
epot, along with the placlus of permanent benches or pewe Inside the Pubble Vlejo church, appear to Indicete etrong Kaxican Influence. Howner, the church et1ll retalno tte burue yo'ow.

House crosece extot on the northern elde of the river near Nevojea and in the bush barries of the muntclplo, such es Chibucu. A real cencentration of tabetpo burusto appeare as one nover farther down the river below Sen Ignec10. From this point to the wouth of the river one finds elusters of tebatpo kurusin in such pleces as Cohulrimpo, San Podre, Eteboropo, Sebarpo, and Jupar1.

Aleoe and Uertver Arees. From Teola op the river no crosese were obeerved even though saveral trlps were ande through thlo erea. It Is probable that they are to be found bers in Leoleted ectelemate. though they are not seen in the wore traveled arese. The lack of tobatpo burvein is this area, and near Alewos and Le Aduena, is porbopo due to certaln types of extended culture contect and Mayo cultural lons revulting from this eacect. Perlodic consuses obow that this area hes long been one of epare Mayo concentratiea roletive to the lower area of the river valley, and that the Spanioh ware wuch are numerous up the rtver (Acesta 1949: 100).

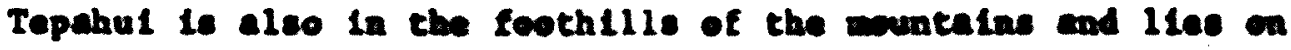
the old roed werth fru Aleme. An old echool in celoulel etyle architecture loceted in the center of the villege indicates a matively long and intense peried of ceatect. A church with a burue ge' on and bolle also exlote In Topahul, howerer no tebetpo burueln were ceen.

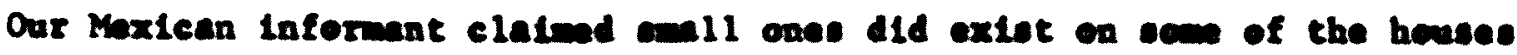
In the h111s. In explaintas that Mayo we not epolsen there in the 


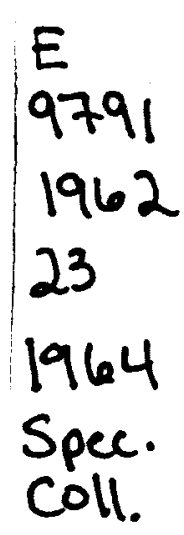


v1llege anjwore, he eald, "The poople are jorte now." In eupport -f this statenant he celd that the Lenten observances in Tepahul here

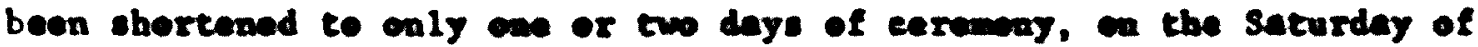
Glory and Easter Sundey. (In the lower valley cervanias centimue, off and on, for serven wekk.)

Moving on down the river to Canea tebetpo buruste are not obvicus. The early roed that 1 lnked Alames to the wre northern perte of Kaxico went threagh Ceman, naking poselble contimal Mayo-kexicen contact. In Comon there is a onll church with a burus go'om. Very inflar coaditloas appar to have existed In Teste. Though the early read itd not pase directly through this pueble the later rell roed did.

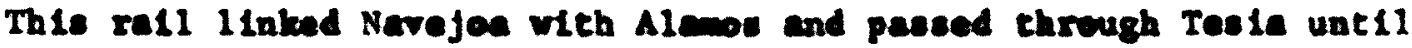
the 1930's wen lt wa rumoved. In Tesle there lo also a chureh with a burne yo'ow end bell. Thls appeare to be en erea of conslderable Mrye population and it is reported that leaten ceremonles take plece in both Tesle and Camoe. Both villages hed old schools which in the fall of 1961 wre belng ropleced whth aw ones. Standing tebatpo burusin were observed in thls area in guantitles at ChIbucu. Only a alle or two fro Tesle, in this puablo lives a paskola who is cas of the

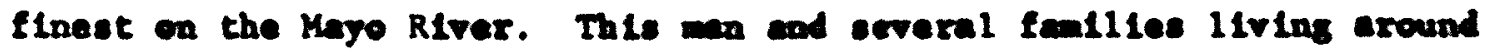
the area where hle hom La, beve stending tebatpo burusin. Also, in

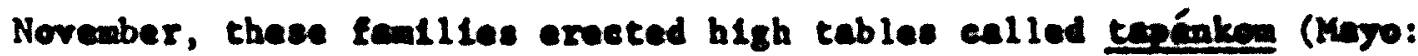
tables for the dead) where foed for the returning dead is pleced. The conservetivenese of this cominity is indiceted in the presence end use of their house erosses, se w111 be further explataed in follewing chapters. 
A tebatpo kurue was observed in a eanll rancherla near Tesia, leaning agalnet a seal-wall of a rulned house and faclag a house in use. Thlo settlement has a Mexicen ocheol and for thirty yeare has been under a program of intensive culture change directed by two aggreselve Mexican echool teachers. Even In this comentty, which hes been for so long under the Influence of such contact, one crose was observed and wore probably exist.

Naveloa Area. The relocated pueblo of Nevojoe, on the h11l, is a young town flret eettled arwund 1914 after a great flood wh1ch drove the people out of the older, lower pert of the eity. No tebatpo kurustn have been obeerved in the new eection of Navojos and only a few permanent cnes axiet in the old sectlon, near the old church with the kurus yo' owe. As stated earlier, the church euggeste Influence from Maxican contact.

Several tebatpo burusin do exist just north of the river nat the old eection of Nevojoa, however, In the barrios of Guagultes, Chlbuahuite and Lowa del Refuglo, for exaple. In Guageitas one very old house cross was noted on the south elde of a house. Th1s crose hed sunken Inte the ground so far that the crose nember wat wo wore than $1 x$ Inches above the ground. Also, en often decorated crose was observed east of the house of a piectre (Mayo: a yoram lay alnieter). Two houses wre noted in Chibushulte with permanent house crosses. At least one of the two fanllies are setive Myos, for they participated in Mayo ecelety as pasko pereonasin. We had no knowledge of the other fanily. In Law del Rafugle one house wa noted as having a decorated crose tied to a post in a randa wich is to the wewth of the house. When anked $1 f$ these people were Haxtean or kaye one of our Maxican 
friende tho lives in that area cuswered very poeltively that they are Yortmen. Alse another fanlly bas, hlgh in a tree baelde thalr bouse, a three and one balf feet crese. This erves did not conse down for lont, howerer. The head of the household eppeare to feel that he bes a eroes and It does not heve to be in the ground. Th1e, as whall demonstrete is bot the cose for a Yorom, for the tebatpe buras is an Integral part of partlelpatlea in the Easter

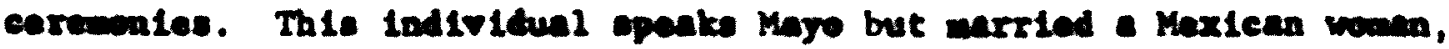
now prefere to opeak Spanish, partielpates as far as wo kow chlefly Is Maxicen eociety, and Identifles himelf an Maxicen.

Thus the erans elepest to the city of Novolea hove seme femilles who are Idenclfled by othere a Kay, partiefpete In Majo seclety, and have tebatpe laurueln; howrer the exea eppeare to have undergone Intenstre eultural contect of different types, and sone Hayo culturel 10as. For owple, ceneeruing the cervmony of the Holy Cross in Pubble Vleje, wa of the Maye lay atnieters of the aras nontloand chet

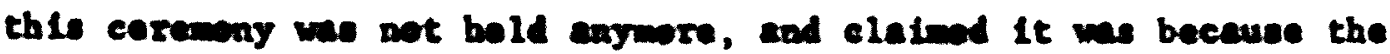
Majo pablo perconesin hed forgetten bbout it and did not care to give 1t anyore. 9

After the construction of the rell read and the rarle where Nerojen is todey the coma bogme to expand and becene the center for labor. Thus any people drifted to Navojon from ell of Maxico and It began to be a wre importint eserce of culture contect for the Maro Rivar Valley. In the leot fer yeare the rallroad owiteh has been moved north to Brpalm and mech of the labor that used to gether in Novejea now goes farthar north. 
Also on the maln 11 lo of the raflroed is the pueble of

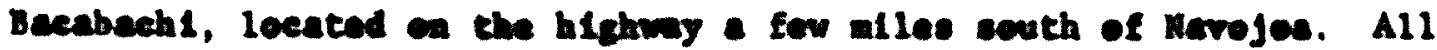
three typee of tebatpe burrusin are to be found hers: crosece in the sround all yoar; erowees in the sround ouly at Banter; and amller exweses pleced on fencee, in bushes, or troes, and which were never

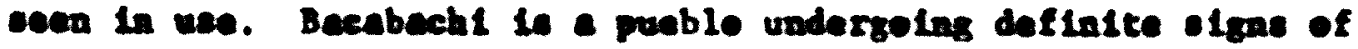
eultural chenge. Oee eld Beeabechl wann eald eadly that thirty yeare age ovoryose in Beeabechl was a Yorease and now they ware all gorts. But only during Lent we a tobatpo kurus pleced in the tabat of the boves wore obe bereelf 1 ived. Thus it appears that chrough cemporary or hidden exoseces one ean see eridenee of the fact that one eopect of Mayo identity, at least, is beconing lese inportent to sem of the people of Becabechi. Oaly a fow miles into the bush west of the highwery noer

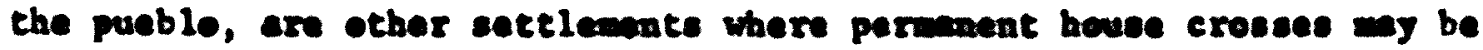
found. During Lant, Mayo friende reported, my fanlliee in these oettlements had heuse eresses down for the seseon.

Cebulripe, Sen Pedre, Bteholee Areen. Farther domriver the coremonfal centers et11l eppear to be Intect. Cohulrimpo has a sall Maye church with ceveral bouses with tebatpe burusein clesely ourround ing 1t. Near Cohulrimpo, In Nabolato, 1s located a feally with tabatpo kurusim. The heed of the bosesbold refused to apoak ang language but Mayo when we visited, weo participating in Maye eoclety as a cerenonlal performer at leat and at a peako peruona.

Both old and New sea Padro are dense areas of tobatpo kuruela with nearly a wany if not more then the Juparl ares. In the old Preblo of San Podro a boces crose was noted at the house of a fenily 
Which opole only Mayo on our vielt and which wa particlpeting as a household In Mayo ceremoniel life. A Mayo church is aleo found In Old San Pedro, with burus and belle. Many tebatpo burusin were aleo -beerved In New San Pedro, one fandly beving two onall crosess with the onallex, or older, placed juet in front of the other.

In the Becoberpo area only one tebetpo burue we observed, that of a fonily living several alles north of town, in the country. This wa at the home of a fantly of Yequi fireworke mkers. During our vielt to plck up som fireworke for a ceromony, ealy Mayo or Yaqul we spoken. The older man of the household expreseed a deefre to go to the big Yaqui pueblo ceremenies and appeared somenthet hemesick for the Yaqui country. HLe obvious Interest wa Yequi rather than Haxican In this respect, and his tebetpo kurus reflected his interests.

Bacobemp, a noted before, has no Mase church and, we were told, consiste largely of Mexteane rather than Mayos. Farther north is found the pueblo of Guajelacobe, with a Mayo church and eluetere of houses wth tebatpo kuruein, surrounding the church.

In Etchojea, during the cerewony for the patron salnt, Eaplritu Sentu, several crosees were plseed in the tam. Just outside of Etchojee three pueble croeses, showlag the boundery, were erected in a fleld. Here the Btchojea pako persenasta met the dounriver pasko percoaveln who wre bringing the inges of the Santisime Tinirens from Juparl and Etchoropo churehes. The procession woved on into the tom, resting the ealnts at a point where two crosses, one of esch type show In Flgure 1, had been placed, and then woved on to a houce with a lexge tebatpe kurue. The house crose we at the end of six palm 
arches through wich the procession passed. The Sanclolua Tinirans then rested at the house before contimuing to the church. Several daye later it was noted that the erosaes, except for the three marking the puablo boundary, had heen removed and were leaning against the wall of a house nearby, not even the same house where thoy were used. Also In Rtchojos was noted a cross concealed in a ramada. This cross did not cowe down during Lent. This case is similar to that described for the Mexican wth a Mayo hletory in lom del Refuglo. The hoed of this Etchojoa family knows the Mayo language, has one Mage parent, but prefors Spanloh and participates In Mexican soclety, 1s educating hls chlldren to be Mexicans and Identifles himelf as Maxteen.

With Lte Maro church, Sebexpo and lte eurrounding puoblitos fers a ceremontal oubeenter, heving groupe of house crosess, especially close to the church itself.

The ceremonial centers, euch as those of Cohulrimpo, San Pedro, and Etchejon, which calebrate the seven weoks of lont and the local satate' days, are areas of stroab Maye ceremonlal participation. They are also anoug the arvas of highest concentration of tebatpo kurustm.

Huacabampe Area: In the vicinity of Huatabampo, Ineludiag the puebles of Colonie Unien, Etchoropo, Navemaxla, Jupar1, Les Parres, and Pese Dulce, by fax the largeet number of tebstpo kuruein were seen, bowever the longest and wot Intensive perlods of fleldwerk were opent In thle area. It is probable that Huatabapo hes been a Mexicen culture center, reletively epeaklng, tor many yeare. One eld Mayo cowboy eald he could remember wen it we efmply a few Maro houses. At the the of 
the 1910 rovelution Huatabemo had a garrisen of forty an well armed and supplied under the erders of the munteipal president (Obregen 1960: 5). For the lact several years fleatabaspo bas had rall and highway connactlons with Novojea.

In Huataberpe one fiods that neny foullies only place their croseas in their patios during lont or for funerals. At other tednes the crose is concealed in a bush or pleced at the alde of the howee, or semavere out of elght. One men tho has lived In Huataberpo nearly all hl. 11fe, havlng been born there, particlpates erery year as a

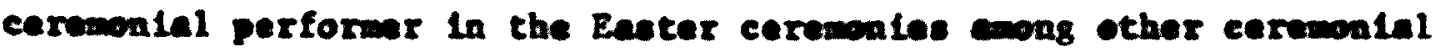

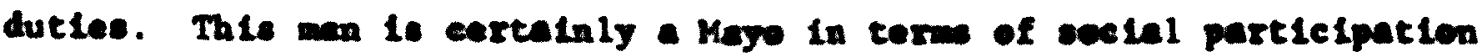
and definitely bas a house crese, but we know him a loag tim before motted bis house crose. It is ted in a bush.

Yavares 10 a present day port cown and to a elnod Maxtean-Megs cecoumlty. At leset two bouses with tebatpo burusta exist en the edge of toun. A rallroed from theatabengo used to tur to Yavaros for alt and flob though it we nowed a few years ago, and nothlng but the rellreed

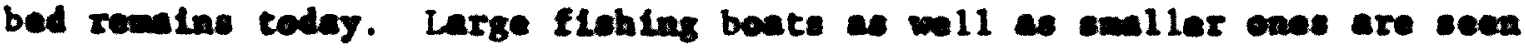
In the harber and any North Americens as wil as rich Haxicans use it a a flohing port. Thus Yevaroe is a couplex port town ratber than a censervetive Mogo etroagbold.

Colosic Union to a comparatively rich farming ojldo couposed of may Maxicen fealliee as wil as Mayos and constets of adobe heuses recher than jecel for the wet part. Alse during the period of rescarch electricity we Installed in Colonia. Some feallies beve tobetpo burusin there. It is interesting te note that of the three fonllies 


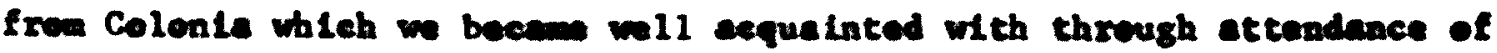

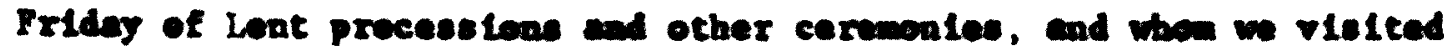

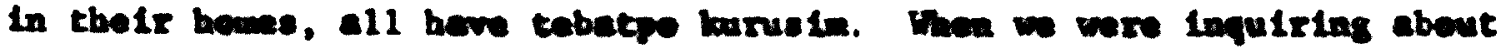
the locatione of a Mayo fanly in this pueble, the etranger whe was

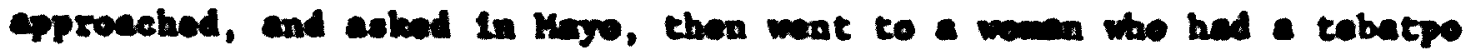

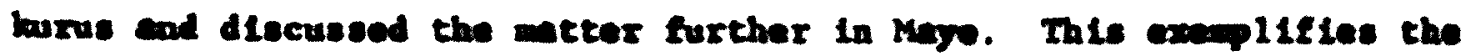
pattarn that fonllien with tobatpo burusin wre generally found to use

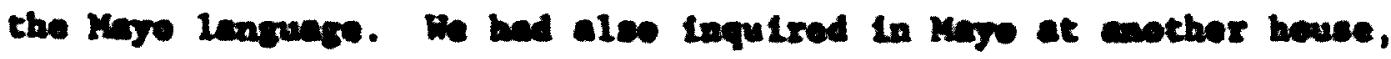
without a tebatpo burws, and the canor cam beck in spenioh, "Whet ere you sel1 las?"

The peoblos and currouding arese of Etchosepe, Novowate, Jupart,

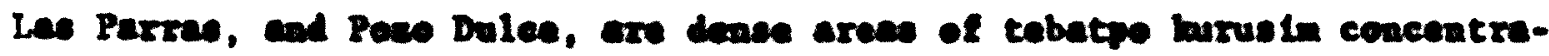

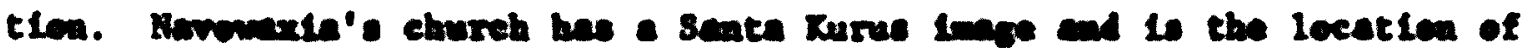

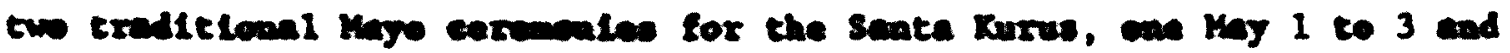

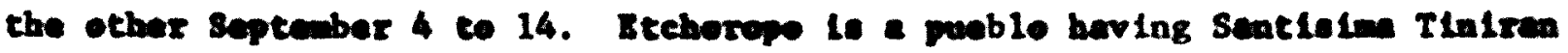

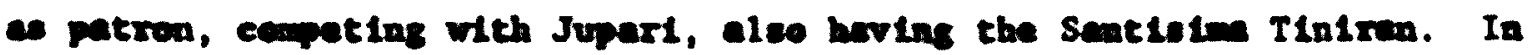

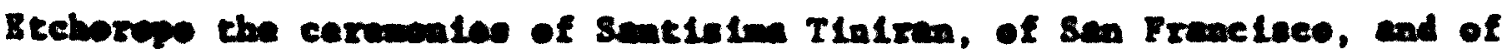

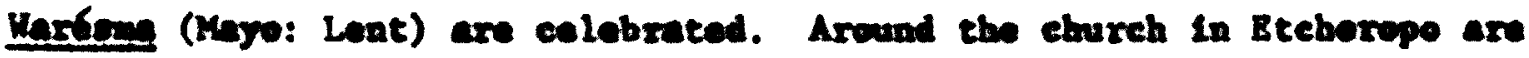

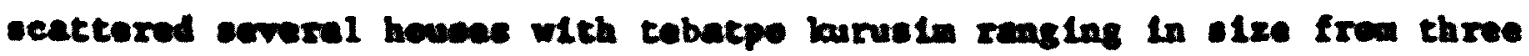

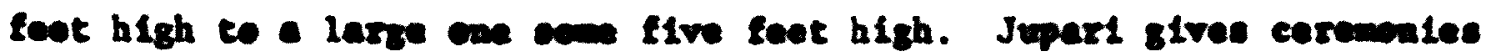

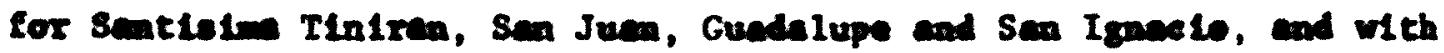

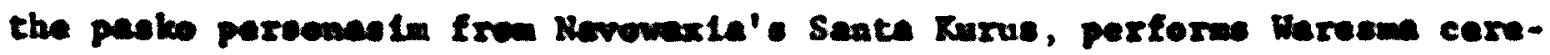
wonied. In Juparl Iteelf these are, out of about elghty-five houees, enc forty-five with tobecpe harus in and of this muber at leset two

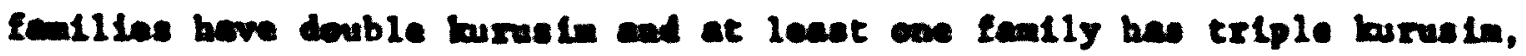
with is the bigheet cencentration of bouse erosece obeerved in a vilage 
elther in the Mayo RIver Valley or In the Fuerte RIver Valley. Near Juparl were the old brldge wa, there ere several houses with tebetpe kuruelm. These houses are located on the hlgh worth bank of the rifer near the ascred Mayo aree walch is marked with a large crost under a huge tree. 10 Just ecroes and down the river is the bom of a men who If beth a Majo and a Kaxlecin In som reopecte. He had a houpe crose only for lont and often attonde a cermony only for a fow almutes; howver, he prefera to openk Spanish. Oae Mays fandly called him a Yorem, although thay beoltated conalderably about cleselfytas hin

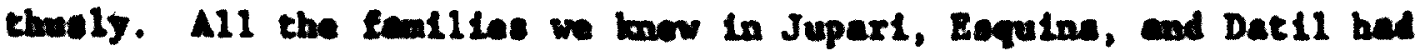
tabatpe burrosin and particlpated in Maje ecclety, though there are also ben-Kage resident in all thase settlements.

In this chepter evidenes has been presented to danoustrete that all up and down the rtver a high density of tabatpo burueln eorrelates wh Maye social partielpation and with the dietribution of cercuonial centers. In the following chepter the Eandiles that w

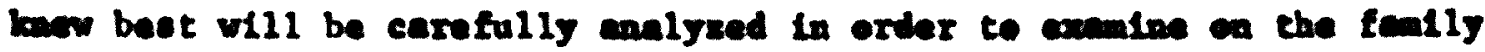
Iovel the hypothesis thet Kose othnie ldentity and having a tobatpo barue are poltively correleted in terme of soclal participation and cultural behevior and thet wealth does not correlete wth the presence of e tebatpe burus. 
IV. SOCIETAL AND MEALTH CORRELATES

OF THE TEBATPO KURUS

Material Wealth and Instances of Tobatpe Ruruelm

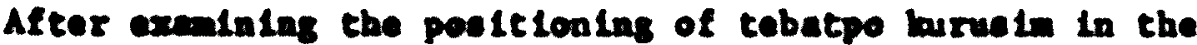
Mro Valley and realizlag that only certaln bowees have a crose of thle type owe beglas to exemine other appecte of llfe whleb way be chown to be in a relationahip with the existence of the house cross. A prelininary hypothese wa formed that westeh, as easurad by the bouse and enterisl item owned by a fenlly, wa related to having a tebatpo larrus.

A list of seterial lten we wade cut and twenty-three houscholde wre observed durtag viste. At no tw ware individuale asked about ownerablp of lten unobeerved but the Iten wa ofply left blenk untll lt we elther obeerved or lte absence was definitely noted or unt 11 the informant velunteered Informetion on the subject. A wre direct surver techalqu was not aployed for coveral reaseas. Firot, thle sort of technique, w feared, alght leave us epen to euepleton. Peeple tend to question the reasons behlnd such an approech and wo did not wioh to be linked with Haxtcan enchants, goverment efflelale, or any other ouch group. Alce it beceme apparent that poople often exaggerete tholr walth when operating in Mexicen ooclety and aloimise it emos Kaye friends. Mayos often say, "We are all equally poor," when directly abled about thelr walth, which has a great deal of truth in 1t. Since the number of fentlies we could efford to etudy intensively 
was to be comparatively andi it wa neceseary that aleinfermation be ovolded to the greatent axtent poselble. After arvervi chate in

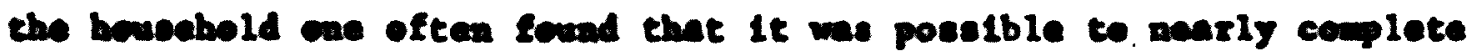
the sehedule witheut boving abled any direct qeations. The blenice ruminiag eculd then be fllled in later vistte. It we our experience

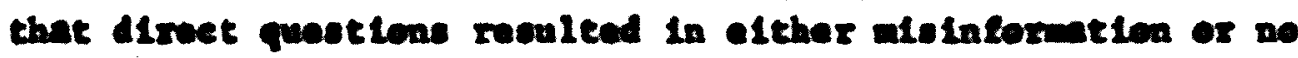
Informetea. Thus the saple eseriflea largenase of olse for thoroughnees and rappert.

The anjerity of the houcholde are taken frem the nnielele

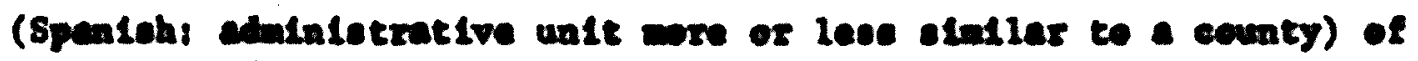

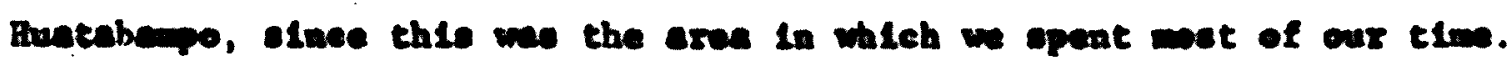

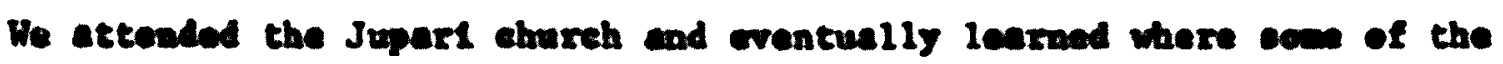
peple whe wre recoptive to us lived. These peeple, plus ecreral

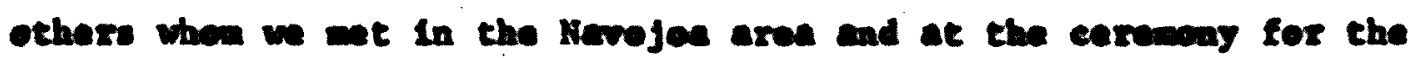

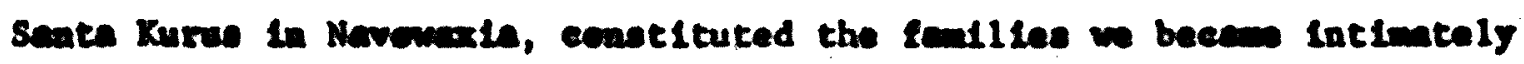
cepaluted with through vistts and coumon cervonial participation.

The schedule Included a list of the following 1tams: elobe bouce or Jacel; three adobe roems or fewer; electric lights or none; bught corn weal or metate-ground; red1o or nowe; shoes or eandals; more bedo or more cete; palnted furnlture or not palnted; Mayo blankat: or other; well or tep unter clese to house, or canal vater; own land the house is

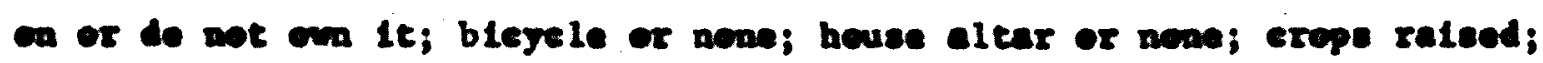
cowe or noes; seste or neas; bheop or nene; plge or none; horees or nowe; sewing wechine or. none; number of working acults in bouschold; muber of dependente; proximity to a church-eaneters area or proxinity to amiclpel center; and the tebatpo barus wa obearved and noted as 
elcher absent, In the ground, In a tree or randa or fence, leaning to the oide of the house or in a bush, and/or standing only during Lenten sechen. Alse we noted $1 f$ and won the house erose was decorated, and with wat type and color of flowers or decoration. When the households wre tabulated and coupared it was discovered that no differances could be found between some Mexican and some Mayo houseblds with the exeoptions of the exietence or nea-existence of a tebetpo burus and 1ts assoclated patterms. Dr. Charles Bresmis also concludes, In speakins of the toumseople's luplag of country Maxicans and Meyos, that a real confusion does exist, for the houses and standard of 1 iving are often quite Indiet logulohable (1961: 203). He also stetes, "Yost houeing in the country villages es wl as whe of the thlrd-cless housing in town 18 inple cornerpost coneructien with adobe or mid-and-wettle wils and dirt fleor and earth root, and coste lase then two thousend pesos or under andred and elrty dollers" (1961: 206-207).

Our eaple conelsts almost entirely of mebere of this group; for exaple, a typteal Mexican housebold in our semple has a enall one-room jecel house with no electricity, dirt floor, water supply frem an open Irrigation cenal. A comparable Mayo bousebold owne jecel house, has no electrielty, a cenal weter supply, uses wetate-ground corn mal, and own no animals except chickens. The poverty of both houses is almost Identlcal, but the Mayo house lo maked by a tebetpe lurus wich 1 of often decorated and cered for. Both household beads do partice labor and work owall efldo parcels. The oum 1961 the Maye household produced four bectares, or lese then cen ecres, of cotten, the masy earned solne to pay debte, buy now elethes, and to 
gtre and attond religleus ceremontes.

These cases ere typieal of many Maye and Mexlean fanilles, and domenotrate that vistble walth and earning beees of kayo fantlies

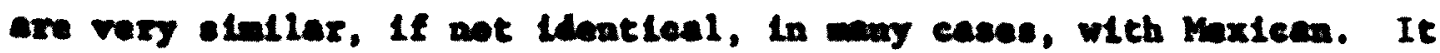

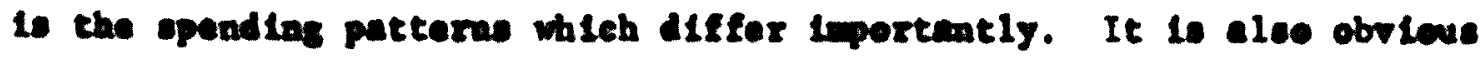
In the ennple that one of the fow inportant differvaces whlch is phyeleally ebeervable between this type of Mose and kaxlean fandis is the extetence of a house croes and the patterns soseclated with it. Attendenee at and particlpatien, eften through oponding, in Kayo

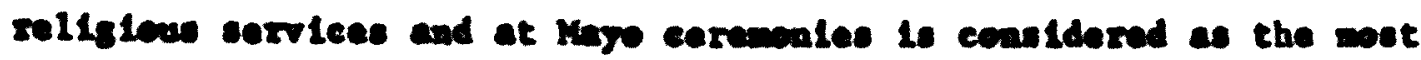
dLegoetle eype of kayo soeinl partictpation.

Ocher kns beapeholds have wore aterbl objecte, for oxmple

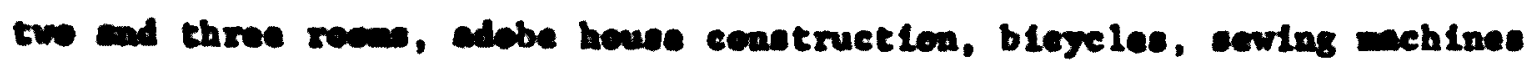

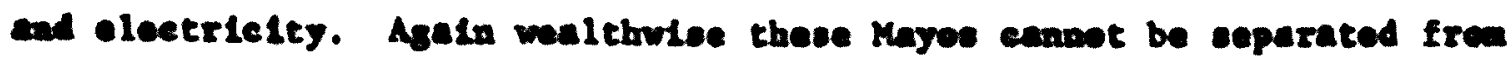

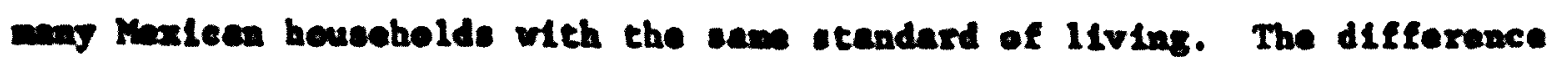
agatn lies in the vialbie rolistous oymbis and in the having of a pattern of sesial partielpation cennected with thowe eybols. Wealthler

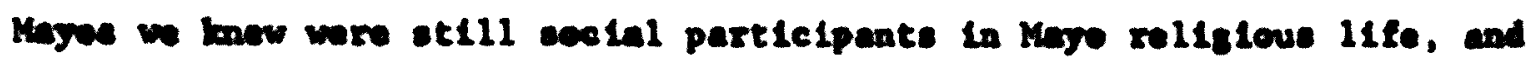
often che etrungest case. Thwe a combinad ceaslderatica of walth, scelal particlpation, and fandly standerd attltudes toward ealf-leontity

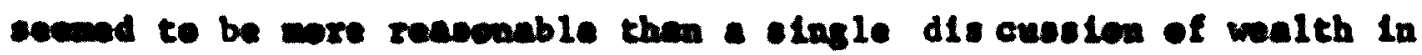
Kaxicen and Maye houscholde. This is aply domonstrated by the follewIn Eace.

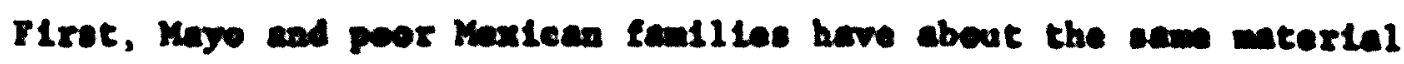

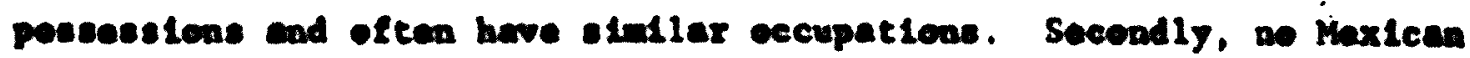
fandles appared often enough at Mayo religious ectivities, cur min 


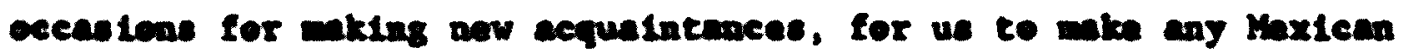

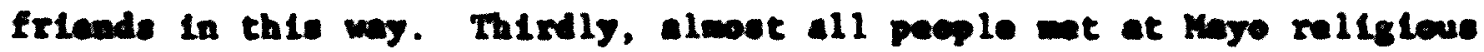
ectivities eften energh to beceme our friends turned cut to be able to

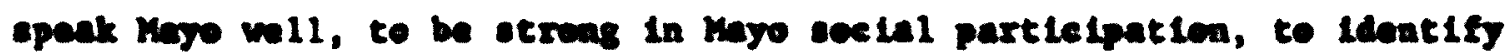

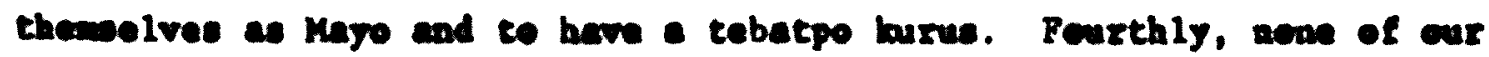

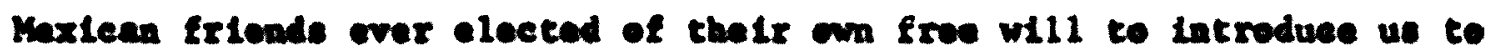

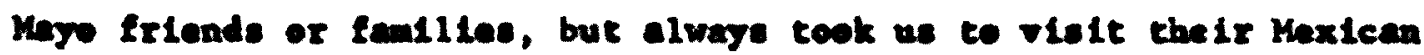
frtende; whereen Heyos appeared to vislt thelr om Maye ceremonlal end

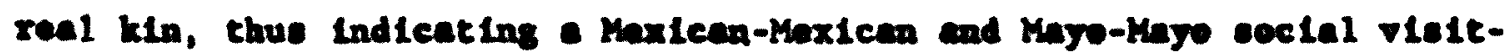
ing pattern.

\section{SIgniflcence of Location of Houses}

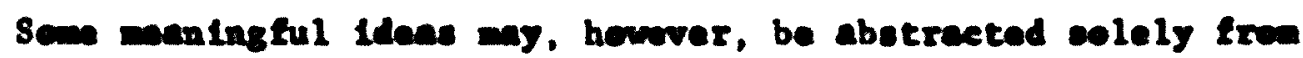
the aterial collected oa the walth and loestlen of the houschelde; f1rot, Moxicen and Maye eatelement patteras vary in sem lecales, and

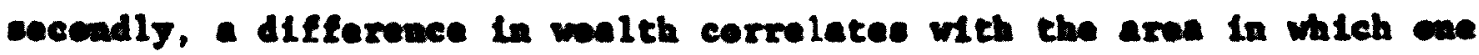
Iivee rether than with Haxlean or Maye ethnic afflilation, for the wet part.

Difference in eottlemant pattern for Hespe and Haxleons appenred particularly in smil v11lages, such as Etchorep and Juparl, and in

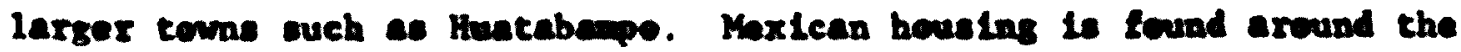
butnese and school arens eet op in equere blecter with the houses fecing the streots. Majo ecteloment pattern at firet appears haphasard. Howner, efter careful exnination, several geanral rules way be abetrected: flrst, the plecing of houses east, eouth or southeast is very common in the villages; secondly, the posttiening of Maye houling in the 
tom 10 ofinlerly pattermed. As has been noted before, this pute the hoves eltar in a cartain iefiatte relationshlp to the bouse erose. 11

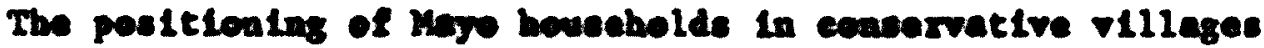
Le geverned by the generenl rule that the bewee eluster around the Hype eburch and cenatery, or arwand the edges of lexger tomas where there to so Mare church. Por axple, woet all the boused vith wbatpo burusto In Jupar1 and Etehorope are found elestersd arsund the Mayo ehureh-eenstary secred area, ad the Kayo houses in Harabeapo ofth cobatpo burasin during Lat are found alther noar the cantery or

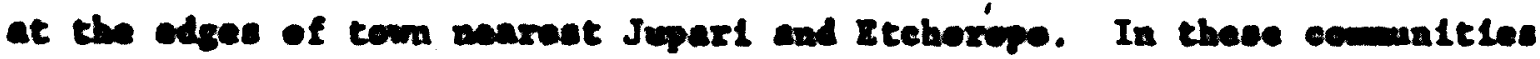

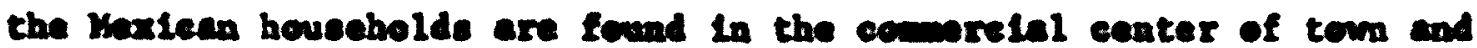
axwand the schoels. 12

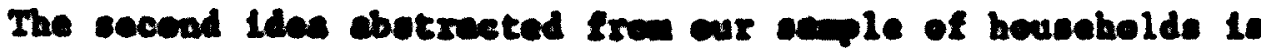

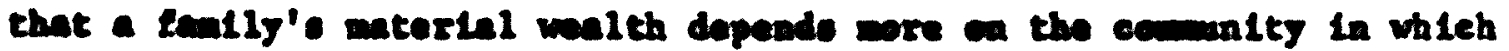

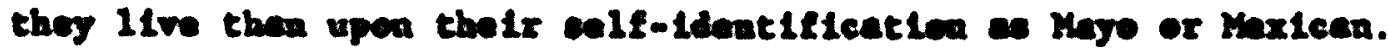
Heatenberpe, Colcale Onlea, and Jupart together show not caly the renge

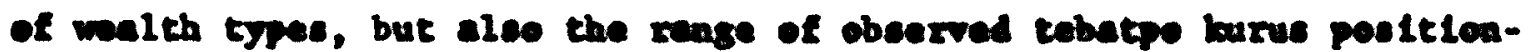

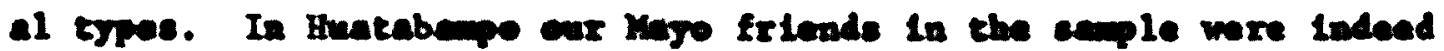
poer, boving ealy jecel hovee, with no electriclty, no redie, water carrled from a public aplget or from eanals, a bad, and one or two bendade chatrs. 13 The tabetpe burue was elther diogulsed in a bush or cemletely hidden frem view eneept during lont, when it becena guite obvicas. This is parbepe a recult of feer or soclal presoure in Huatubepo, since definite seoctlons bove been brought to bear egalnot the peste (Mage: a word referring to the pabkole and deer dance and

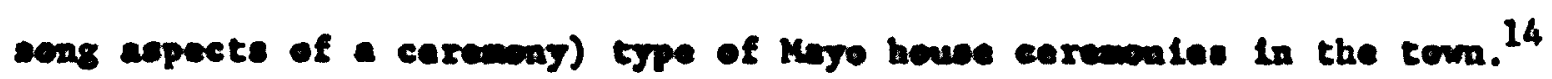




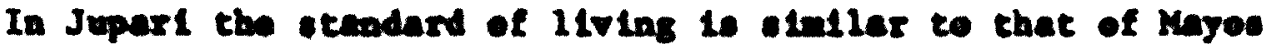
In Heatabepo. Out of som forty-five bouses which bove tebetpo burusta all but feur or five are jeal houses without electrielty, and with a weer supply fren a canal or ahallow mil. of the ceveral of these mileh ars adobe, one hen a elagle adobe rew vith no electrictty and w chalrs, ouly benches, and cae of the otbers is cerees com from the church in the Kanlcea sectlon, and hes two edobe rown, a jacel

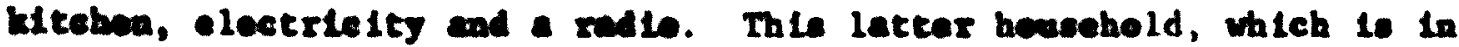

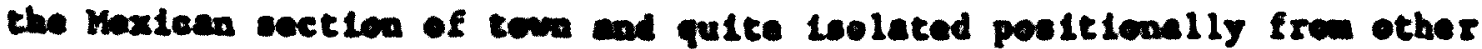
Xaye houces, hes for mang yeare lecked old pecple and is not one of the censervetive householdes howrver, the sectal partielpation of this

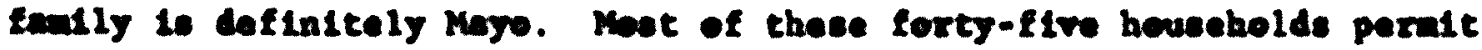

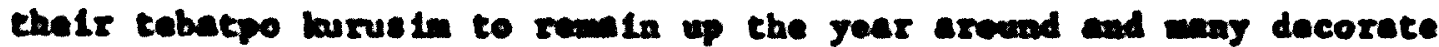
then for the day of the sente Kurus, Kay 3. In Coleats the risyes and Maxlesas are both rleh, reletive to the stenderde of Jupart Hyos and Maxicans. Celeala bas very few jeenl bouses, the mjerity belns two or chree reom in adobe constructiea. During our fleld recearch period electrictty we installed In the comanity and oven before this the emple of bousoholde there included posseseore of bettery rad los. In edditlea wil water is eold throughout the cemanity or people carry drlaking weter frem wils and not from irrigatlon cavals. Por an exaple of a bouse in this pueble, a representaclve cae includes two separate edobe room and an adobe klechen connected by opeclous ranades, - redis, chree bede, lour chatro (two of which are rocking chatre), an umpedded diven, two bleyeles, ead a eewing achine, and the fantly we leoting formard to electrletty and hoplng for plped weer in thelr pueble. 
They had, however, throe bard-working wen. On the whole there was no my to distiaguleh, by etandard of living, Maye households such as this one from Maxiean households of Colonia Unien, with the exception of the presence of the tebatpo burus.

In concluelon, then, ethnie dietinctions betwen poor Maxieans and Mayps eanwot be based on stendard of living, and though settlement patterns are belpful in some comunities they are not teolproof. Also Mayos frem different villageo or town, although thalt coclal partlelpatlon as Mages le talxly equal, have different scandarde of liviag, though thas do not gemerally adnit 2t. Thue walth apperently does not show whether the household is Mayo or poor kaxices, but depands, at least partially, upon the cemounity of which the bousehold is a part. Peorer Mayo and Yaxicen people tend to live in Jupart, for exesple, and richer in Colonis Union.

\section{Socletel Correlates of the Tobatpo Kurus}

Fourtenen of the Moxican and Maye fanliles whon we know beet and when wo visited or who visited us most oftem ware seleeted and dividad Into three grompa: Maxilean, Maxican with Mayo enceotry, and Kayso. The fantlies were cleselfied on the beete of soclal perticipathon and cultural behariors. The Maxican division Lacludes fenilles whlch partielpate socielly in Maxican soclety, conolder Spanloh rather than Mayo the ir language, and are relatively wre future-orlented. The Maxican with Mayo enceotry division Includes feallites whlch partielpate soelally in Maxicen coeloty, consider Spanleb rather then Mayo their languege, and conserve Mexicen rather than Mayo Identiflcatien for themelves. The difference between these two Maxican groups 
1. that the latter includes fanll1es whose heads adalt having hed at least one Mayo parent and hold som Mayo bellefe. The Mayo division Includes fantlies which parelelpete socielly In Mayo soelety, are proud of speaking Kaye at howe and church, behave as Majos and are Identifled by ether Maros as Yoremen. Also a dletinction based more on attitudes tomard naterial wealth and attitudes of advancement in the econonic realn wa discovered and Mayos were subdivided by fantlies Inte two groups on thls criterlon alone: progressive and conservative. It wast be aphesized that the way in which this term is used Implise no wre than an attleude toward walth.

A fourth group, Kayee Just turned Mextean, appeared again and agaln as en Ideal pattern but wh had no ecquelntences who wre mabers of thle category. When saked, our friends would say that people in Hunteberpo did not have tebatpo burusin because "they are Mayos tumed Maxiean." After getting to know several of these Huataberpo fanllies we found that they wore or less clearly idontified themselves as elther Mayo or as Maxican, and that those who Identifled themselves ar Mayos participated In ceremonles and had concealed crosese which would be placed in the tebat during Lent. The Mexicans with Mayo encestry of cur eqqualntence had coneldered themelves Maxican for twenty or thirty years apparently, and were obviously strongly Mexican by this tim, er wiahed to eppear so. They also hed Maxican spouses.

The flrst two groupe, Mexicane, and Maxicens with Mayo ancestry, are well typlfled by the four famllies in these categorles we got to knew well. One of the fanllien in each group was wet through a letter of Introduetion, and the other two were we in the ordinary course of the 
overyday businese world. Hene wore net, acedlese to say, at ceromonies. In order to lnerease the probab1lity of the group universality of patterns discovered in these four cases all patteras found were checked In all the other Mexican fanilles of this soclal etratum which we encountered wth any degree of regularity, such as our nelgbbore and leadiady, and so ea.

of the nine Maye fenclies we knew best, the five progreselve caes and throe of the conservative ones wre net elther at the Jupar1 or Novenarla churches whlle they were dolng Mage cerwanlal labor, and the romintes conservative was nt in the course of cur inquiring about - Mage religlowe cermeay in which he we serving. The ofnilerities found In this group were also checked in order to increase the probab1l1ty of univereality, with all other Moyo fanllies we enceuntered.

The fandlies in esch divielon were studled latenotvely and campered In quest of group patterne. Internal patterne wre dlecevered and then group patterne wre ceatrased with one another. For exaple, the cendency tomerd aggreselvemess we noted in the Maxicen group. Thle then wa checked with all the Maxican fentlles or Individuale we had oncountered and wa found to be true for the great ajerity. Also It was woted that wet often when exisls or fantly argunent occurred aneng cur Haxlean nalghbers the gullty party hed wot been assreselve enough in a business deal and had been cheated. Aleo thls tendency was noted in the Keadcan with Maye encestry. When the Maye groupe vere exculined thls condency was quite reversed. Mayos generally prefer to be pollte and get cheated, rather then to get in an ergument. Mayos shew very litele confldence in thomelves as ectors in the bus Inese 
world of the Maxteano, with an cecestomi notnble exception, and generally are very gentle. A Haye persen aneag hle own group of

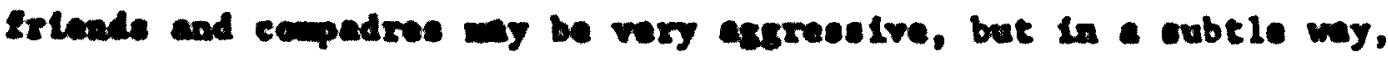
not orderlng, but ouggeeting wth f1re worde, becked up by sanctions of

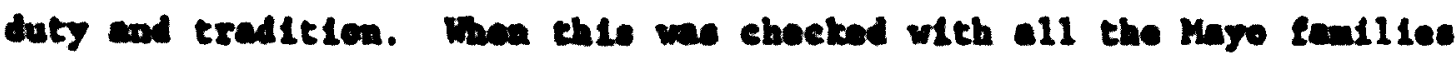
and individuale we knew, it wa found to be gonerally true. The quiet-

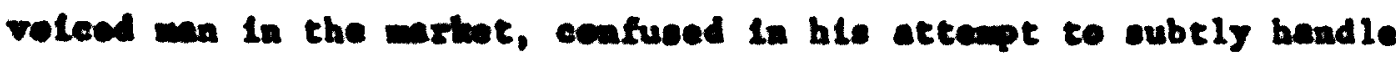
Maten currency and often puohed eslde by ocberw, very often turna cat to be Mayo.

Thus as patterns were abotracted and the three sroupe secind clearly dietingulohable, they were copared with one another, and the

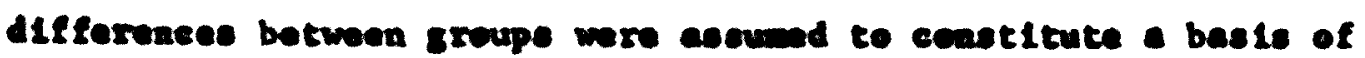
ethente difference. For this opecifle etudy it wane that people with

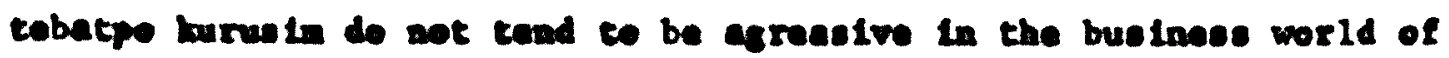

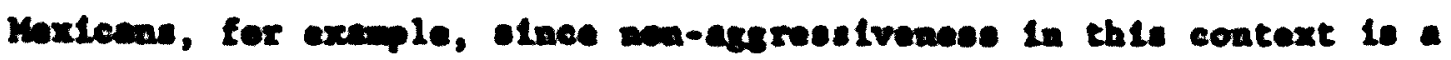

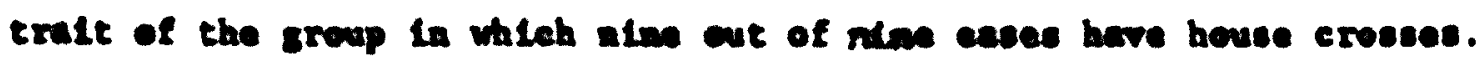
Thle thon we the nethod oelected for the enaljolo of the thlrteen fonl11es. One of the important reacen for thlo election wa to cotroy the opeedfle Ilentity of eay particular fanily. None of the efntlartiles are opectele te any fantly but are geaeral to the group as a wole. In wo case w11 I be discussing a opectfle fantly but rather an Ideal fouly generallsed frwe the real fanllies we know. The generallections have a bals in reality but are not reality in themealves.

In the following enetion the them that will be doreloped is one of contrate between Kaxteen and Mayo fanliles in terme of ooclal 
particlpation and behavloral pettems. It will be shown that the Mayo faniliee do in fact partictpate in Mayo religlous ilfe and behaviorally

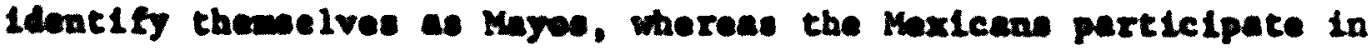
Maxican soctel 11fe. Accemlishing this will be duwastreting the peeltive correlation of the tabatp burus with kaje seclal participation and Mare behavioral patterne for Mayo fanllies as agelnot Maxican feni1100 in thle cotal suple.

Seclal Perticlacten. In exmining the secinl particlpation of the three sroups, certain ifferences are noted.

A. matlened enrlier the visiting pattern 10 oae of Mayo-Mayo and Malcen-Maxtcan exchunge. When ono is violting friende of a Mexican fenlig the Lemily tende to be Mexicen even in an ares of high Mayo populatlea. Kare encesters or en encestor ny even be concealed, or If the encestor is et111 11ving, wy be visted by only ene waber of the fenlly whe is clesect kin to hin; especially, if he is the parent of a nuber of the bousehold, is thle Individual litely to violt hin. But the rest of the fenily an very likely never go eleag. On the -ther band, pareate of Maye houscholds often live with their cons and deughters, as is the Ldeal pattern, and are grantly reopected. As we shall dempnotrate in the leet section of this study the old people are leoked upea as great asects to the fendly, and ere etrongly 1 inked with the tebatpo burue. Thle loes of reopect of yextean fantiles for thelx old people, or perhape wore accurately speaktog, thelr lose of Interast in thea, is perbape 1 inked with a growing future orientatien of urben Kaxlean eeclety whlch is flitering lnto the rural arves and ander toums. 
The Majo plalting pattern eppeare to be as ethnically orlanted

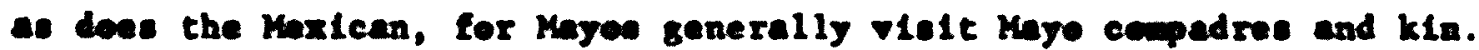
Some of the progreselve Myjos have taken Maxtcen cempadres, so som vielting mat also tabe plece betweon Mexicens and Mayos; though we never obeerved en exchange of whole fantlies in hom vielte we often eav Haye and Maxican won driaking tegether. One day we took one of our

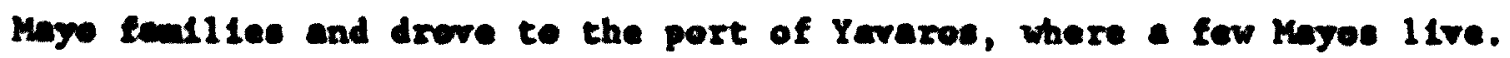
And though this fendis is very progreselve In wang wye, two of the four fentlles we violted bad obvieus tebatpo burust and during each of the violte only Majo was epoizen.

A groat mjority of Maxican social participation alght be ow marlzed In one word, balle (Spanioh: dance). The Maxican factly looks fernerd te, buys for, ettend and rellehes the dance. It 10 the an type of soclal event and accompantes noot Moxtean weddinge and flectas. On our tripe to a larger clty nearby cur Maxicen friende askad if it would be poselble fer us to bring a fancy palr of drese gleves for the deughters of the house to wear to a dance. We were teld by other Maxicen frtende how beautiful the Eester flesta at one of the beaches wa. Bxpecting a Mayo type of cercuony we were Interent-

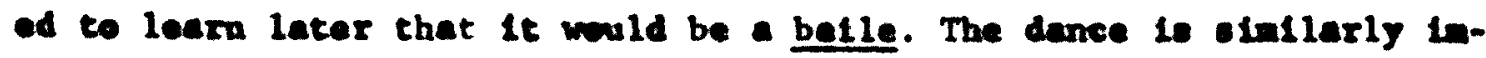
portant for Mexicane with Maye ancestry. Both groupe plan ahead for monthe for secisl dences, espectally at meddinge. 15

Prosteselve Magee else enjes dancee, attend and give thom. A11 Meyo dances we attendad Includad an altar with o ealnt and a maectre whe praye in connection with the event. Many of the wost ecaservative Mayos feel that Maxican secular type dances are bed, 
eopecially won ettended to the detrlwent of obligeted perticlpation In a traditional ceremony going on simultaneously.

Very celdom do mers of Mexican families, even Mexicane with Kayo encastry, attend Kayo ceremonies and when they do it is aolely as observers or vendors. All the Mayo fanilles we were acqueinted with ware cosstant particlpants, on the other hand, in Myo cerewonialism. Of the aine Mayo fantliee particularly referred to here, all regulerly etteaded the Friday presenstone of Lent, Holy Weok, and the pasteo en Saturiay of Glory and ranter suaday and mabers of at least five of

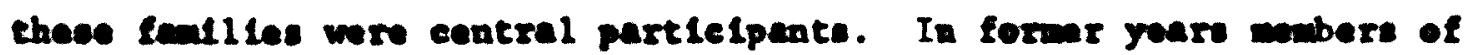
all the fandies beve been ipportant partlefpente. In 1961 ecvon of

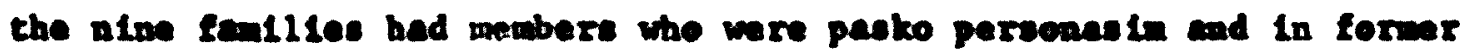
years we know for certent that at least elght ef the alne fendiles hrve oceupled thle ecatus. Probably all have doae co, but cur date fer mobert of the niath teally is not adequate en this polnt. All the

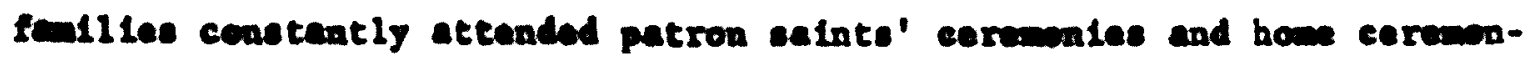
Les both in the Mayo River Valley and in the Fuerte RIver Valley. som nobere of all alme hescabolde beleaged to Majo ceremealal

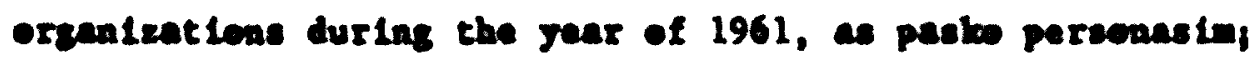

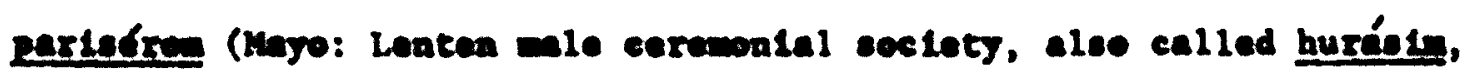

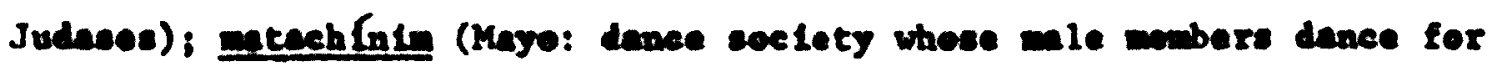

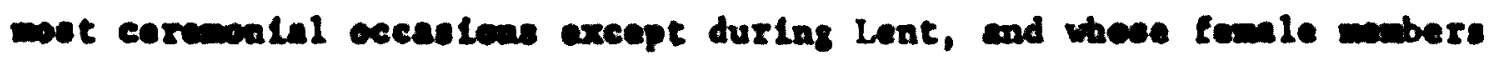

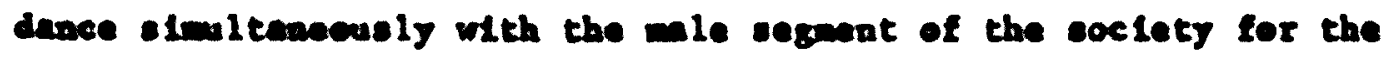
cercuales of the santioln TLnLren and Esplritu Santu in the oprtng); biht Marfen(Majo: women end ehlidren having certaln roles in the Leaten ceremalea); or as bobenárie (Mayo: church offletale er puablo officiale). 
So It to net diffleult to see the difference in sectal

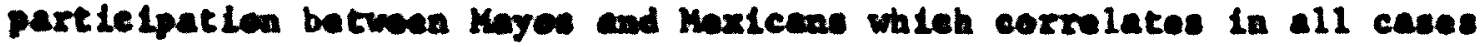
when the exlstenes of a tobatpe burus.

Mere Behorderel Pacteras. The high value for the wee of the Naye

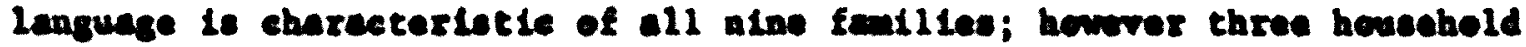
heade of the progreseive grup do not spack flawlese Maro. In thase three houcaholde Mye is definitely preferred by other mabere whe opark It excellently. In the feur censervetive boascholds Myso is definitely preferred; in one of these wo nover heard one word of spanich and In two the SpanLeh, wen beard, is oubstandard. The Maxicans and Kaxleane with Hays aneestry definitely profer Spenloh and conolder It

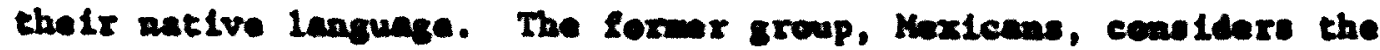
opeaktan of Majo very guatut and terribly fump. Other nembers of the Hexican with Mayo anoestry sroup bove a real fellowhlp with the language and enjog opeaking it won it is not to the detrimet of thatr idontifleatien as Maxicen. Thus fanilles with tobetpe buruct profer to opeak Kaye, however the progreselve ones are In sema caves equally at hom In Spenish, espectally cam of the younger mubers of the housebelde. In the Haye ceneervative group a patterned fenr of etrangers was noted, which is anifest in the chlldrens' heving fear fite, and the adults' sooking with the left band, eplteling and refusing to face or oft with their left eldes exposed to the etranger. In the prosreselve Mayo sroup perente would proudly way, "Leok at that child of alne, he Ion't afraid of etrangere." In the two Maxteen groupe these feare are not manifest usublly. Noverthelese opitting ean be otimulated in Maxleans with Kajo encestry if, during social interectiea with a Mayo 
the Kaye constently opite.

A great difference with regerd to the geal of educetien of chlldren exists between the Mayo and the other two groups. The fanllies of Vaxicans and Maxlcans with Mayo ancentry are ortented arvund the scbool educetion of thelr chlldren so thet the chlldren will be able to "get ahead". The perents were very proud to wation that their children want to learn how to raed, to learn Englibh in partleuler. Mageo aleo want thelr ch1ldren to learn bow to read, to bhow that they have "good heads" and are Intelligent. But this does not man they wat then to learn Maxicen culture or to get aheed by making a lot of woney and boepIng it for themelves. In some Mayo fentlles the chlidren ere expocted to opeak Haso at hom though they learn to read Spaniob at school. In -there seme children are opoken to In Spanloh and are anld not to be able te openk Mayo. Howrver they are et111 appected to ect 11ke Majos, and to know thelr cerveonial roles when pertielpating in coremonies. The meture Mayed were the ones who cane to us oincerely manting to learn Bnglioh, and really eften putting houre of work into it. This 1. In contrast to the Mexlcen parents who were generally not Interested In learning Engl Leh themelves, but wated their ch1ldren to speak $1 \mathrm{t}$. There 18 a degree of difference in the tim erlentation of Mayo and Mexican culture as it is sound in Northwest rural Mexico. The Maxican fenily there is working for a botter life for temortow, working for thelr chlldren, for the youth so the next generetlea w111 hove comthlng. All the Mayo fandlied that we know were not particularly or certalaly not chlefly ceacerned with these netere. For then the greatest eaint or the not reopected persed is generally the oldast. 


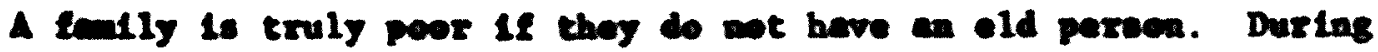

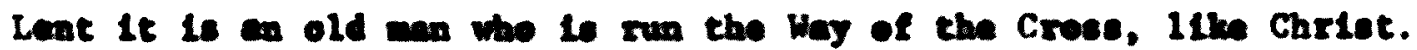

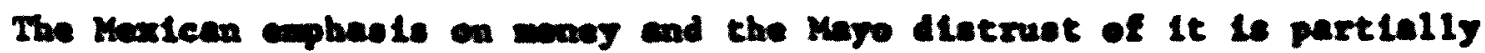
explatiod when the two the orientations are reallzed. For Moxiceno many 15 the road to a bright tuture. For hayos a graat daal of aney elply mene the posecaser has in ell probablilty sold bimele to the Devil or at least bean in league with durt poners. As coe of the fendiles put $2 t$, in referring to a large veble ceresmony at which were hundrede of vendore in the churchyard, "Much waer foll within the tour corners of that boly ehureh ground, and It wil not cem cat right for these whe oold there. That is the plece to give," (1.e., not to oel1). Also the fear of etrengers alght be leterpreted in torm of fear of chenge and ebsence of Interest in the future es ouch. Fanflises wlth tebetpo burus in thos, opeak Mayo, have patterned fear of otrangere, went thelr chlldren to learn yayo and ealy emough Spenlish to get aleag, and are not tuture-ortented; in other words, they are Mayoe.

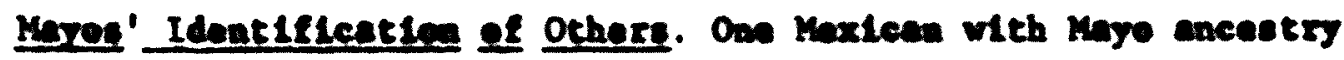
definltely Ldentifies fentiles with bouse erosees as Mayo, and when

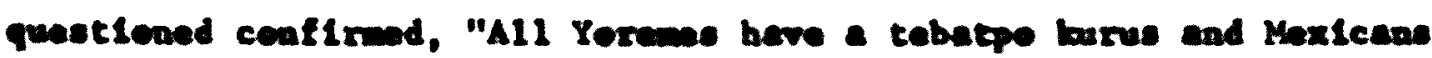
don't." One Maye friend Identifles the hering of a tebatpo burue with belng poor and with Mayo-mase. When aobod about a cartaln fcally in Heataberpo who appears to be Maye but to heve no cress, he enowered, "Yae, they are Mayoe and thoy have a tabatpo burus. It 16 up in ramele and at Lent $1 t$ will eome down te guard the house." Another

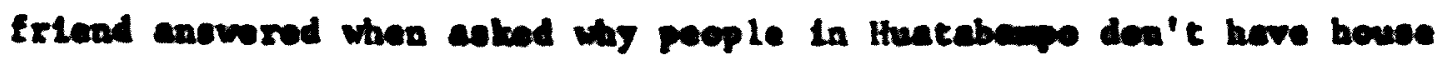
crossee, "I should thluk wot, they are Mayos turned Masican." 
And a third Maye anowerod when aked wy poople Ilving in Huatobenpe had no house crosene for the not part, "Mexiean 11 ve thare."

"Are people whe have no tabatpo burue semet ines Yoremen?"

"No, they are not Yorman if they don't hove e cebatpo lurua. At time Iibe Lent they cen dom to guard and then ge back up.

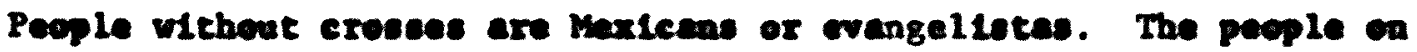

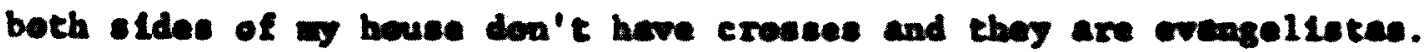
They any thoy don't die but that lon't true, for I ear one die. It is just a bellef." Thue cur kyse friende conider other feallies nea-kaye if they do not hove a tebatpo burus.

Maye ecelel pertleipation, culturel behwior potterns, and Identilication of ether Kayea, all posttively corrolate with the artetence of a tebatp burue and tte culcurally patterned use. 
V. THE CULTURAL CORRHATES OF THE TEBATPO kURUS

The tebatpe burwe in lte culturel context refere te the crese es a asbel in Kaye thowght, a sybol with a body of definite mantng

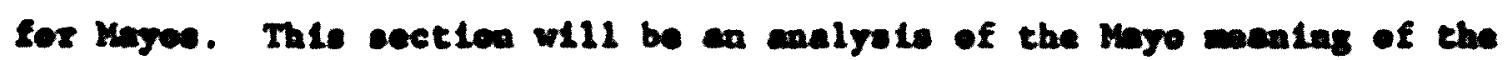
tabatpe buras and of the linkage of this crose to kayo ceremonies and

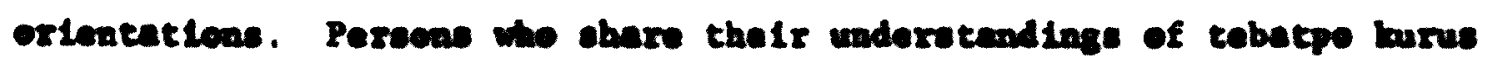

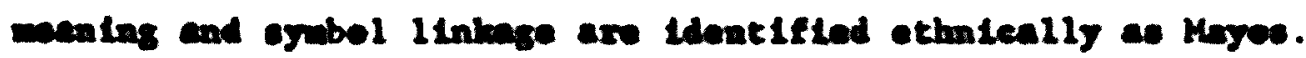

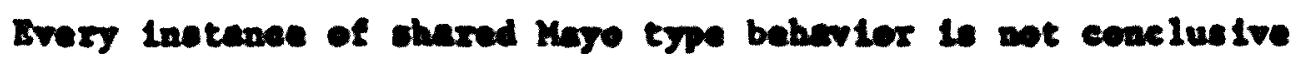

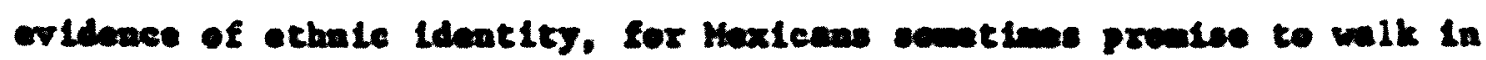

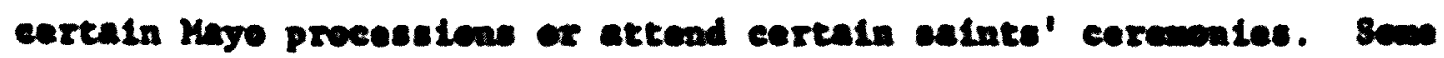

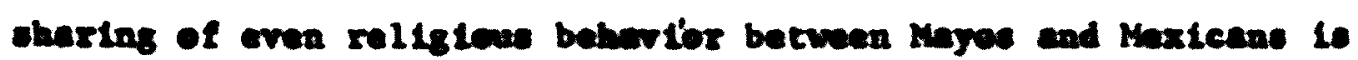

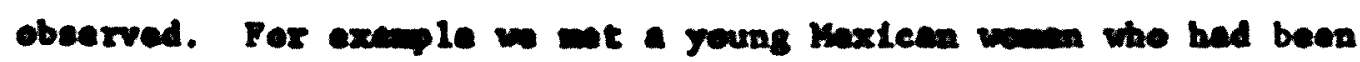

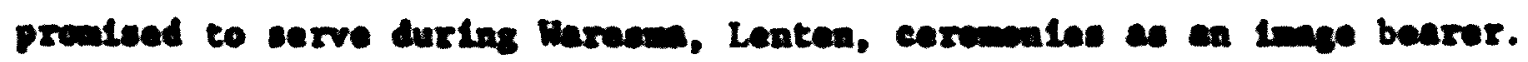

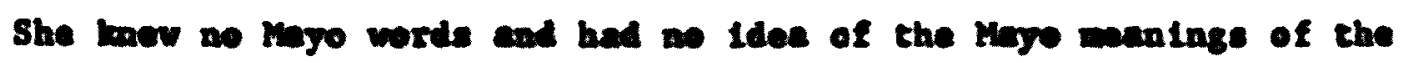

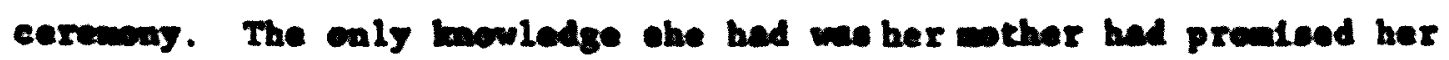
when the had beean 111 frow e fall ad the had to sarve. Mexteans

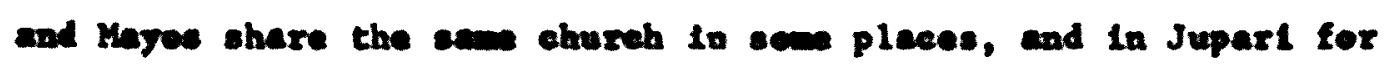

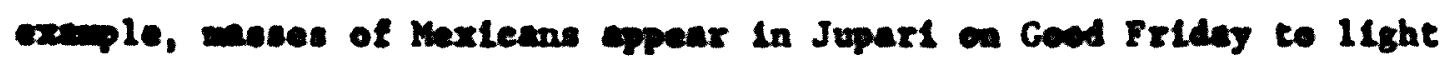
candles and wik in the proesetes. They sey can w11 be cured or a who w111 be granted if ane carries a lighted cendle in the proceselon that night. All partlelpetlag Hexicans do not, hawver, obere the Mayo oybollew and bellate abeat it.

An understanding of Mas ethale Identificatien ase therefore 
be based In an underetending of Maye beliefs and oybolions. What the tebatpo burus provilas tor ethnic Identifleatien io a hendy phyoical Indieatiea that som influential memer of the bousheld identifles himelf and cen positivily be ldentifled as a mber of the Myo or Yorene ethnle eroup.

This oection 10 a eseription of the tebatpe burve as a oybol Is Yorwa thlakling. Read ba ald (1955: 18):

The ertiotic cetivity alght thervfore be deecribed a a cryotel11zatioa, frw the worphew reall of feeling, of form that are igniflcent or oybolic. On the beste of thio setivity a ' eybolle discourse' becene poselble, and relleten, philesephy and selence follew as ceavequent weder of thought.

Wh are not here cencerned with ertiste ectilty at the ergetulling agent of Maye "ogbolle discouras" but with the tebatpo lurus as a sybol or cub-oybel of Mayo "osmbolle discearse". Our studles have developed Read's Ila and show that form or symblo do particlpate In a Alotinetively Mago "symbolle dLcourse" and in this partielpetion ereate a Mre milglea, and poestbly en incipleat phllowophy and selance, although the religleus oybollen 10 the prinary Interest here.

Thle section is an attempt to analyze the tebatpo burns as a

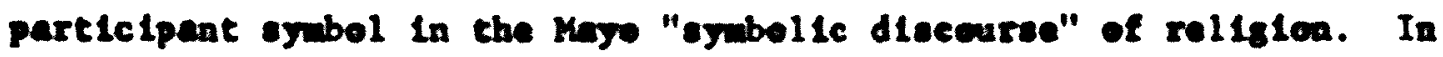
erder to exmine the dietributien of the tebatpo burus in this discearee two etcpe were taked. Firet the essocletions of the tebetpo burue wth

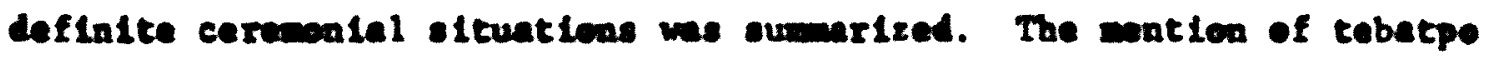

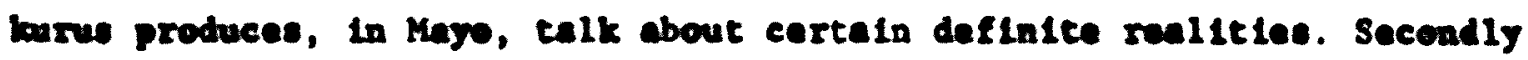
the tebatpe burue was exentined as an aspect in kayo orlentetloas. The matica of the wrd to a frlend during a chat seldon produced eny 
celf-coneclous Inforation about the crose Itself, hewrver it mald produce a eltuation in which the chain of thoughte produced by the word alebt be partially examinod. In this way the linkage of ethor'concepte te the tebatpe burue could be dlecovered, If the pereen chose to wy anything at all. In actuallty probing for informetion about the

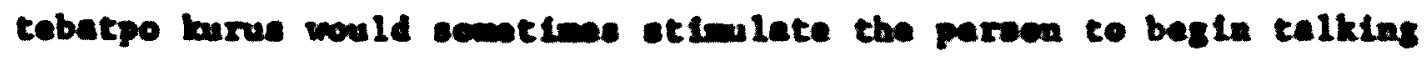
about Wareeme and the ruming of the 'ó'ole (Kaye: eld man), for exumple, or the ceremeay on the dey of sen Igacelo, or eroseces in the cemtery and funerel earvices. This thought asecelation wen then

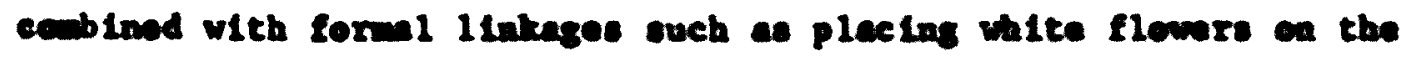
tebetpo burse the day of the seata kurue or red flomers for the day of

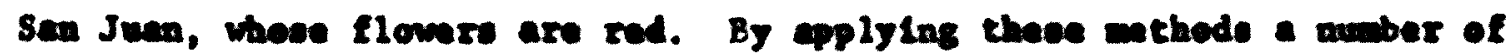

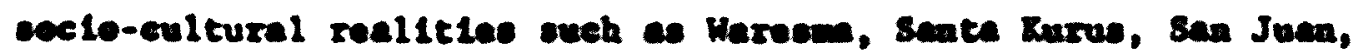
Sen Igmacio, and Toder senteo ceremoales, were discovered to be eystemefeally 1 Inked to the tobatpo baxws. Since may crosecs are

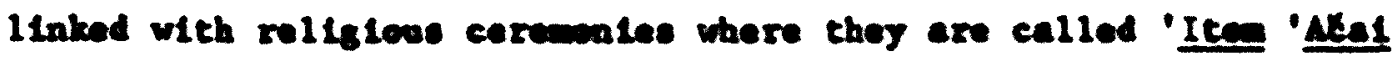
(Kayo: Our rather, alee reforring to Chrlet, to the Santiolme TIniran,

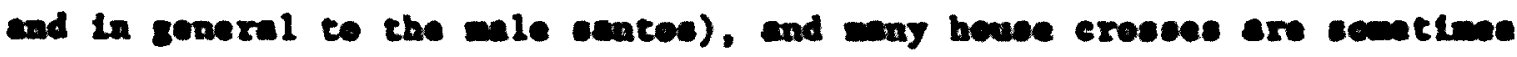
celled by the ene tarn, howes crosses are thoreby linked to all these cermonies in a conslstent and patternod manor.

Secondly, the formal and functicall IInkages of the tabatpo laurue nake it part of may Mayo orlentatione. The function of the boves crose will be discussed in relation to the orfentatione and Intereate of the old peeple, certenenlel labor, peskole arte, experantural power, the land, and the cult of the dead. 
The Tebetpo Kurus Linked te Ceremoniel Realitles

When a Mayo sees a tebetpe burue or It is matloned, what

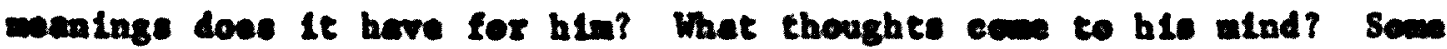
of the aseoclatione the house erose bringe to his alind are activities such to the procestion of the visiting ealnt around the crose during a bevere ceremony, or the knocking dowa of the expes during Holy Week. Other associations with cerrmentals were observed as formal ilnkeges. Thle section w111 describe sem cerenonter and the linkages of tebatpo burust to thom.

Wereege. The formal IInkege between the tebatpo lurus and the Waresur ceremonles is very etroag, perhape the etrongest linkage of this erous to any Mayo cercuonial complex. Mention of the tebatpe burus to may Mayos, and even to seme Mexicene with Mayo ancestry, bringe soveral kinds of zesponse connected wth Lent: "The erose guarde the house.

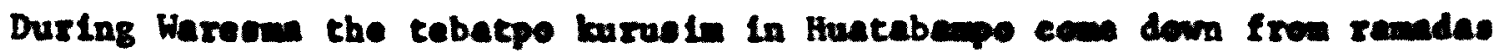
to gunird the houces, and then ge beck up." Anotber ayse, "Crosses are te be decorated for eatate' daye or at Vaream." And et111 enother polnte out, "They knock down the tebatpo burus during Varesm."

The Lenten ecason at Jupari Involves seven weks of couplex Maye ceremontal leber. In rough outline it is elndiar to the Yaqui Eester cereweny as deacribed by Splcer (1940, 1945), and Palnter (1950, 1960), and to the Navejec aree cermonies as described by Beals (1945), though there ere ipportant differences from all these deseriptions.

The first elx weeke ny be sunerized a Including som elx proceselons, taking place each Friday afternoca, and ending just as the oun sete. Holy Week elimares the cercmonlals of the eceson. Early 


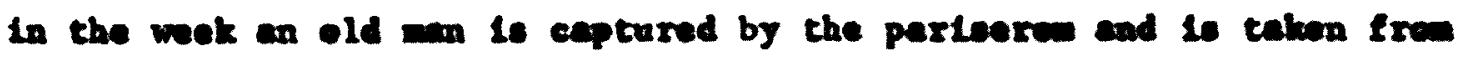
house to house to collect glfte for the coning cerwony. On Wednesday erening a service is conducted in the Church and on Thuraday afterneen the old man 10 run around the church by the perteerem. Prom early Friday morning at abeut four •'clock unt1l Saturday worning about four the cebatpo burusin, the church crose, and the senta kuree Inolde the church are all knocked down. Fridey aftarnoon Chriet lo eruelfied gymbellcally. Two proceselons take place that evendos, the elret with Christ in the bler and later when Chrlat and Mary mot. At about tour In the worning Seturiay Chrift arises, the eroesed are set up and the

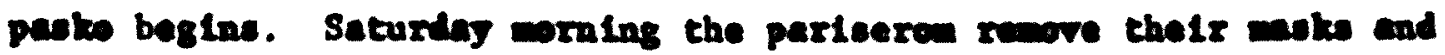
boceme men agaln when they are beptised. Sundey morning Chriet ceme to woet Mary and thes return to the ehurch, thus ending Dareesen.

The flrst palbirte (Koyo: woy of the crose), is eet up the Flret Friday of Varasma and each of the elx Fridaye in the moning the ble (Mays: path or reed) lo owpt by the pasko peroconedn. Thle duety kalbarle consiste of thirteen single erosece going tomard the river in wre or less a strafght $1 \mathrm{~lm}$, wh three eresces at the fourteenth

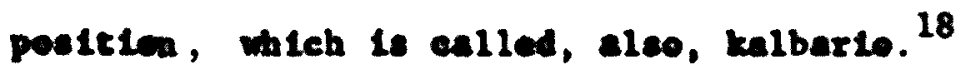

The tebatpo butwe bee arverel defintte 1 inkages to these weeks of Intonse ceremonleilom. It is formally and fuoctenally related to

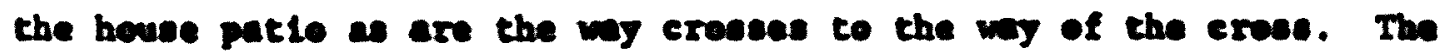

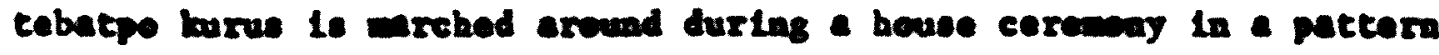
- Indler to that in whleh axe the erossee of the first way of the erose during the flrot alx Fridaye of Lent.

The tebatpo lurue and the erosese of the flrat kalbarlo are 


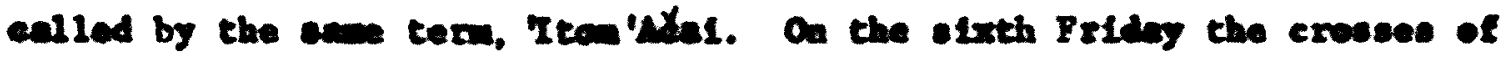
the flrst wry, and the nent mok, the old an and the tebatpo barusta,

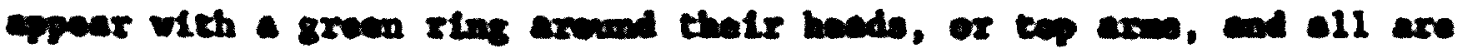

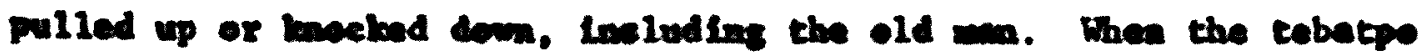

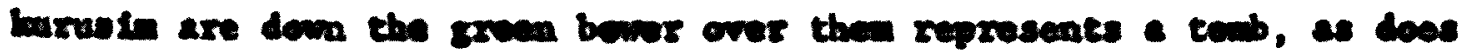
the grven bomer over the exwase of the secoud woy of the expes, leisertbed below in comecetien with the ectivitios of Thuradey of holy Weok.

All the kalberto exomes are prayed before, is the church croas, the paskola rumela exose, and the tabatpo burualm in the past.

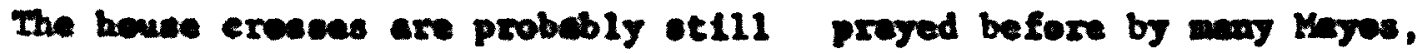
chough thle we not observed, except in the cesse of paikbles at a house parko.

Bech of the alx Friday processions is a little difforent.

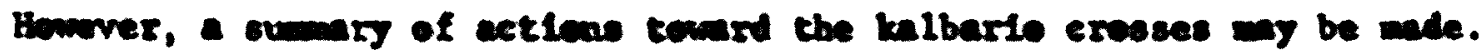

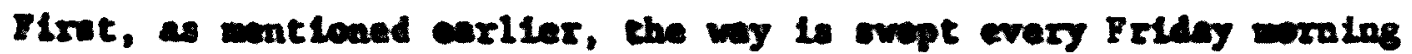
before 1te uee, just as is the ehurch and Ite patio each sumdey, the

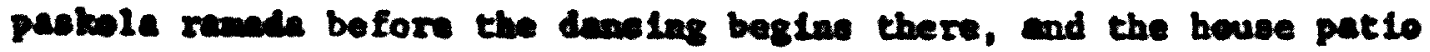

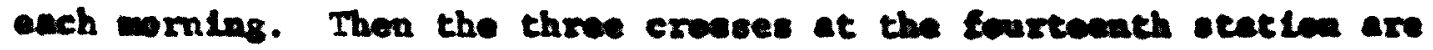

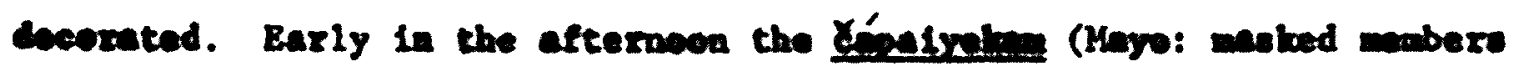
of the partoereal begin to form, run aroved the ehrurch and then stt down beslle the ehurch to sest and relex. Often durtap the running axeand the church a Ilne of Xapalyeken stop at the flrst cross of kalbarto and each in his turn beake up to tho exwes and pretends to defccate on 1t, thus ehowing their raspet for the erweses.

Late in the aftaraoen the proceselom begims to form. Boon 
FTGURE 4

THE SACRED WAYS OF WARKSM

JUPARI PUEBLO, 1961

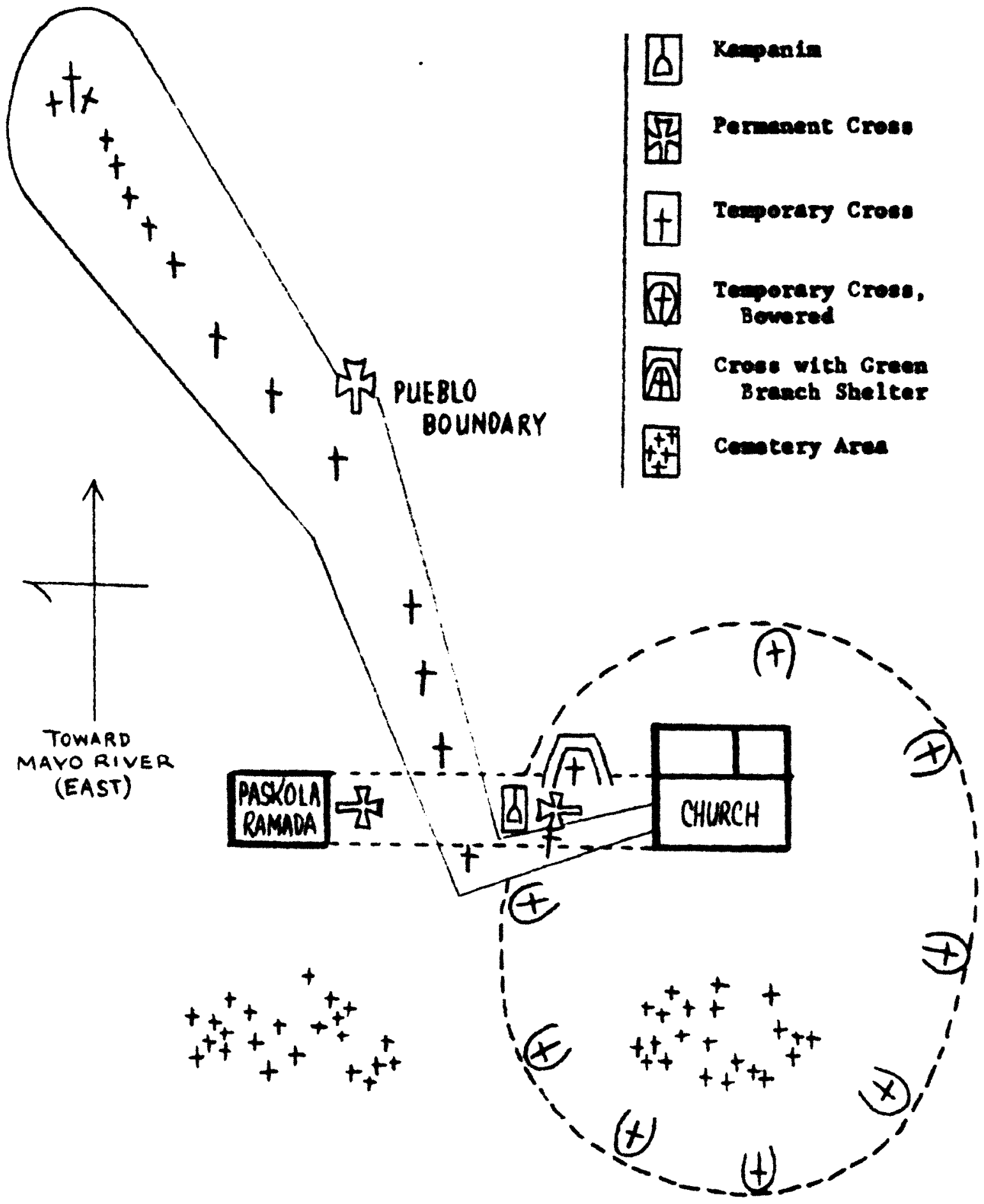


three 'alawasim leave the church ahead of the rest of the procession and proceed to the first kalbarlo crose (station number one), addreselas the cross hy walking around it two or three times in a counter-clockwise direction. One 'alawaeln stays with the croos, guarding it fron the Eapafyeka by placing on 1t the butt end of a short lance with a metal tip and with ribbons on the etlek part, hio Inolgnin of offlce, and holding in his right hand a loag owitch with which he strikes eny Eapalyetere that cone too close. The other two 'alamase continue to the socond cross (otation number two) around which they sarch. One guards thls crose and the thind goes on to the thind crese (otation number threa) which be circlos and then guards. When the proceselon leaves the church the 'alowente march eround thelr reopective crosese three time in a counter-eleckwise direction, and contime greeting and guarding each station croes in the seme way, untll the processien 1. four crosses away fren the throe grouped at the last station. No the procesetion woves cleser the second, and then the third 'alawein, reaches and marches around kalbario, the fourteenth etation, the eacond and third 'alewes in being jolned by the 'alavestn or 'alawes in whe arrived before they. Finally when the procesetion to one crose away from the last station all three'alawas in are guarding at the last station, one at each crese of the three crosses at the station. When the proceselen noves to this kalbarto these three 'slamas in march around the three croseces two or three times and then return to the church.

During this tien the procession itself has been golng through ections at each of the croseses. As the proceselon approseched the firet 
crose a packo persona set down a nat in front of the croas on which the flomers mere placed. Alse at thle time the rest of the pasko personenif were sarebling around the crose three time. Then the pasko peroenas in stepped to the alde, crossed themeelves and knelt. The Lages carried in the proseselon wre placed with thelr backs to the cross and a sort service we beld by the church 8 roup and bahl Karlen and these peoko personasin. When the chureh greup eervice we over, the pasko personas in agein marched around the erwes three times, the 11ttle chlldren throw flowere, and the proceasien continued on to the next cross where the sam pattern of marehing teok plece.

When the eervice was over at the crose just before the last kalbarto everyone ran as fast as he could to this last station, the wo and women of the puable gotag around the threa crosese In counter-clockwlse directien, the sem direction se the 'alavalm, and the tinges and church group golng in the opposite direction on the Instde of the circle. This curroundiog of kalberio is called kentl, and each Friday ceremony is celled by the same general term. A long eervice we held at the three eroses, then the proceseton, having marched around kalbarte, returned to the church, etopping for several short eervices along the wy, one of which wa at the pueble boundary cress, almost at the mowent of sunset.

Th1s wethod of eddreseling the cresees 1 inks to a wore couplex wy of ourrounding the tebatpo burus at a house cerenony and at the pakkla ramada cross on a eatnt' day ceranony, described below In cennection with the Santa Rurus cerewony.

The alxth Friday is the last proceston or Giteop kont1 (Mayo: 
last ourreunding). After the earvice ot the last etation the pasko perconacle pulled up the exwenes of this firet way of the exose.

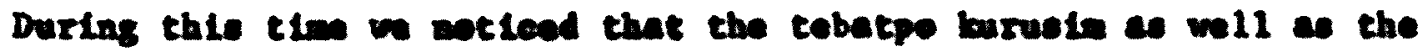

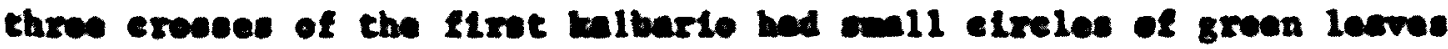

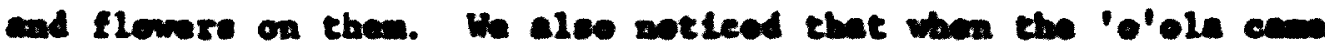
Hoday of Holy Wook, in the eustody of the parieerson, eollecting sifts

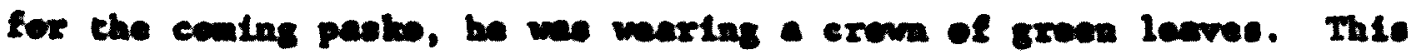
then, ropresented a formal 11nkese batween the firet balberto, the 'o' ola, and the tabatpo barre.

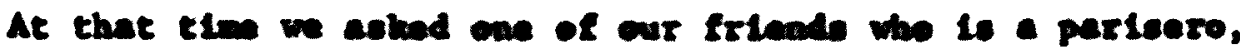

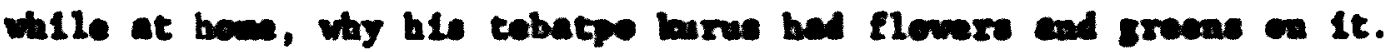
And be enowered, polatios to his erees, "That is the old man, 'Iton'Alat.

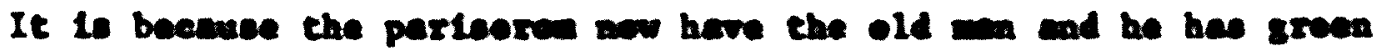
1eaves arwend his boed. When they throw down the 'o'ele we all everywhere throw down all the tebatpo burualn."

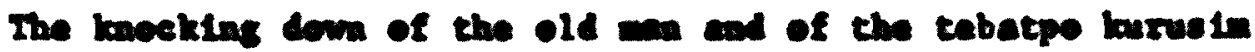
apaers to partielpata in the ene oybolle set, though the twe evente

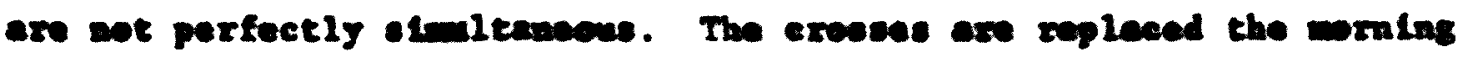
after Geod Iridey then Chriet axtens. At thlo tim, wa of the mobere of the fondly where we were opending the alght cald, "Itom'Atal hes eriven!"

On Thureday of boly Woek in the late aftermece the 'o'ole weo becked doun. Bight ereeces, or the seeend kalbarto, were erected

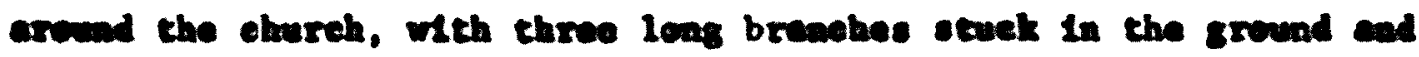
torning a bower over ench of the exoeses. Ales a exoes with a larger

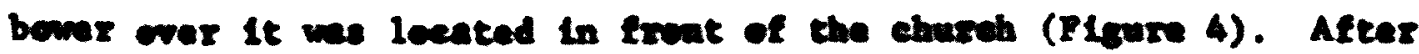


the old wan was taken to the larger bower in front of the church one of

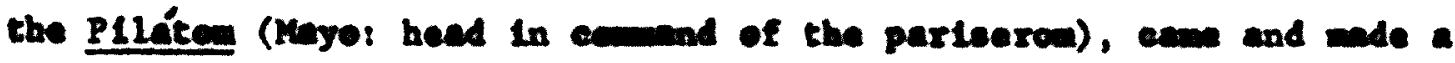

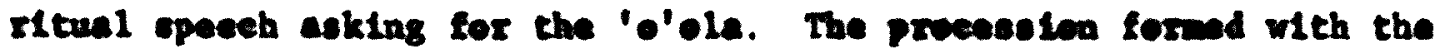
'o'ols in the center fleabed by a lise of Plleter and Xapalyolom. HLa

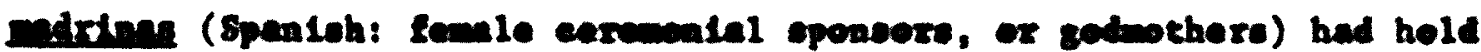

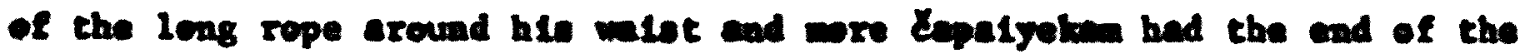

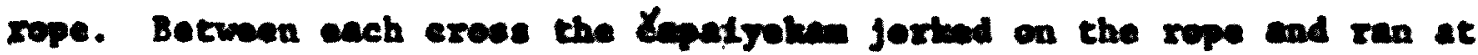
the 'o'ole, trying to boek hin dom. The nodrines protected the old en by holding olact in the rope und by beating off the Xepatyolon with

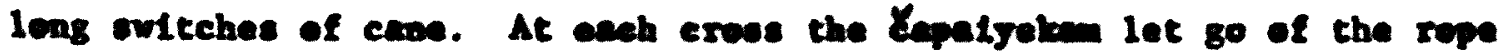
and the old man knelt instele the boner with his beck te the crose. The 'e'ola wa never ectually boctide dom lor the andrians protected him. And as the proceselon returnod to the chureh, It wa sald thet the 'o'ola had now been knockad dowa noverthelese.

Eerly Fridey noming the parteerce ran to 11 the heases lnocking down esch tabatpo burus, the church crese, and the sante Rurus Inelde the chureh. Eech bonac exve wa late fece up with the polnted longer ond comard the house, on a modem box whlch was pleced over the bele where the and of the eroes had been placted. There were four large

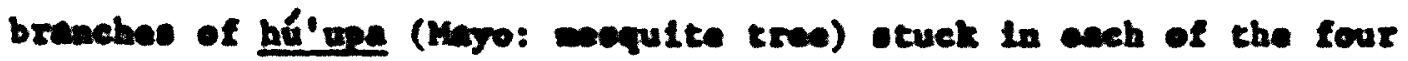
comere of a square area and tled together in petre, forming two arehes wer the cebatpe burus, wth sldes of the egunes belne parallel with the

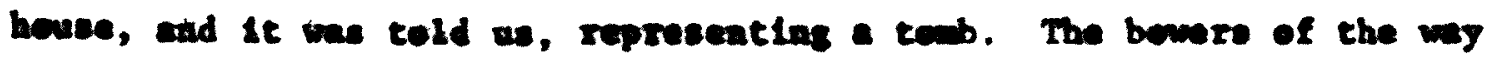
where the 'o'ele man eles represent tomb and the rope arwund hls walat ropresence the wlbóes (Nayo: belt) by which bo is lomered inte the grave. Our frlead also told us that at the tim of a death or the ceremong one 
year after a death coe tebetpo barus is used with four peln branches arched over the crose, being tled together ferming an arch on each lde of the house crese. The tobatpo kurus 18 not bnecked down for a fumeral, however, he says. This tuneral decoration to also coustered - conb and thes 1 inke the second balbarlo, or woy of the cross around the church, and the ruming of the old mn, to the cebatpo kurus and the bowe aspect of the funeral earomoay.

Early seturday worning thls second way of the exees was removed. Then early sunday worntag the third sacred way wa amept and 1 ined with green tree leaves. The chureb erees and the peskole rande crose and che green lexver mrked thls secred eren in which ling and the risen Chrlet wt. In the discusetea of the satielm Tintran cermong a indlar sacred wy wil be descrtbed fren the house were the inage of Ispleticu santu we resting, to the elureh. The decorated tebatpo buxus of the house, the chuxch crese, and the colored strenners along the

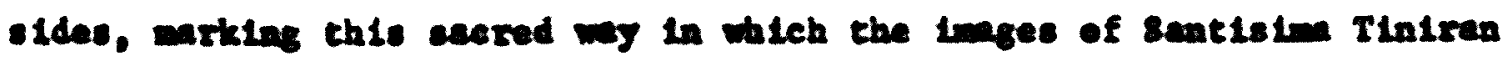
and Bepiritu santu nt, 11 luatrate the principle in et111 another context. As the opposite ends of the sacred wy in repeated contexts, the

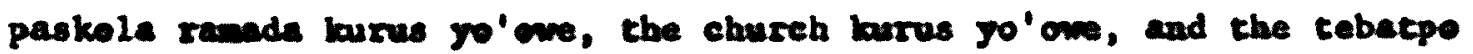
kurus of the bouse are 1 inbed.

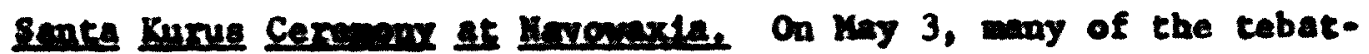
po larusin are decorated with whte flowers linking then to the Naromaxia 8ente Karus, composed of mite flemers, and to Ite cerenoxy, which wo observed on May 2 and 3, 1961, at Novennxla. On May 2 the sacred way trea the church to the packola raneda was mept, the paskols ranada ecoss was put up, and the colored stresers were placed along the sides 
of the wy. In the oventeg tow laxge flreworts axe bleseed and sat off.

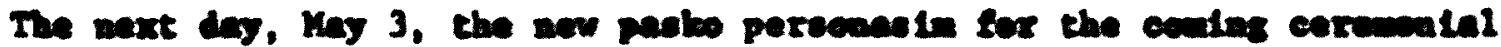

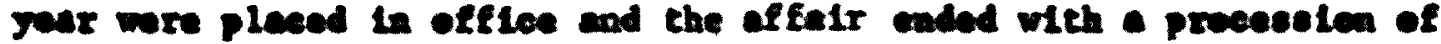
the sante karwe around the chureh.

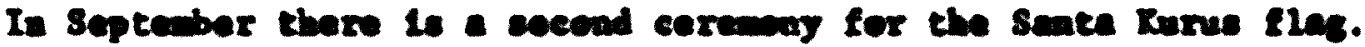

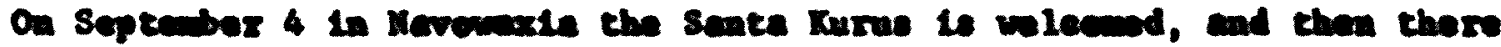

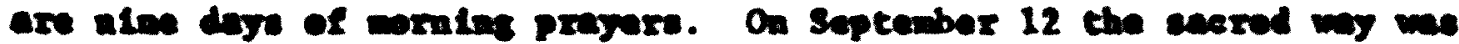

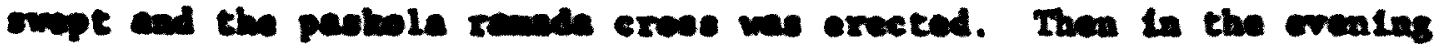

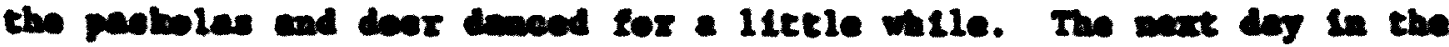

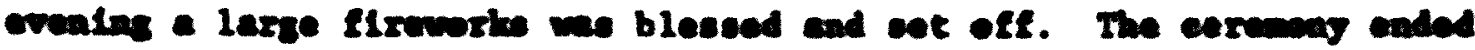

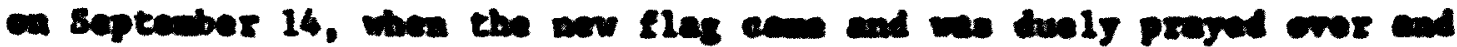

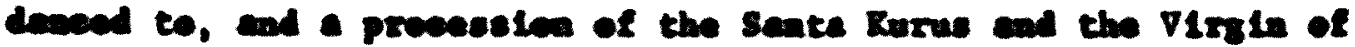

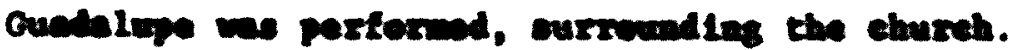

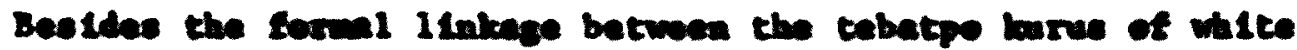

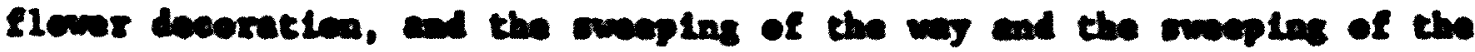
bove patle, other linkages wre observed. Both the sente kurwe ond

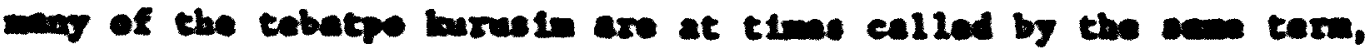

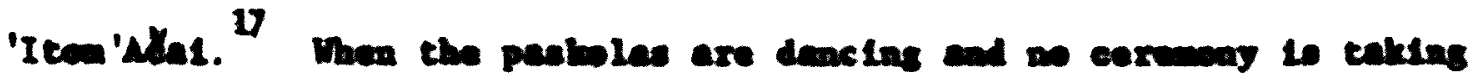

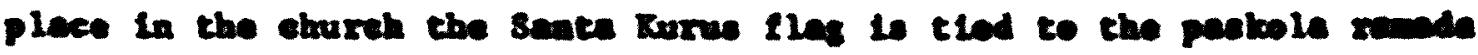
crove. The erves is enld to guard the theg as the tebetpe barne is eald to gand the bousebold.

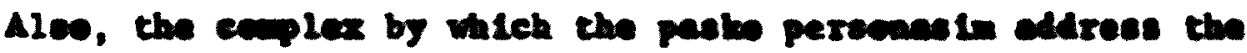

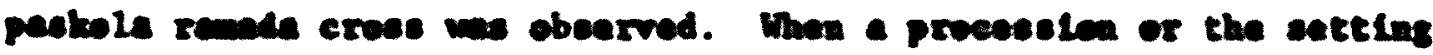

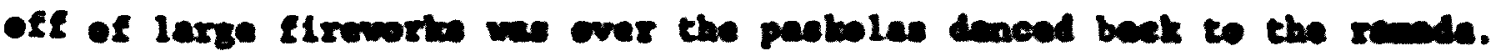

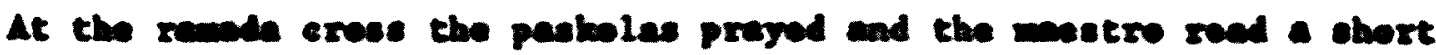
eervice. Then the paots pernenast lined op bealle the erves, the 


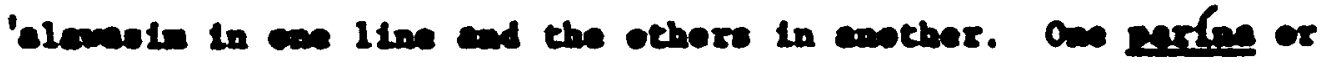

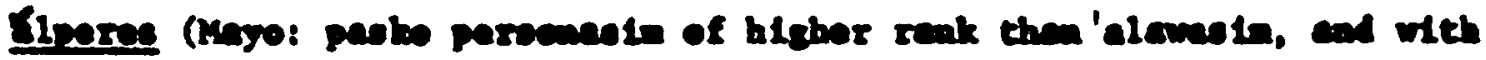

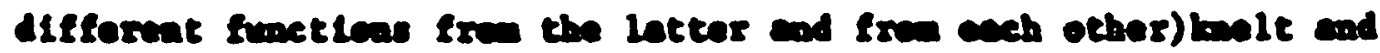

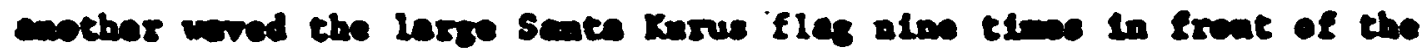

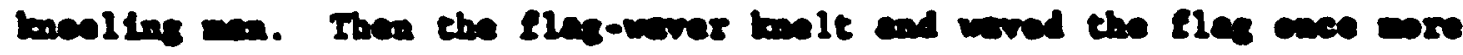

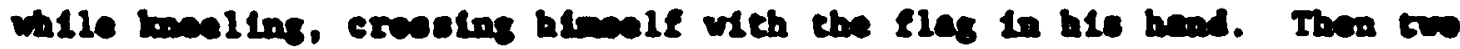

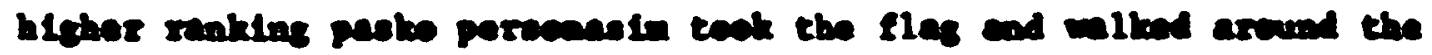

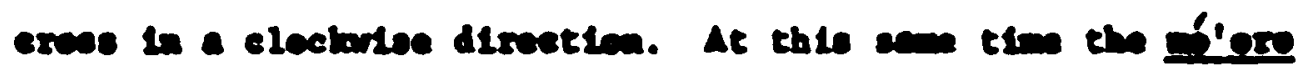

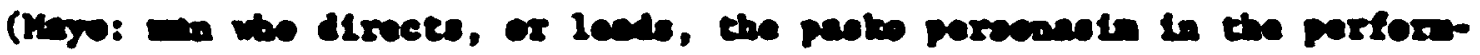

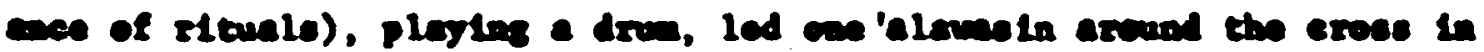

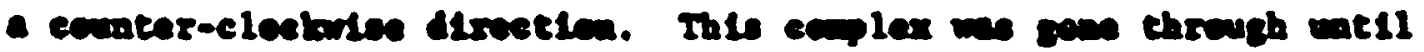

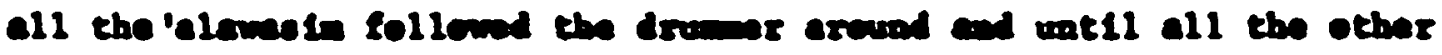

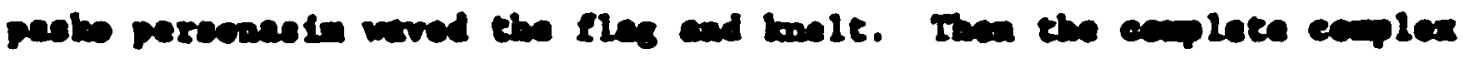

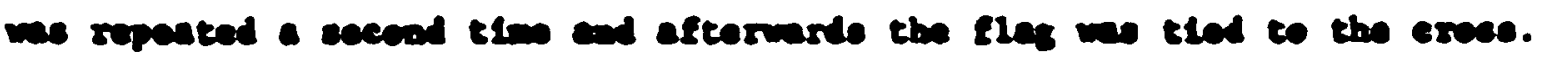

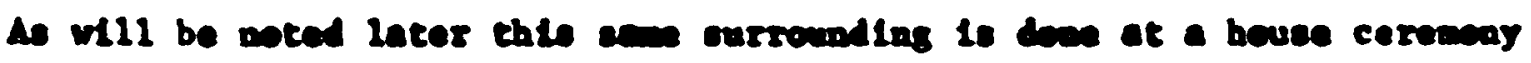

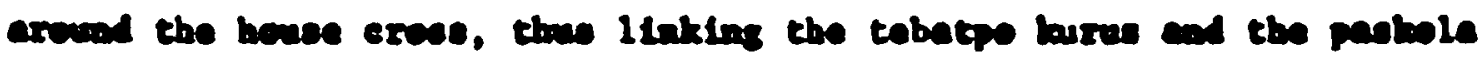

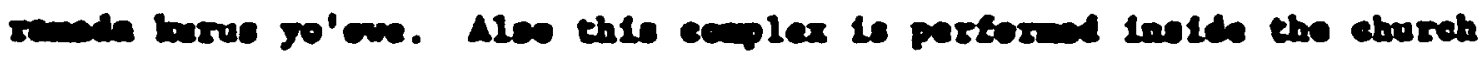

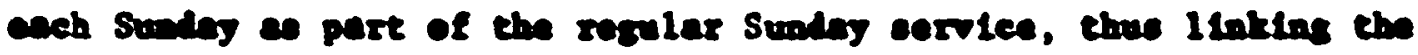

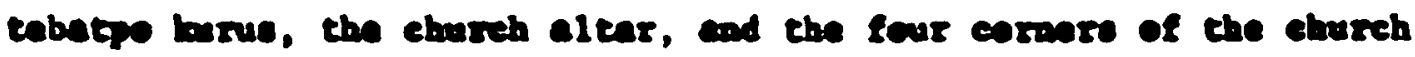
ground with the bouse tebet.

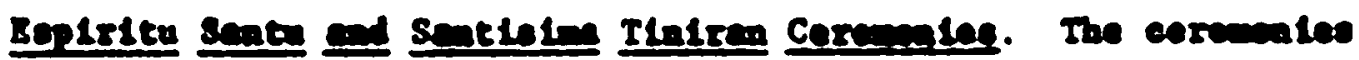

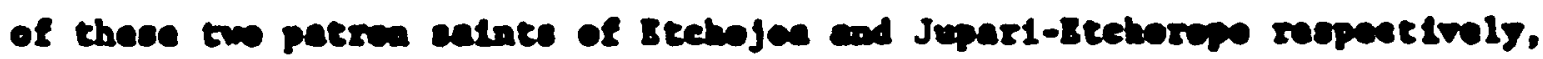

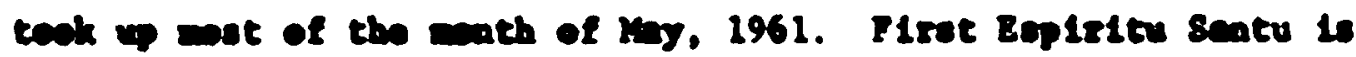

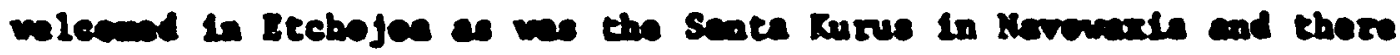

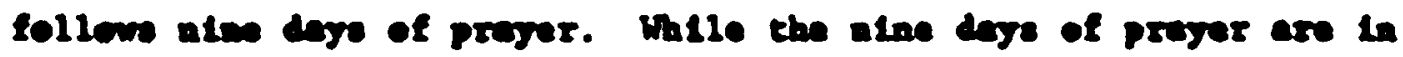

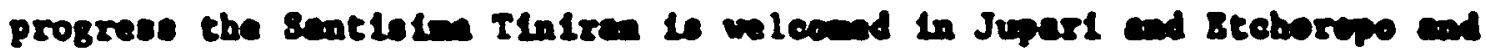


nime laye of prayer begins in those two pueblos. Then the Sentialn TIniran Inage is carried to Etchojoe for the Eaplritu Sentu pesto the flret week-end and the naxt wek-end the Bopiritu Sentu inge is cerried to Juparl for the Santiolin TInlran pasko.

The tebatpo buxus to a functloatng part of these ceromoales.

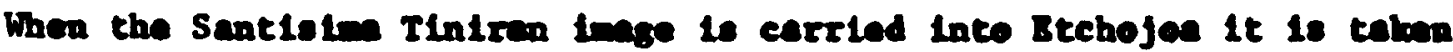
to a house to sogt. The bouce is decorated and has a tebatpo burue. After the inges are pleced on the altar the pablo perconatin conclude th1s chapter of ritual with an axereloe and the the flage of the

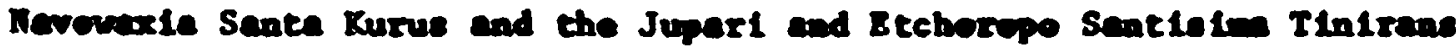
te the tebetpo bures. The Etchojon area pasko persenen in return with their three flage te the ehurch. This currounding with the flage to loag and quite copplox considering that thare are olx different sete

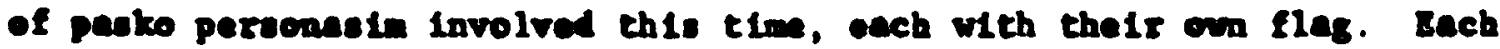

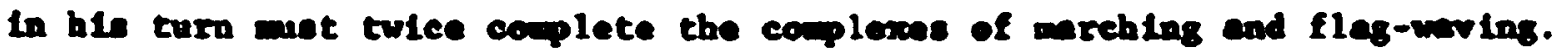
In Jupari this eam pattern roceure when the vialting Eaplritu Sentu inage is taken to a hem where it is pleced on a how alter and the parko persomast do the exercloe eround the tebetpo burus. This how to IInked to the chureh by a wa IIned with colored paper etracure.

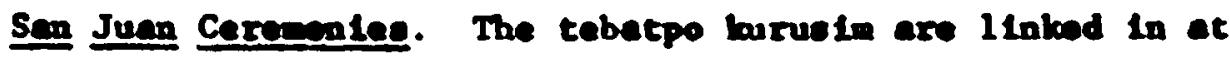
leset two wase with San Jum cerconies: flret through the use of red flowers and second through the attendence of the inge of San Juan at bouse cervmonles. Several wete before the Jupart cerenoay for Sen Juen there wee a bouse paske at which an Inage (not Jupari's) of Sea Juan attended. Then on June 23, 1961, the cervious for Sen Juen wae held In Juper1. Early In the worntag the Jupart lnage was carried to the 
river just belew the troe with the crose under it, wa beptised and then returned to the chureh.

The anin 11 inkage of the tabatpo burus to thil part of the Ban Jum corenontes is chrwagh rod flowers which belong to Sm Juen.

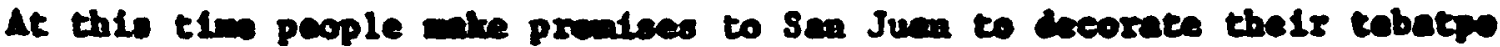
busulin with red floware.

A house parte at whieh Sen Juan ettended we ebserved. The tebecpo burus of the houge, hownver, wa decerated with lasge witte

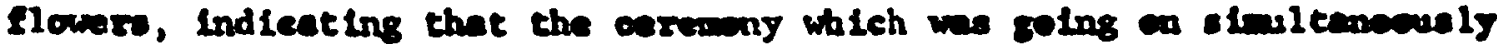
with the pubblo ceremong of the Santising Tinirm, wa not, perthen, entiraly in bonor of $8 \mathrm{~m}$ Juen. Eariy in the ovening the lange of San Juan we earried to the house. The head womn of the houschold vent to the tobntpo barrus to welceme Sea Juan. The Inep bearers marched around the tobetpo burue three thes and the bead wonn of the houschold took Sm Juan in ber erm and carried bim to the altax. Later in the evening the paskolen and deer dascer arrived. After proylng at the altar they wat to the tabatpo burus where a plece of

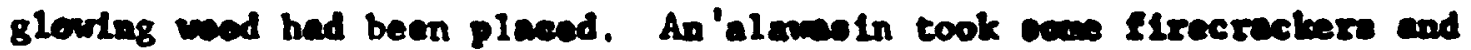
wde the sign of the croso in front of the two pabbolen and gove all the pastoles and the deer deneer som of the firecruclers. Then the

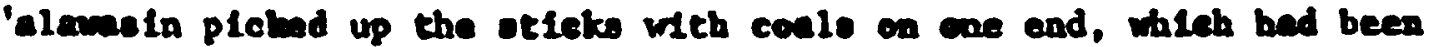
pleaed just in front of the tobatpo kurus, and ade the alge of the crose with then in front of the padrolen ind deer dancer. They went

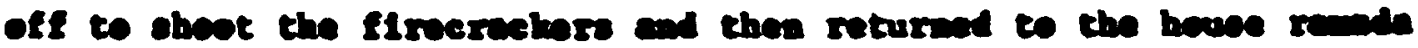

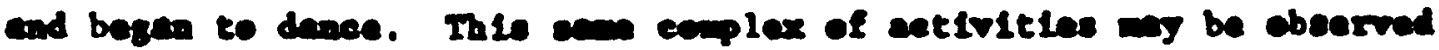

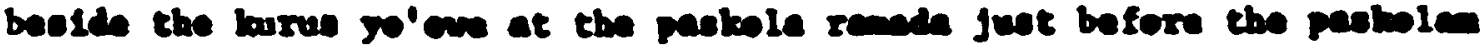




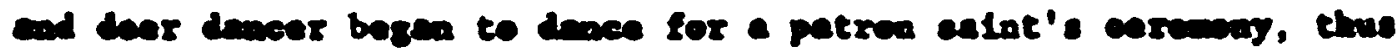

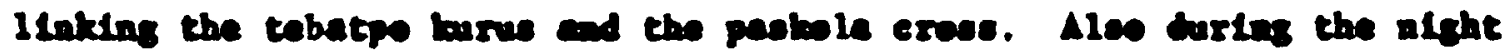

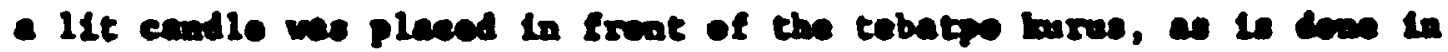

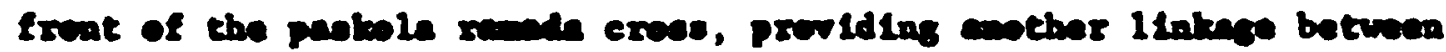
these two types of exosese.

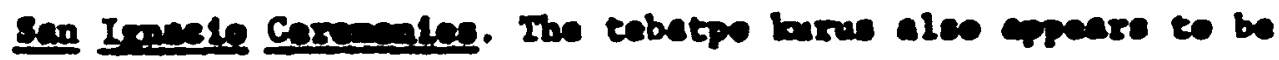

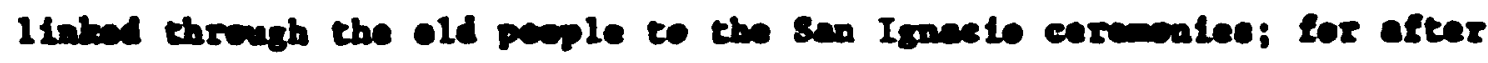

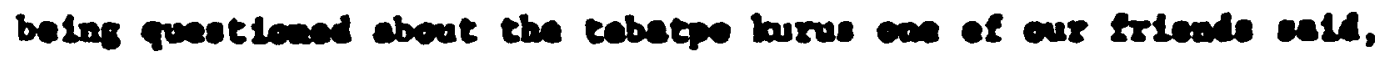

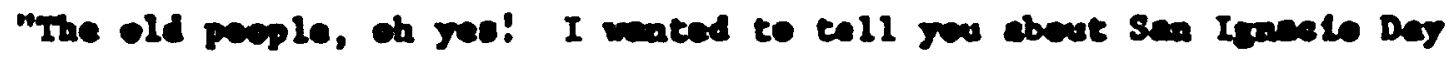
when the pasko perrecanoln bathe the feet of several old poeple."

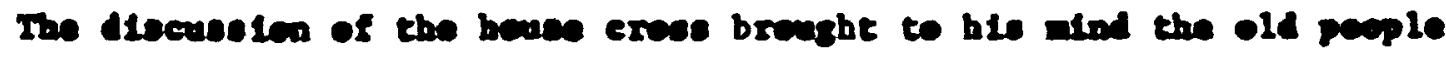

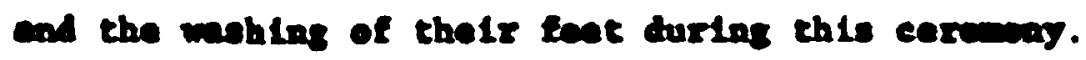

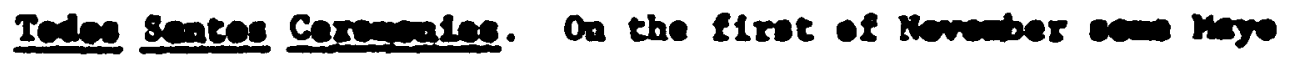

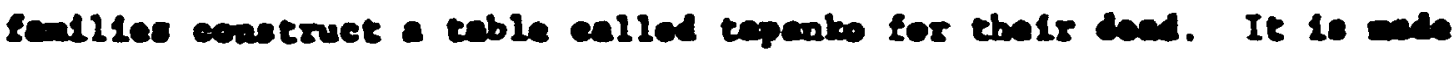

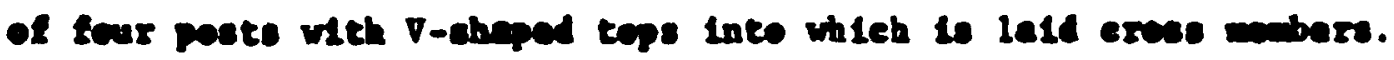
The table part is formad of pleces of carriso, a netive cease (Sptear 1940, Plate 12). The tepenteo to high, ebent ege lovel to a

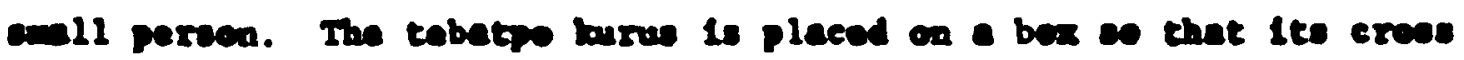
naber 1s abent at the table level. Then mater, food, and flomere for the doed are pleced on the table end wreatho are pleced ea the four posts. Sem of cur friteads invited us to so to the cemetery with them. They rewoved the Elemers, food, ead wreaths frem the tepento and we drove to the cametery, arriving gust ot duak. Wary peeple bed taben earth and weter and ade a paste wich they bal amothod over the Individanl grover, malng a amoth mound. They took the wreathe and

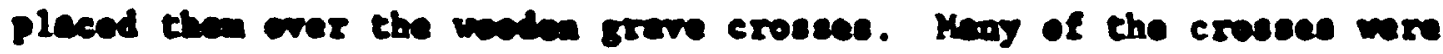


Ereshly pateted, and wo poticed that may of the childru's grove exweses cacund to be blue whorves chose of the chalte of this rery

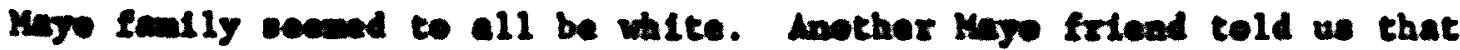

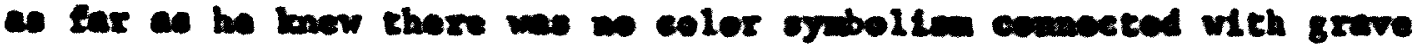
enveses, exept thet he folt a color such as sod or armage would be a ver bad celor for grove croseea.

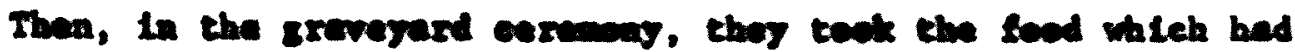
beas as the tepanke, and pleand it on the growes, took cendles and pleaed them all around the bave of the grove, end pourod water on the

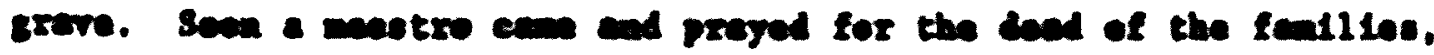

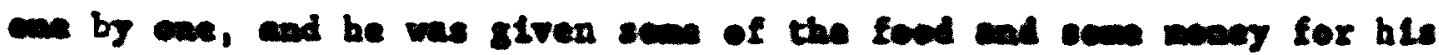

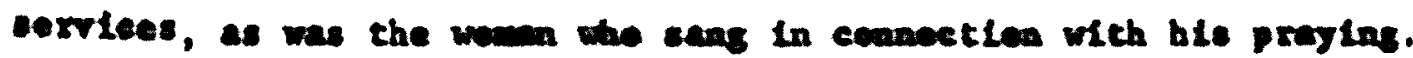
Wh retarned heme.

The tebetpe larue was linked to the cenctery crosees through belng

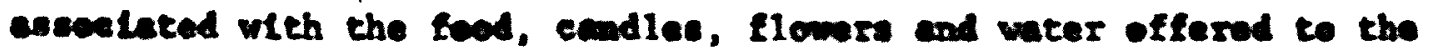
dan.

The Crees as Iten'AXnt. As our Fother, to be proyed to and to be confesed to, the tebatpo barus 1 inks to wote of the crosece used in

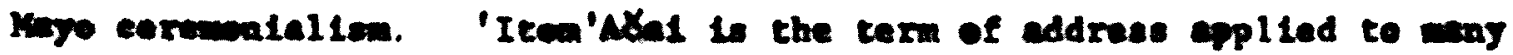
of the tebetpo burusin, the croeses of the kalbarto which ruas toward the river, the Inage of the Crecifixion, the sente knrus, as wil as te vant of the nale lmages of the church.

Praying to the tebetpo kurue also 1 inks it to all the lages, the

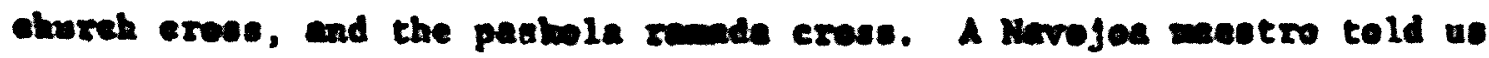
that the whele fontis ueed te pras in kaye by the tebatpo burus. He 
aded that in the pact it uead to rain a grvet canl but aow it reina ealy very lictle becuase usee hove given up proying to the tebatpe burnotu.

Whan Kayes ean to the church they flrot so to the ehureh exves to proy and then ceatime ca inte the chureh. As bee been ooted the

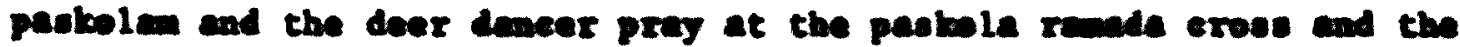

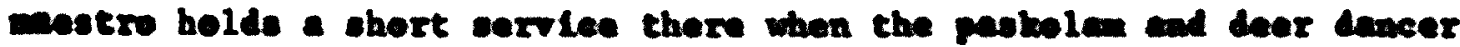

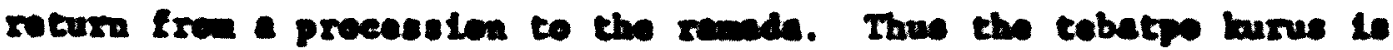

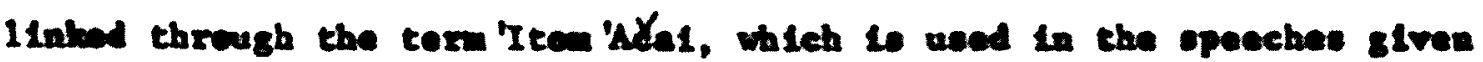
therr, and through the ectivity of proying to 1t, to the ehurah erven,

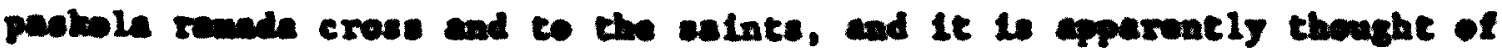
In weh the ene term as a boses or church ealot.

One often cenfesces to the exoes. Often at earwales on will

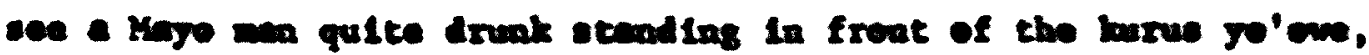

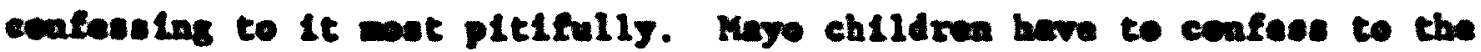

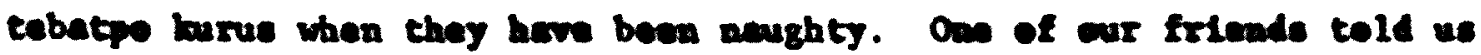
when kage chlldrea hed been bad repeatedly they were nover beaten but

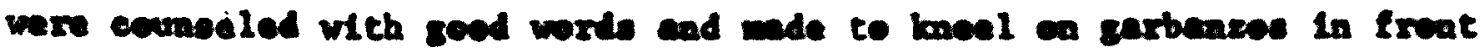
of the cebatpe burres.

On Sundrye the church exoss and bells as wil as the chureh seinte

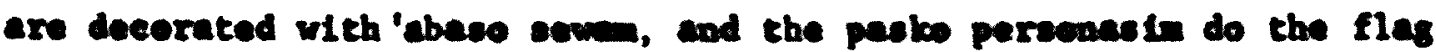
ritual in froat of the ehureh altar as they do in front of the tebatpo burus at a house cerweay. Thus It sew that the tobatpo burve and the ehureh burue go'on are elesely linked with the eatata, or are calnte in their an right.

This description and enalyele represents a frectlea of the mated 


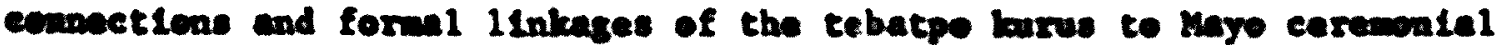

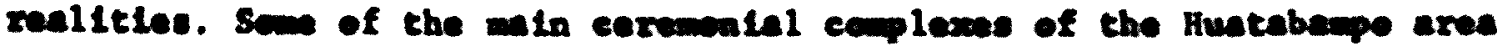

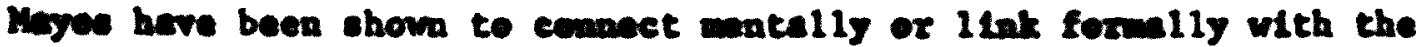

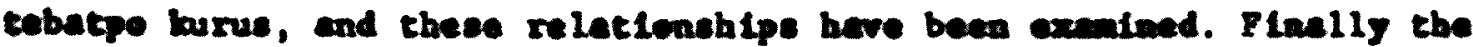
house erese as 'Item 'Abel to be prayed to and conleseed te has been

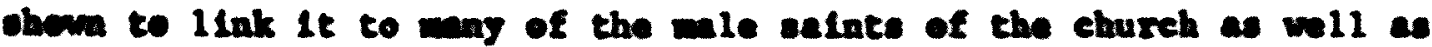
to tho ehurch and pastole rened crosses.

\section{The Tobntpe Kurus as en Inportent Lopect} In Severel Mayo OrIeatatian

Through the analyols of the formal linkegen and thought

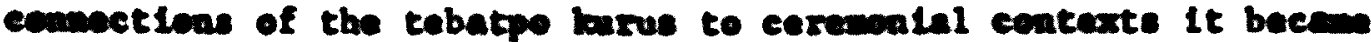
epparent that it aloo is en Impertent espect in ecveral Hayo orlentetleas. Beceuse the Mape culture is se oimllar to the Yequl the roder wy wh to refer to a discuseten of Yequl erlentetione by Spleer in Peten: A Yeart V1llare in Soeore (1954). I have netther treated all the erlentetlons he deceribes, chough I belleve then all to be rery luportont to Hayos, nor have I Ifnited ay discuselea to the ones be Introduced.

The old People. In Haye society the old people ere highly roopected, and so much tho gees into talking ebvat then and perforndag rituale concernod wth then, that it appeare to be a grest interest, if not an orientation. One of the firet questloas kayes esk Le, "Do you bave parente?" If cae has paronte he is Indead rich and if a housebold lecks old people it is very peor. As wave ean the tebatpo burue is IInked with the old poeple. When a eroes gete old it is not throme away but is respected and a new one is placed behlod 1t. Or ween the namers of a housebold get old a second or thixd creas an be pleced in 
the patio in order to guard the old poople and boep then from falling.

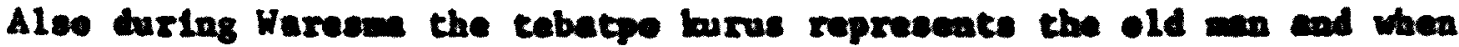

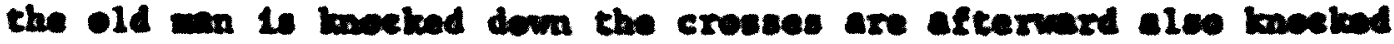
dow.

Cerveniel Leber. As am be ceen from an andatiog of the

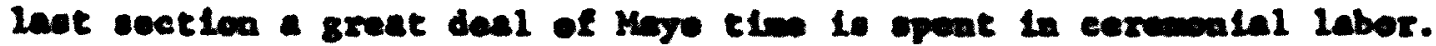

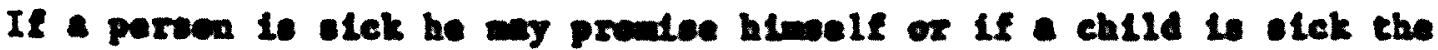

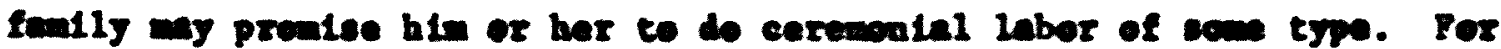

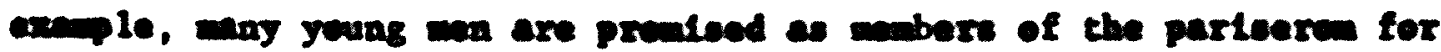

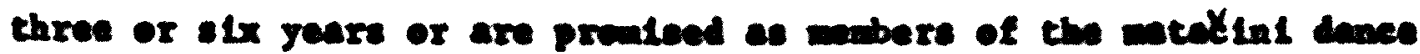

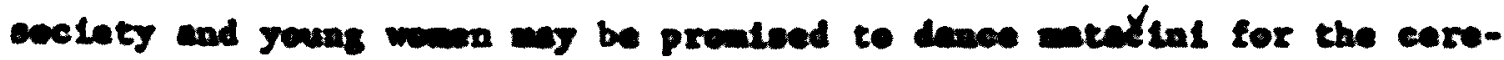
males of Bepiritu Sentu end Sentisin Tiniran. The tebetpo barus is

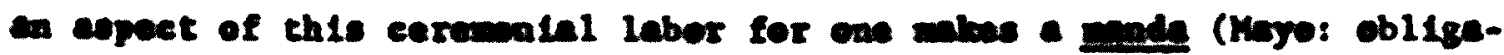
tory contract with a ealnt) to deorate his exoes for a eertaln ceenoloa.

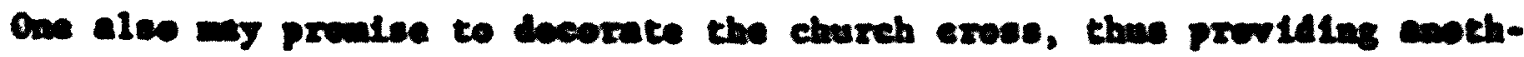
or linkage for wir study botmen the bouse crese and the church crove. The tubling of the tebatpe lurust en Coed Fridey epruine is

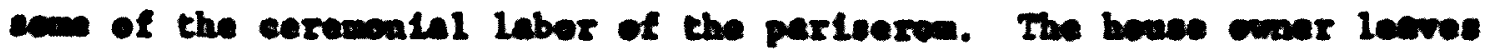

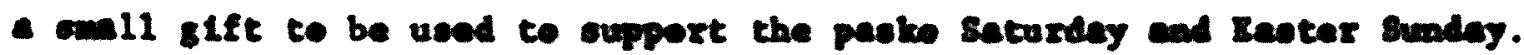

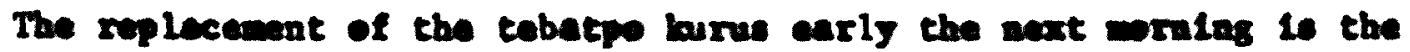

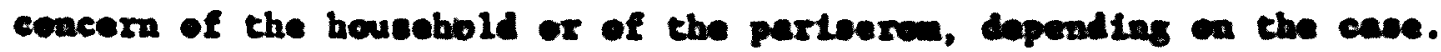
The Paplele Arte and Rele-Giving. The Mree enjos very weh the imelng and joktng of the pookole and som plen to etcend the elrat night of a pabto in orler to wateh tbe pabtolen before the large crumb of later nights form. As chown earlier in this study the cervony of the chooting of the firesnckers by the paokolen and the pragles by the 


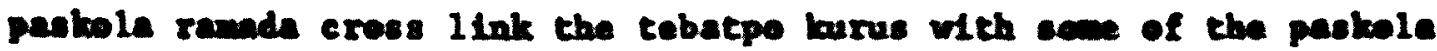
activities.

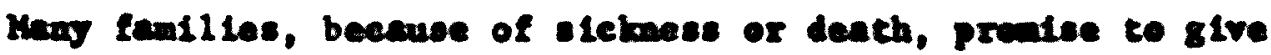
hewe cervionles. The paskele generally dance at chase pasken. As we here oboma, the tebatpe berus plays an ipportent part in thase

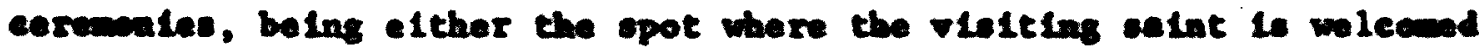
by the fandly or the aybolic tenb of the dand nober of the tanily.

Sunernatural Power. It is very difficult to collect informtion ch the bellefe and prectlees concerned with irteberaft and antive dectors. It is lonom, howner, that Hayes de belleve in witcheraft and that boalere of disenes belleved to be eaneed by witches do a gend business. The tebetpo burue fite in bere by functiening to

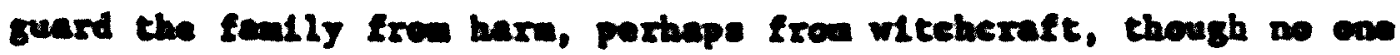

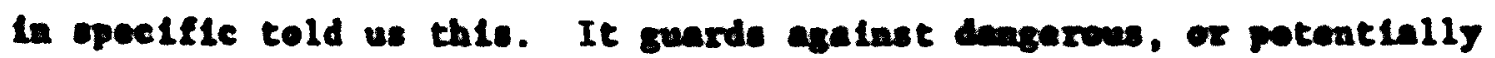
dangerves, poners leose at lont. In derylas that the hease crose protected in a specific wry fren witehes oas wa seld that it protects just an I carvd for and protected a truck. It is perthepe combat libe 11fe Insurance in the United states, where people sece to belleve that

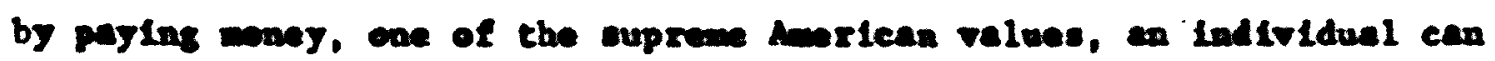
proloas iffe er at least wise the etlag of desth. The Hayos, lacking falth in mosey, plece a tebatpo burus in front of thelr houses for protectlea frea dangerous power or ponere and to bep thelr procteus old people Erem falling.

The Land and the Cult of the Dead. Another Kayo orientation or at least a great laterest is the land. While chatting with a Mayo 
the mention of or Interest in the land often protuces strong ontionel reactien on ble part. The land 10 eacred to kayos because his daed are burled there, fer one of many reseens, and he fears it ny be ealen from him.

The house cress is ipportent in the oriontetione or Incerese of the land and the cult of the coad. It is pleced in a Mayo's om

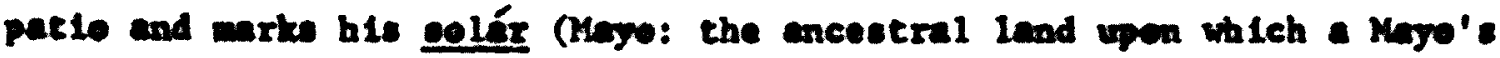
bouse is loceted). A comservative Myo w111 not leave the selar where h1s daed ancestors 1fved. In explanation of a refueal to wove Mayos often eay, "I have dead here." Thay add no wore, apparently feeling that anything wore would be eelf-obvicus. Thue we see that for Mayoe the bouse cross marke the coliar where the dead Iived and with which they are st111 ascociated.

Crosses also wark greves in the cemetery end other secred areas Imvolving the deed; for exaple crosses et kalbarlo symbolically mark the place where Chriet died. The burue yo'owe of the chureb is placed In the escred church pat10 and the pueblo crose marks the boundery of the pueble. Thus many types of crosese are linkad to the land through being placed in the ground et partlcularly secred opote.

The house erose alee is Important in the cult of the deed. A Mayo especielly needs a tabatpo burus twlce a year, during lent, when Christ is eymbolically killed and in November when the dead return, as well as any time a member of h1s fantly should d1e. The tebatpo burus and 1ts green bower represente the tomb of Christ or of the dead fanlly naber.

In November the tebatpo burue is pleced at one side of the 
tapanko upon which the food, water, and flowero for the dead are placed. In these ways the house cress plays an importent part in the orlentations or Interaste of the kayes in the land and the cult of the dend.

This andyele could be cerried on almot indefinitely, bewrver, the preceding discuselon seem suffielently leag to deneastrete that the house croos pleye a centrel part In Myo eeremealaliea and exlentarleas. 
VI. CORCLUSION

Th1e study began wth the prectleal questen, how cen an cutalder recognise a person as Mayo? In order to analyze the above question another question cam to alind, what does being Mayo asan to - Mayo? In secking anowers to these questione, a brief conclderation of Ingle Mayo charecteristice or ltem of culture revealo that wot of these factors, used a unqualified criteris, do not set Mayos apart from Maxicans. Many scholars have polnted out that items shared by two groups in contact will not provide a basis for distingulehing the greups. Eric Wolf, in the following quotation about the Indian in Mextco, has sumarized the problen (1960: 3):

How the Indian part of Maxican soclety 1s distingulahed from Ite wider merix has grat consequences for woet soclologleal anclyses of Mexico. Many Investigatore begin with a lint of tralts which are suppesed to charecterize the Indien. Yet upon exanination these trelte prove uneatiofactory. Reclal charecterletles are unsetiefectory beceuse man non-Indians exhlbit the phyelcal fectures deflned as 'Indian,' whlle some people who are clearly Indian In wey of 1ife are reclally Caucasold. Characteriestion by culture trafte derived from the pre-4lepanic past lo unsatisfactory because many pre-hispanic traito ouch a tortilies, metes, huereches, earepes, occur in both Indian and non-Indien comalties, and numerous clearly post-ilepenic trates such as oulnte' Images are uned In an Indian cultural context with no feelling of allenation or etrangenese.

Even characterization of the Indian eceter of Maxican soclety by language proves inadequate. There ere Spanloh-opeaking wonolingualo who Identify themselves at Indiens and are so Identifled by othera; for example, in the valley of Atlixco near the city of Puebla.

In a Lnllar veln, E.K. Francis states, "Thue the declelve point 
1s not what typleal gualitles are common to a group but that they are chared with no ether group within reach; that is to say, they function primarily as a dovice through which, in the process of pigeeaboling, me categery, or rather the Individuale In one cetegory, can be dietingulahed from those in mother category" (1951: 228).

When we turn to the question of whet being a Mayo mans to a Maye, It becomes obvicus that even though the Kayes obare the use of en Iten with Maxleans the maning of the Item and Its Integration as a syabel In the Mayo aymbol oysten of ethnic Identity is selden shared la the Maxicen naning and integration. Therefore In seeking an enower for the secend question, In attempting to see Mape ethale Identity frem the Mayo point of view, we discovered that two realen of mantag, Mayo and Morican, exlot for wany shared tralte. Thus one aspect of Mayo-nese Is the kinge mening of shared tratte and the integration of these traite as sybols in the Maye oroten of ethnic Identity. In understending thls Maye ayeter ene underatude the difference, for example, In a Maye's wearlog sondals and a Kaxtcan's maring eandele. Thls wy help to partially explatn Libby's ldea that "this feeling of ethnic Identity wa not dependent co any particuler anifestation of Chukehl culture, but that In part It we dependent on thefr an belief in 1t" (1960: 301). The Mayos, and perhaps the Chukchis, feel soes of the particular andfestations of their culture are isnificant in a distioctive may, or Chukch1, eysten of meanlnge. For the Mayos thelr culture is anlque and different from not only the Maxican culture, or cultures, but also frem the Yequl culture and frow other Indian cultures.

Th1: reallsetion st111 does not provlde eny sluple wethed for 
the outsider to Identify Mayes, but it does show that any atngle Item or group of ltem, in order to be ueeful in a sudy of ethnic identificetlon, wast be meningful in terms of the Mage oyetem of ethnic identity. Since many form of the cross seened fraught with maning for Mayos, Instences of It In the lives of the people of the Maye River Valley were cerefully observed and cacalogued inte classes. Through this excuinetion 16 was Indleated that the house cross we a unlque Mayo anifestation, when eceerpanled by o oystem of bellefs and coclal part lelpations.

The date from a general eurvey of the river valley were flrot enclyzed to see $1 f$ dense arene of house crosees corrsleted with the presence of Mays cermoniel centers, wich we in fect ohown to be the case. Next the foullies we knew well ware anelgzed shoulng thet the wterial woilth of the fantly bas very little correlation with the existence of a tebatpo larus and coaveraely showing that haje sectal participation and cultural behavior corrolete with the existence of a hwace erese In the grwand of the petio. And finclig the ceromoatel contexts, functlons and 1 Intages of the house erose were dlecused in order to attain some ldas of the Moyo maning of the house crose and of 1te Integration In Mayo $11 f e$.

As we noted earlier, Sibley etates chat the flesta for the patroa selnt of the PhIltppine village is o echenien atding in the mintenance of v1l1age Ldent1ty (1960: 508). Th1s ts true for Mayos also. In addition te mentelning village Identity Hayo patroa caint ceremonles also relaferee Yayo tribel Ident1ty. For example Individualo from the Fuerte River Valley were lonewn to be paobo parsonesten at 
Jupart in 1961. In the realizatien of the ceramosy Howe see Instances

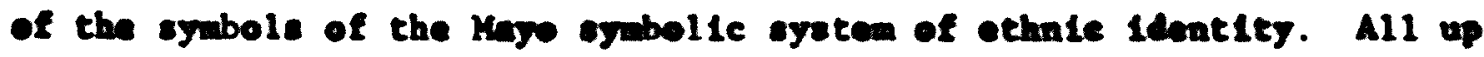
and dewn the river velley they see thelr tobetpe burustin pulled up and loyed in "tombs" of bewers when Christ is aymbelienlly eruelfled, oce the sam type of bomer nde over the houes cresees rhon a nober of thelr foully hes died, and sea whte flowere en the tobetpo burualn the day of the Sante Kexwe. During a cerwasy at Juparl arvand the church, at the paskole remada, and at the cooklng ramada Moyeo hear metly Mayo opoken and see caly enndale worn by other Majos. Thwe the

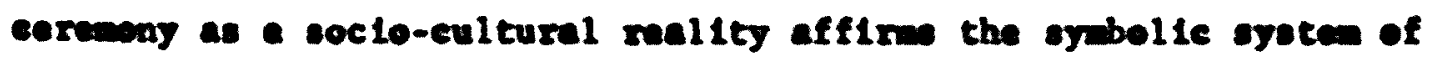
ethnie Identity.

I should like te return te the 1dee, which wa cuggested early In thls paper, that Mayo ethnie Identity is perhepe no wore then elpiy the poor end of a ceatimum frem walch to poverty. Hoves are, in fact,

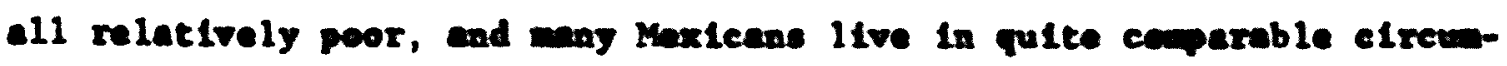
stances. However, In term of a smbolle ogoten of ethnic ldontity or

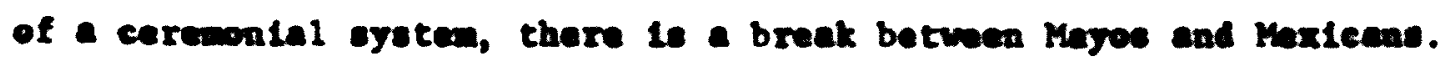
Thls is not to say thet there are not peoplo whe are wore Naye or $10 e$ Maye, wre Maxicen or lase Kartean. It appears that thore are two

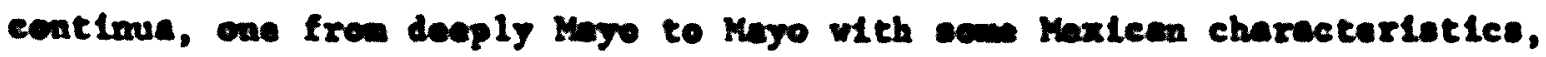

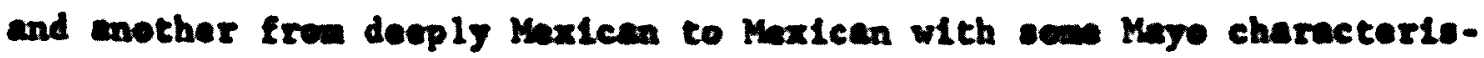
t1es. The Mayo-Mextean and Mexicen-Hayo onde ere the nost difficult to analyze for tralte are often ohered between these groupe. Persene In these areas wa switch from one to the other, gelng in elther direction during different perted of their lives, wing the eltuetien additionally comlex for the andyet. 
I have not attempted to plot the complete oystes of Maye ethale 1dentity. Thls would ropulro loas and tntimete atudy and revid tale a student inte reales of koye eulture such as curing and witcheraft, anas othera. Alee a cepplete otudy of the nature of the Integration of the tull set of aybols in the echnic Identity oreten alght ruveal the mehanisw of Integration sore fully thea I have been able to do in

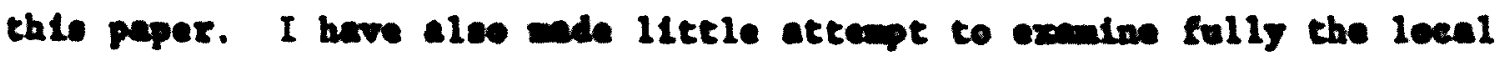

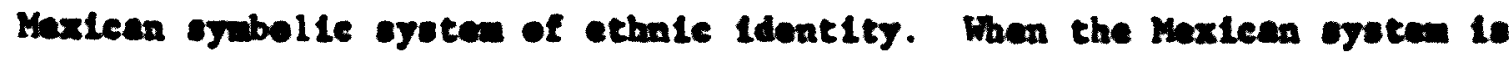
andyeed it w111 then be poselble to compre and centrast the kayo and Maxlean ogetem. were fully and wore eccurately.

Another problem which could be profitebly studiad in the ringe River Valley is that of intergroup problew and the reduction of seclal conflict betweon ethnic groupe. The naterial derived from the compartson suggeeted in the proceding paragraph alght prove useful in a otudy of this nature. Robln Willina in his monograph The Reductlen of

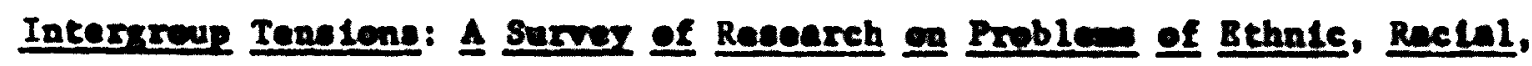
and Rel1gleue Groug Reletleas (1947) dLscusees the pregrams and studles concerned with thls problem that hove alroady been eet up. He alee ouggente poesblittles for resenteh, anelyzen research appresches and teahnigues, and includes on extensive blbllegrephy.

The question of differsat typee of ethnic identity should aloo prove to be a frulteful etudy. The Myso type of eymbelle aystem of ethnic Identity is found In e culture whlch is very tightly lntegrated. Weald ethnic ldentity roly upe some different type of eyeten in a lese tightly Integrated eulture? Do conditiens of contect affect the type of ejoten of ethnic Identity that a group crentes? 
Other Maxican Indien cultures appear to hove web in comon with Mayo eulture so that a hypotbetical Latin Anerican type of ethale ldentity syeten might be formaleted. For exnmle the conditions of ethnle group contect desertbed by Colby and van den Berghe for the ZInacanten Indiens and Sen CrLetobal ledinoe in the bighlends of Chlepa (1961) are quite ofllax te Mayo River Valley cenditions. Concerning rece they flad the caw condition an we be described for Mayos, etating that (1961: 774), "Raclallem... Le eltber completely absent, or present in such an atteauled form as to be unrecognisable. The distinction betwen ladinos and Indians is cultural racher then rectal." They eleo flad kInde of horlzontal etructure of coelal

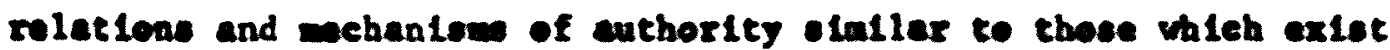
for Mryee, explelning as fellew (1961: 774):

Wh1le ledino culture is verticelly structured and stresese competition and comand-and-obey relations, Indian culture is bestenlly hortzontal. In opite of the importenes of ege and of rlgid etiquette besed on relative age of the participants, Indien culture deemphesizen coelal hiererehy. Autbority is exarcleed through persuasion and influones rathor than through comands.

Colby and ran den Berghe polnt out that Sen Crlotebal IndLens difer erem Indlans in Quesaltenange, Cuatemale, In that the latter

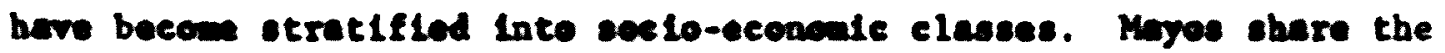
tratt of nea-stratifiention of this type with the Indians of Sen Crlstobel. Colby and van den Berghe ettribute this differanee to the fact that in San Cristobal the Indians wy "paes Inte the ladino group upon ecquiring ladine culture and langunge, wheren in Quetraltenango they rarely do se" (1961: 787). Thelr bypotheele for explaintng this refuesl of the ledino group to adntt Indians is 
the lack of Guatemalan geverwantel Intervention, unt11 1944, In fevor of IndLens. On the other hand, suce the Mexlean Revolution in 1910 through 1917, the Mexicen govermant hes Introduced reform in favor of Indians. If this hypothesis is correct, then barring any other variables, sovermant latervention may provide a partial explanation of Mayo Valley and ChLapas HIghlend perallele In Interethnic relations. Specifle conditione of contect way then alter ethnic Identity; for exaple, Mayos belleve that farning and working as peons is the proper Maye wy te earn a living. However, In Quesaltenange Indlans are not only forwers or peons but may becone benk clerks and wechenles while st1ll being ldentifled as and Identifying themelves as IndLans.

Edward Brumer analyzes urbanlzatioa and ethnle Ident1ty In North Suntra and gives the reader a pleture of the Tobe Batak culture whlch Io highly Integrated around the concept of adat (the "custon," kinchlp and ceremonial duties as percelved by Tobe Batak Individuals) (1961: 508-20). It appeare that a sybol gysten of ethnic Ident 1ty has been mintained between the origlanl village end lte mobers in the 61Ey. Th1s 1s also somewhat the case for Huataberpo Mayos; howrer, the distance 10 weh shorter from Huatabapo to Juparl than frea the Indonesten village to the clty. Sone Huetabempo Mayes go to Jupar1, where they heve compadres, for cerenonlel perfermances.

The Mennonlte comantt1es studled by E.R. Francle (1947, 1948, and 1955) hove parallele to Mayo and Toba Batak comanit 1es. In the past all three socleties created a diotinctive soclo-political oystem which wa tightly integrated with a religlous oyetem. Aopecte of the culture wre ade eacred and a syobol system of ethnic Identity was 
devised. As the centact eltuation cheaged, for exmeple as Mexico, Canade, and Indoaesta took over mech of the polltical control of echnic groupe in thalr territeorlee, blocks of the cultures were nodl110d. But the concept of ethaic Identity romined in the onall 8ruape. Perhaps all these cases could be connidered nubers of ene type of ethnic Ldentity eyetem with several eub-types, Latin Anerican, Allan, and Eurepen.

Other types of system of ethnic ldontity eleo exlet, for example, the ethnie groupe Warner and Srole deceribe In the third volum of The Yenlee Clty Serles. The Seclel Syeten of Anericen Ethnie Groupe (1945) and the Untted States Indian ethnic group deceribed by LLe Peattle in "Belng a Megackle. IndLan" (N.D.). Werner and Srole disouse minorlty groups ereeted in a New England elty by thatgrante cening to the United States a Individuale rather then a a group, as did the Hannonites. The ethnic 1dentity of these groupe we then ereated as mach by the out-group as by the In-group. Son groupe do not share a great deal of culture but shere other attributes suoh as reclal characteristles and thus are luped together by the cut-group.

It wy be of importance to note that Hesquakle eulture wo Integroted a bit differently then the More, Mennenite, and Tobe Betak eultures. Some of Mequakte ethnic Idantity, Indlem-noss, seom to be patternod after and to conform with, in some reapecte, the out-group's Inge of Inden-nose. Thle certalniy is fer from the cemplete case, for

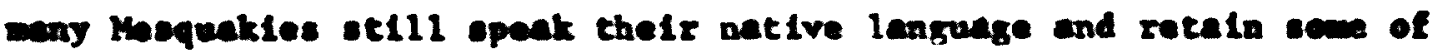
the old culture. Pestete saye concerning the Mesquakles' wearing of fecther beaddreabes and etending beelde tiplo in order to erecte a 
ohew for the Aaglo-Amerlean, thoy plos the part wo wil they are beglaning to belleve thet theoe ltem are truly frem thelr past. Thus a coneept of IndLen-nese on the part of the cot-group is belng Integratad Inte a Maquakle oyetem of ethnic ldontity. Thle procese In the Mequalie ethnic Identity oyeten is also taking place with respect to oymbels and rel1glous coplares of other Indina tribes. For exreple,

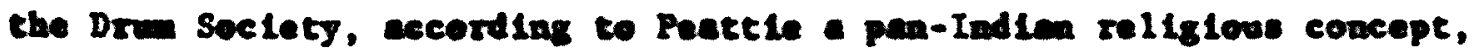
we secepted by som of the Naguakle yeare age. The oristonl vision

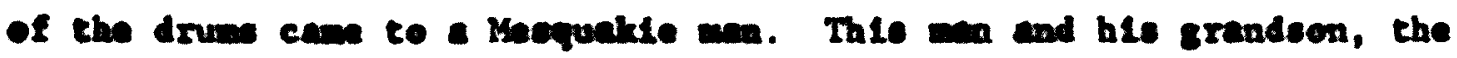
erwop's later leeder, were wen whe were proud of the Indias reilgion and the "Indlan Way". They than Integrated thts cot-group Indian cencept into Hequakie culture ead it took ca Hesteakle neaninge. In chese wase both Anglo-Amerteen and otber Indlen tribes' concepts have been Integrated into a Mopuckle egeten of ethale Identity.

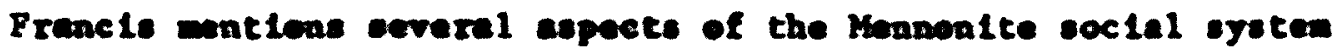
of 1870 which set le off as an ethnic group (1948: 105). It is interestIng that both the Mayo and Magquakia syotem Inelude tbese aspecte. AII three groupe, Mennonites, Mayes, and Mesquakles, have a comon Interest In their righte as ethnic groups, a bowogeneous cemanity, InsteutlonalIxed sectal behavior, a coasietent culture pattern, a tendency towerd ethnic group endogany, and a folk dislect or dietlnetlve languge. Thus the Maquakies, as well as the wayee and Hanninltes sre an ethnic group with thelr own oyeter of ethnic ldentity.

Seme differences do seen to exlet betwen the Masquakle sybol ejeten of ethalc 1deatity and the rayo type of ejoten. These differences appear to concern the integration of the eyoten itself. 


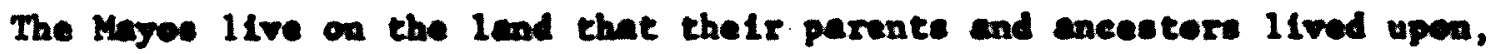
wherene the Mequakies have relatively recently purebaed the land upon which they 1ive. Oa seceunt of this histerieal ifference, the aybol of the land has a web different maning and Integration in

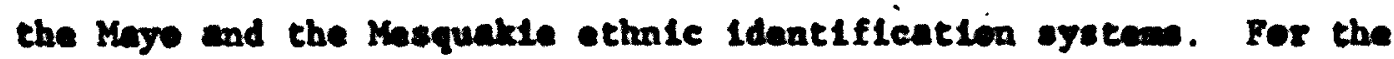

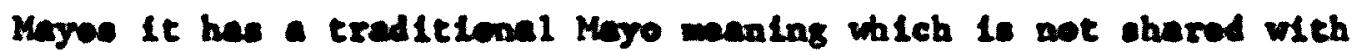

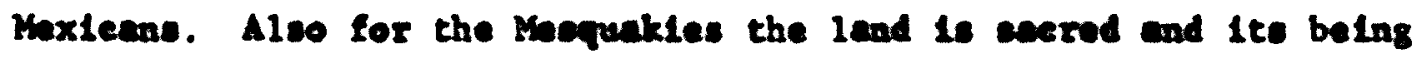
ccomannily held to a eymbel of the Kasquakle as a group egatnet all otber groupe. But they also ralles that the land can be bought and

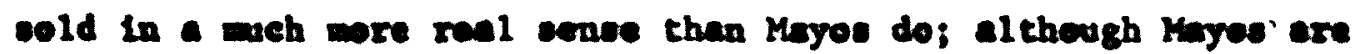
were of the pattern they expect It of Maxieand, not of thandived. This cencept of the Maspatsles of themselves as londowners is a concept wore In Iine with that of the larger eociety with which they are in contenet, partape.

The osw sort of differmee in incegratien potterne at be polnted up in other exples. A flas olnilar to the kexicen fleg is

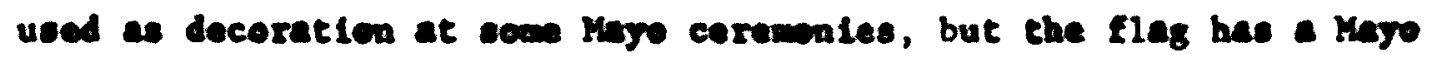
maning rather then a Maxicen one, for woot partictpente. The flas a a ogabol is Integrated within Mayo culture, rather then Integrating Maso culture wth other Mexten Indian cultures or with Mexicen culture.

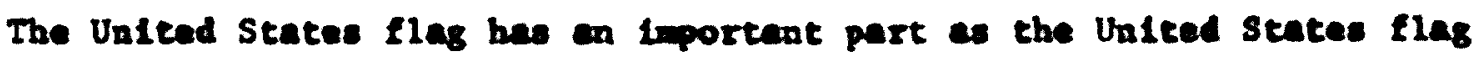
In the Indian cerewony of the drum. According to Masquakte myth the flas we flrst planted on the dance grounds by United States coldera. When this teok place the Indiens knew thet they and the Anglo-Amerleans would be friends. The flag has been Integrated late Mesquakle 
ceromonlalion and carries a dietinctly Mesquakie maning. Also it Integretes keguakle wth other IndLans and symblises a link of frlendohlp betwen Anglo-Anerlesas and Indlane. Thes seas difference in types of Integration in Mago and Maguakie ogmbol syetem of athnic Ident1ty does exist. The kayo type of Integretion Ilnke many oymbels wth Llstinctig Hayo maninge and sets Majo ethnic Identity opart from the rest of the world. Sintlerly Masuakle type of Lntegration 1 inke

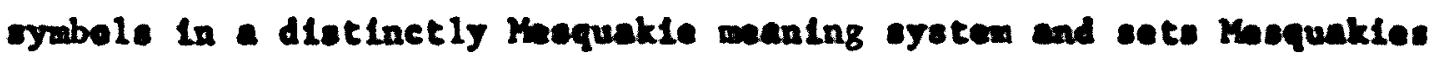
apart from the rest of the wrid. On the other hand the racquakle type of Integratien aleo 1 inke Mequakle symbels with other Indian cultures of the United States and with Anglo-Americen culture.

In oumary, Mayo ethnic Identity is based on oymols unlquely Integrated. One of these symbols is the heuse cross and its asceleted patterne. In diecribing knjo ethnic Identity, this symbel was firet observed in its aspects of phyelcal reallty and then it was correleted with May acclel participation and cultural bebavior. Finally ite dietribution in Mayo cervenial and belief syotene wa ennlysed. Through the consideratica of the house crose as a sybel in the Maye ethnic Idantity syotem wo beesm acqualnted with case ethnie identity eyotem. The suggestien wes then Intreduced that Myse ethnic ldentity we a naber of a type of gybelic syotem of ethnic ldent1ty. The ethnic Ldentity oysteme of severel groups, Toba Batak, Manaealte, Meequak1e, and "Yanke C1ty" mere examed, comparnd, and centrested wth the Mayo eysten, revulting in the centative propoeing of trpes of ejotema, a Majo, Toba Bacek, Memoonlte type, "Yanlese City" minority 
type, and a third type represented by the Mesquakie, which should pertheps be called an inter-egreten type. The criterion of cultural Integration within the ethnic Identity oystem and between systen In centact we ouggested as a typological basis. Many of the symbels in the Myso type of aratem are Integrated relativeis more within the oystem Itself; wervas, in the Masquakie type of eyoten, the syabels are Integrated both within the mstem and function also as mehnulaw for the integration of the oystem with out-group syaten of ethaic Idontity. It should be ephesized that this distinction between the types of ethnic identity oystem is not ebsolute. Pexhape it muld be mere maningful to think of the systems of ethnic Identity as dLtributed along a continuum besed upen the degres of Inter-system and Intra-systen Integration. 
NOTES

1 Paskone, or packe parsoasein, (Mago), is tranclated flecteres In Spanlob. Sptcer elected to use the term flecteros noet frequently In Poten: A Yequi V111ene In Sonore (1954: 72-77). The Kayo flecteroe, or pasteme, have very oinllar overall comandty functions to their counterparts in Poten, wth reopect to participation in funerals, and at certein eeasons of the year, In the $1 \mathrm{x}$ respective patron saints' cerrenontes, as wil as hom eercuontes of varlous klade and regular Sunday kont.

2 The deer and pablele arts of the Mayes are efmllar to thoee of the Yequis (Sp1cer 1940: 173-203).

3 For Tucson, Artrena, Yequis, Splcer bes polnted out that the heuse croes Ilake with way other espects of Yequi Ilfe, ouch as the enculturation of chlldren (1940:88), cerewonlal eponsoroh1p (1940: 96-97), and heusebeld ceremonles (1940: 183, 191, 225).

4 spicer also mentean the church erose as a feature of Yequi churches In Tucson, Artzone (1940: 225), In Poten, Sowora (1954: 80), and of Yequl churehes in general (1958: 435).

Syegul pakkola ranges also hove thls type of eroes (Spleer 1940: 225). 


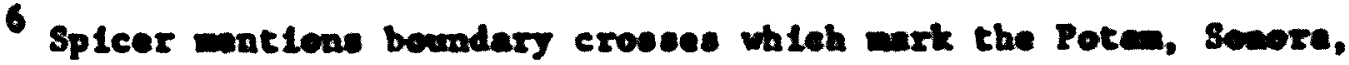
territory. "On thle soad, son five alles east of the r111age, there are three large moden crosece mich are belleved to be lecated in a apot where Jesult prleste flret pleced three sinller erosece. They are regarded as enting the eantern boundary of Poten territory. Alous the som read about a mile en the other olde of the village there are three other crosece wriks the wetern boundary" (1954: 12).

7 Bealo wotlow enother poselble variatien in type of the bouse erves thlch we did not cbeerve. "The ene erves I sen which we

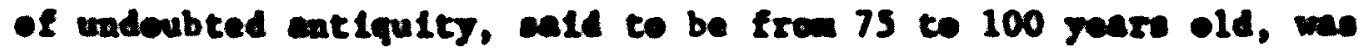
nearly 9 leet blgh vith som serollwork orwmentetion earved on It (p1. 6. 218.1)" (1945: 19-20).

8 The burus go'eme of the church in Sen Ignecto is double. A new croes etande jost bohted the old eas. This church hes old wile and the second creas, we wre teld, we pleced to boep the mill from falling.

9 The full ippect of the Kayo verb letis, translated here as "to forget," Is not carried in the English. The woye is a etronger wrd than the Englieh, horlag connotatlons of a dengervus coadition of dismopect wth regerd to cerweniel obligatlene, eopelally to the cand, pertheps.

10 Here, near the creas, the Juparl image of San Juan is beptized in the river esch rear. Aleo, at this opot, the santis

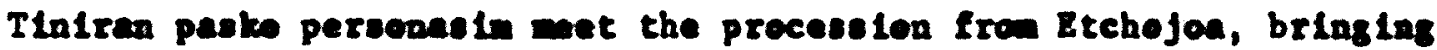


the patron of Etchojoe to Jupar1 for the Santisina Tiniran ceremonies; and leter In the year, the Jupari pasko personasim again weet a proces* bion from Navowaxia by this cress, this one bringing the lmage of Guadalupe to the cerenony for the new flag of the Santisima Tiniran, and vistting Guadalupe In Jupari.

11 The Terabume Ind1ane, who 1170 east of the Kayos, alve have secred patios with crosese placed on the eastern edge of the patio (Bennatt 1935: 269-70; Plancarte 1954: 49-50). Foth Bennett and Plapcarte glve ofiliar wanings for the four directlons assoclated with the patio. Bast is the direction of the gate on the other side of which Christ we born, or through which be entered the world. West lo the direction of death. South is the directien of the virgin of Guadalupe or sem other ealnt. Nerth is the diroctien of the soveraore and officials. One Maje fanlly in Jupari wa noted to hove thelr crose pleced on the north side of the house. No moaning wes obtalnod for this plecenent, but $w$ hypothesis is that the positien of the crose way have indicated certaln soclo-political particlpations of fonily nobere. Plancarte also notes that soue fanilles do not have crosses in thelr patlo all jear but only place then there et the tire of a ceremony (1954: 49). So it is poselble that not leaving one's tebetpo kurus up all gear is an old Mayo pattern also, and to not en Indication of cultural loss on the part of the Mayo fanlly which pleces their crose In their patio only during Lent or at the time of a house cerenony.

12 Sples mentions thls same contrast of settlement patterns for Sonoran Yaqul communitles (1961: 71-2): 
It we obvlous, howrver, that... two different eettlement patterne were competing. The old plen of fenced houcholde irxegularly elustered in the vicinity of a church we in part reallsed, but at the som tim portions of the comulteles wre lald out in a grid plen vith howses flush with the etrecte and

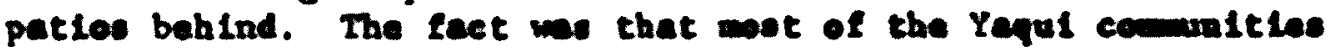
had two civic centere, we the church and the hodquertere of the civ1l gevernors and the other the Maxican any headyuarters, - federal rural sehoel, enll storee, belwerlee, and pertupe $a$ poel hall. Around the latter, houses were placed is the firtcan vay, areand the church in the elder Yagul way (1961: 71).

13 Thls type of bed 18 detinctive to Kayos in this area and deserves a deseription. It is compoed of a atple moden frum crisecrosect with etrips of hide over which a cane nat is throun, in plece of slats and antrese. The fram is fastened tegether, not wth wet belte or nalls, but with a square tongue on coe maber fitted into a equare hole abeut in the center and of the other nomber.

\section{Pabke Le Maye term which alght be translated fleste in}

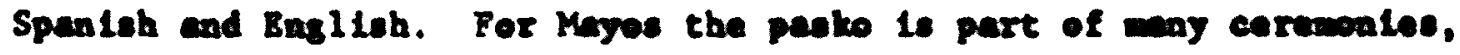
hewover it does not include the alne days of preser before a selat's Ly or other appects of a complete Maje cercumay. I hove hesitated to uee eltber term for a total Kaye ceremony oven theugh parte of nany ceremontee could edequately be decerlbed by the terms. Aleo, encular ceanotations of the Spanish tern, fleste, have led we to ovold uslas it.

15 For more Informelea on Mexican dances in tho aroe see Eraemis' book, Mon Iatee Ceatrel (1961: 243-44).

16 Kayo monolinguallen occure amoag young people, although seme - there opeak Spaniob wre of the tim than do their parento. In a few fanlltes we knew, the geung pople and chlldren ware monoliagual in 
Mayo, and In others the chIldren spoke Mayo well even though their perente mare bllingual. In et11l others, chlidren spoke only Spentok.

17 Splcer finde that for Tucoon, Artzone, Yequis, the househole erose as well as the Holy Crose my be called "Our Mother" (Yequl: 'Item 'As). Thls tern "...1s applied to wooden crosese about which ceremonles center In frent of the church or bousehold, to elaberately flowered cresece honored on the third of May, to Images of the VIrgln of Guadalupe, and to various other manifestations of the VIrgin." He also Flnde this to be true In Petan, Sonora, where Yaquis apply the term las (Yequ1: erose) wot frequently to the houseyerd and alter croses, but 1 see cell both erosees "Item As, Our Mother" (1958: 436). Splcer elvo rolates the Yaqui wyth "In whlch $1 t$ lo told that Mary -- Our Mother -turned herself into the troe which was ande Into the crose on which Jesus wa eruelfled, so that he wa held protectively in her arms during hle last agony" (1958:436). This term, 'Iton'Are (Mayo: Our Mother), nay be used by Mayos for the house cross et tlwes, but I do not know of any single case. When arked, Mayos say the house crose is 'Item 'NClat. It 18 possible that the type of house cross shom in Figure 10 is Identifled with 'Itom 'Aye, hovever, no Mayo ever Idmtified it as such in my presence. I have seen dressed crosese In the keys country, but they appeared to be dreseed as meles rather than famlas, and when prayed to they were addressed as "Itom 'Alal." For Mayoe the Holy Cross is also 'Item 'AXal, eccording to wost of the poople we knew. Oaly on one oceselos did we hear people talk about the 
Holy Crose in connection with 'Itom 'Aye, and this was at the September cerremony of the Santa Ruxus. An old man sald, "You have Just eeen the

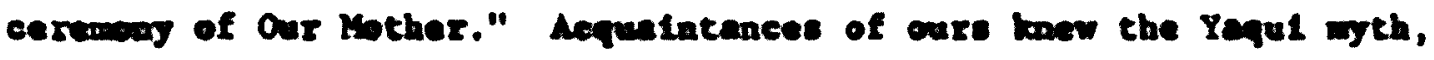
but wene would adnit it we Mayo, or discuse it further. It wa be eenjectured as to whether this alfference in expents on the term applied to the varleus forms of the cross represents a hasic and lengctending difference between Yequl and Mayo bellef cystems or whether te represente a late Maye change or a late Yaqu1 change.

18

In Roman Cacholie churches throughout the world the way of the croes to performed durtag Lent. 
REFERENCES CITED

ACOSTA, ROBERTO

1941 Aputes Hicterlcos Sonorenses: Lo Cengulete Tengerel I Eepleftual del Yequl and del Myo. Msxieo, Imprenta Aldina.

BEALS, RALPH L.

1945 The Centeaporars Culture of the cáhlte IndLane. Bureou of American Ethoelogs. Bulletin 142.

BENNETT, WENDEL C. and ROBERT M. ZINGG

1935 The Terahunere: An IndLen Tribe of Nerthern Mexico. Univerelty of Chicage Prese.

BRURER, EDWAND $\mathrm{M}$.

1961 Urbagizetien and Etbnie Identity in North Suantre. Anrien Anthrenlestet 63: 508-21.

COLBY, BEIUAMIN N. and PIERRE VAN DEN BERGLE

1961 Bthnic Relatlons in Seuthosctern Maxice. Amrteen Anthrepelos Let 63: 772-92.

CRULRINB, LMNRE 5 .

1961 The Phowolowy of Arizon Yequl, with Texte. Anthropologicel Pepers of the Untversity of Arisons, Number 5 . Tuesea, Univera Ity of Arisen Prese.

BRASTUS, CHARIES J.

1961 Yan Tabes Coatrol. Cultural Develconte and Anerican Ald. Untrerelty of MLneseten Prose.

FLEURY, GEORGE

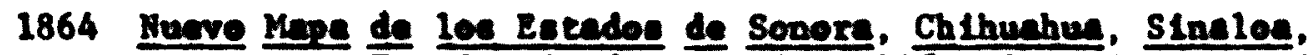
Durane, $y$ Territerle de le Bale Callfornia. San Francieco, A. Gansens. 
FRANCIS, E.K.

1947 The Nature of the Behnic Group. The Anericen Journal of Soclolory 52: 393-400.

1948 The Ruesien Mennonites: From Rellglous co Ethnie Group. The Aserican Jeural of Soc1olosy 54: 101-7.

1951 MInority Groups-A Revision of Concepes. The Britleh Journal of Soclologr 11: $219-30$.

1955 In Search of Utopla: The Kenoonltes In Manltobe. Glencoe, The Free Prese.

GENTRY, HOHARD SCOTT

1942 Rlo Mayo Plante: A Study of the Flora and Vegetation of the Valley of the Rle Maye, Sonora. Carnesie Inetcution of Wesbington Publicetion 527.

GILL, MARIO

1957 La Congulece Del Valle Del Puerte. Móxico, ITH., S.A. LIBBY, DOROTHY

1960 Three Hundred Years of Chukchl Bthnic Ident1ty. In Men and Cultures, edtted by Anthoay Hallece, Pp. 298-304. Univeratity of Penanglvania Prese.

OBREGON, ALVARO

1961 Qcho M11 K1loestros en Ceneañ. Mérice, Fundo de Cultural Bcovonice.

PRINTER, MURIEL THAYBR

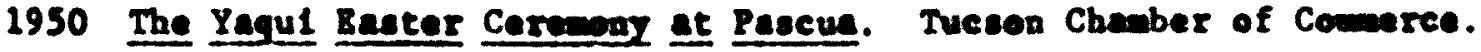

1960 Easter et Pescue V11lage. Univerelty ef Arizone Prese. PEATTIE, LISA

N.D. "Belng a Kesquakle IndLan". MS, atmegraphed, Untverslty of Chleago.

PLANCARTE, FRANCISCO $\mathrm{M}$.

$1954 \mathrm{BI}$ Problema Tarabunara. Meorles Del Instituto Nacional Indigentete, Volumen 5. Meleo, Ediclones Del Instituto Nacional Indiginlste. 
READ, IIFBEIT

1955 Icon and Idea. Harvard University Preas.

REYES, JOSE SOSA

1957 Aspectos Fisicos. In Proyecto De Programa De Gobierno Del Eatado De Sonora,pp.29-39. MExico, Impresiones Modernas, $\overline{\text { S.A. }}$.

SIBLEY, WILLIS E.

1960 The Maintenance of Unity and Distinctiveness by a Philippine Village. In Men and Cultures, edited by Anthony Wallace, pp. 506-12. University of Penneylrania Press.

SPICFR, EDWARD H.

1940 Pascua, A Yaqui Village in Arizona. Univeraity of Chicago Presa.

1943 Iinguistic Aspects of Yaqui Acculturation. American Anthropologist 45:410-26.

1945 Potam, A Yaqui Village in Sonora. American Anthropological Association, Memoir Number 77.

1958 Social Structure and Cultural Process in Yaqui Religious Acculturation. American Antlropologist 60: 433-41.

1961 Yaqui. In Perspectives in Mmerican Indian Culture Change, edited by ז.H. Spicer, pp. 7-93. University of Chicago Presa.

TARNER, W. LLOYD and LFO SROLE

1945 The Social Systems of American Ethnic Groups. Yale

WILLIAMS JR., ROBIN M.

1947 The Reduction of Intergroup Tensions: A Survey of Research on Problems of Ethnic, Racial, and Religiou froup Relations. Social Science Research Council, Bulletin 57. New York.

WOLF, ERIC

1960 The Indian In Mexican Society. Alpha Kappa Deltan: $\Lambda$ Sociological Journal, Special Issue the Social Anthropologs of Middle Nmerica, Vol. XXX, winter, Number 1, pp. 3-6. Published by the United Chapters of the Alpha Kappa Delta National Sociological Ilonor Societs. 